\title{
The effect of resident attitudes, social capital, and stakeholder engagement on rural tourism development in West Virginia.
}

\author{
Doug Arbogast \\ West Virginia University, Douglas.Arbogast@mail.wvu.edu
}

Follow this and additional works at: https://researchrepository.wvu.edu/etd

\section{Recommended Citation}

Arbogast, Doug, "The effect of resident attitudes, social capital, and stakeholder engagement on rural tourism development in West Virginia." (2019). Graduate Theses, Dissertations, and Problem Reports. 3811.

https://researchrepository.wvu.edu/etd/3811

This Dissertation is protected by copyright and/or related rights. It has been brought to you by the The Research Repository @ WVU with permission from the rights-holder(s). You are free to use this Dissertation in any way that is permitted by the copyright and related rights legislation that applies to your use. For other uses you must obtain permission from the rights-holder(s) directly, unless additional rights are indicated by a Creative Commons license in the record and/ or on the work itself. This Dissertation has been accepted for inclusion in WVU Graduate Theses, Dissertations, and Problem Reports collection by an authorized administrator of The Research Repository @ WVU.

For more information, please contact researchrepository@mail.wvu.edu. 
The effect of resident attitudes, social capital, and stakeholder engagement on rural tourism development in West Virginia.

\title{
Douglas Arbogast
}

\author{
Dissertation submitted \\ to the Davis College of Agriculture, Natural Resources and Design \\ at West Virginia University \\ in partial fulfillment of the requirements for the degree of \\ Doctor of Philosophy in \\ Forest Resource Science
}

\author{
Jinyang Deng, Ph.D., Chair \\ Kudzayi Maumbe, Ph. D., Co-Chair \\ Steven Selin, Ph.D. \\ David Smaldone, Ph.D. \\ L. Chris Plein, Ph.D. \\ Division of Forestry \& Natural Resources \\ Davis College of Agriculture, Natural Resources and Design \\ West Virginia University
}

Morgantown, West Virginia
2019

Keywords: rural tourism, sustainable tourism, destination management, SEM, social capital, transdisciplinary, mixed methods, DMO

Copyright 2019 Douglas Arbogast 


\section{ABSTRACT \\ The effect of resident attitudes, social capital, and stakeholder engagement on rural tourism development in West Virginia.}

\section{Douglas Arbogast}

While rural tourism has been a prominent topic of tourism research sine the 1970's, more research is needed to further identify key factors for success and methodologies successful in achieving both theoretical and practical outcomes that can advance field of study. This study attempted to apply a mixed methods approach, utilizing both quantitative and qualitative methods to explore factors for success by gathering data from a wide range of stakeholders attempting to triangulate results using a transdisciplinary approach. Multi-stakeholder engagement (key informants, local residents, and visitors) in the tourism development process is essential in identifying opportunities and challenges and appropriate methods to develop, manage, and market sustainable rural tourism as a component of a diversified rural economy.

The goal of this study is to identify, explore, and describe key variables for success in developing sustainable rural tourism. Both quantitative and qualitative methods were employed engaging a transdisciplinary team of faculty from West Virginia University and local stakeholders and organizations in Tucker County, West Virginia. Tucker County, WV was chosen as the study area due to its diversity of rural tourism attractions, active engagement by local stakeholders, opportunities and challenges it faces due to recent infrastructure improvements, and development of a Cultural District Authority (CDA) positioned to guide and support sustainable tourism development. Interviews were conducted with key informants; surveys were administered to local residents, visitors, and local businesses to better understand demographics, perceptions, preferences, and opinions; and design workshops were convened to identify factors for success in developing sustainable tourism in this rural destination. 
The first study utilized qualitative research methods which included 30 in-depth semistructured individual interviews with key informants representing a range of tourism-related organizations involved in destination marketing and management. The second study utilized quantitative research methods to analyze the effect of social capital on resident attitudes toward tourism and support for tourism development based on data collected from 637 local residents. Structural equation modeling and ANOVA were utilized as analysis methods. The third study utilized a transdisciplinary team of West Virginia University faculty employing a mixed methods approach that included key informant interviews; surveys of visitors and residents, an economic impact assessment of local business, and social design workshops to visualize development opportunities including site design and development of a cultural identity.

Results are subdivided into sections. In terms of key informants and destination management findings revealed a clear separation of marketing and management roles and responsibilities with separate organizations created with a primary mission for each role. Destination management challenges included maintaining authenticity and sense of place, staffing and quality personnel, pursuing target markets that minimize negative tourism impact and appreciate the uniqueness of the region, coordination, cooperation, and partnerships between businesspersons, local leadership, and rural tourism entrepreneurs, respect for local residents and positive economic impact for the community, and economic diversification. A destination management framework was developed based on the outcomes of the stakeholder analysis in order to define a structure for the roles and responsibilities for destination marketing and management activities. In addition, the study makes an important contribution to the existing body of literature on resident attitudes toward tourism and support for tourism by revealing the need to consider a common vision and participation in local organizations and informal social 
groups in addition to long-term planning, protection of community values, growth management, and the social and environmental impacts of tourism in order to secure resident support for tourism development. The transdisciplinary mixed methods study corroborated findings of the destination's opportunities and challenges through triangulation and allowed for engagement with more people and diverse stakeholders. Corroborated findings included the need for long term planning and managed growth; protecting community values; underutilized natural, cultural, and historic assets; the opportunity to develop nature-based, cultural, and historical attractions; and the need for a common vision and collective identity. This study makes a unique contribution to literature on mixed methods and transdisciplinary sustainable tourism development by incorporating social design into a transdisciplinary rural tourism planning project. The study concludes with recommendations for participatory planning to guide and support sustainable rural tourism development. Based on the results of the research and design activities the CDA adopted four tenets - Protect, Connect, Enhance, and Promote the Culture of Tucker County - and outlined its goals, objectives, and strategies in a performance agenda to guide the CDA's efforts as it works to achieve its vision of successfully implementing a community-led cultural tourism plan. 


\section{DEDICATION}

This dissertation is dedicated to all the people who in one way or another have influenced and helped me through this process. I am most grateful to my wife, Susan, daughter, Abby, and son, Will, without whose continual love, support and encouragement this would not have been possible. Also, to my parents who accepted my decision to take the long and windy road and trusted that it was going somewhere. To the land and people of Tucker County who showed me what a special place West Virginia is and welcomed me not as researcher and research subjects but as part of a family taking a journey together. I also dedicate this to my colleague, Paul Martin, whose passion for data and support for Extension research for more than 40 years is an

inspiration. To Bart who encouraged me to pursue a career, not a job, and to Nana who continually asked me when I was going to cut my hair and go back to college. 


\section{ACKNOWLEDGEMENT}

Funding for this study is from a grant awarded to the Tucker Community Foundation from the Claude Worthington Benedum Foundation. I would like to thank the Tucker County Cultural District Authority Board members - Brad Moore, Robert Burns, Diane Hinkle, Tim Turner, Jessica Waldo, Tim Turner, and L.E. Herrick for their help and cooperation developing the methodology, survey instruments, and in the data collection phase of the study.

Also, I would like to thank my major advisors, Dr. Jinyang Deng and Dr. Kudzayi Maumbe for their unwavering guidance, support, patience, and encouragement throughout my graduate program at WVU and through the course of this study. Similarly, I am thanking the other members of my committee: Dr. Selin, Dr. Plein, and Dr. Smaldone for their expertise, guidance, encouragement, and patience. In addition, I would like to thank my colleagues in the Family and Community Development Unit at West Virginia University Extension Service for encouraging and supporting me throughout all phases of this study. Special thanks to Paul Martin, WVU Extension Service’s Business Research Analyst, for his support with data entry

and analysis. Special thanks also to the Recreation, Parks and Tourism Resources Program and its faculty at West Virginia University for supporting me and sustainable rural tourism development in West Virginia. 


\section{TABLE OF CONTENTS}

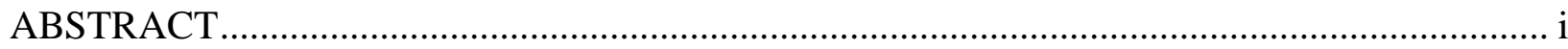

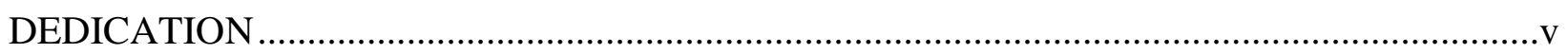

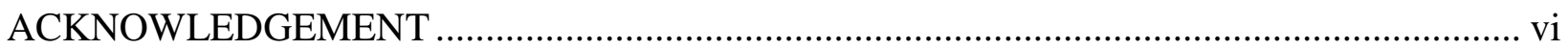

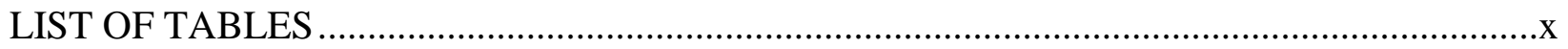

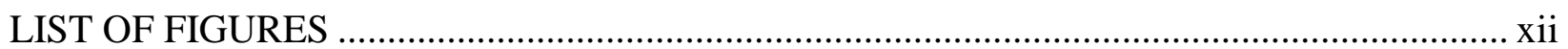

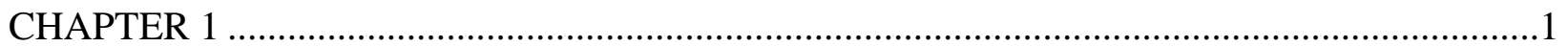

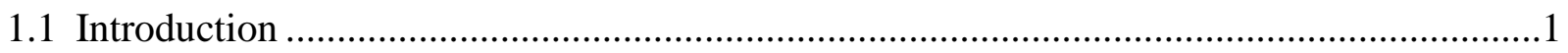

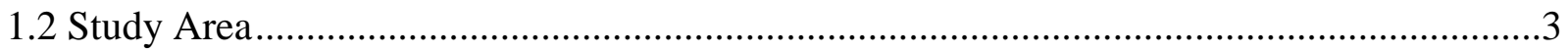

1.3 Structure and organization of the study ...........................................................................10

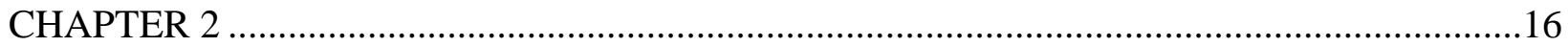

DMOs and Rural Tourism: A Stakeholder Analysis the Case of Tucker County, West Virginia .............................................................................................16

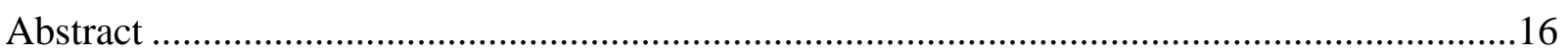

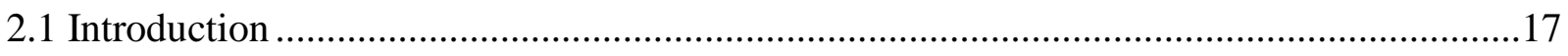

2.2 Theoretical Framework …………………………….....................................................19

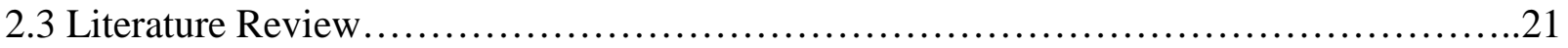

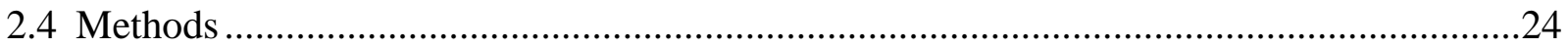

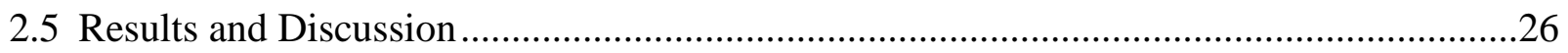

2.5.1 Rural Destination Management Challenges............................................................... 27

2.5.2 Destination Audit and Management Framework ………………………….............. 35

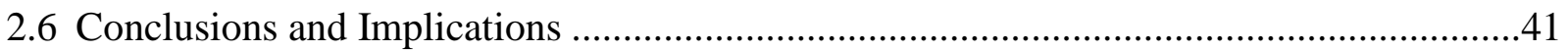

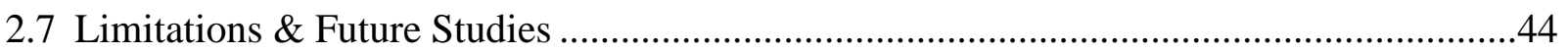

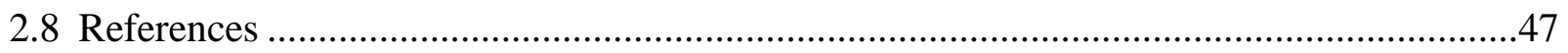

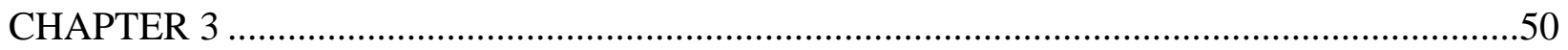

The Effect of Social Capital on Resident Attitudes toward Tourism and Support for Rural

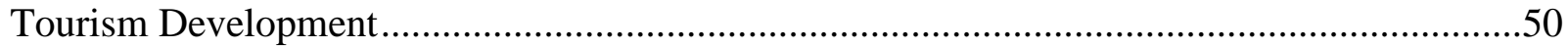

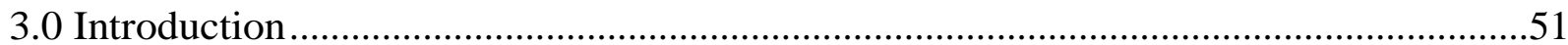

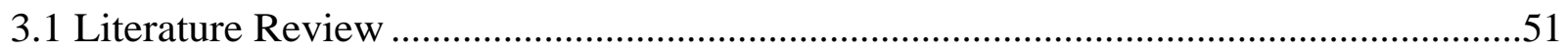

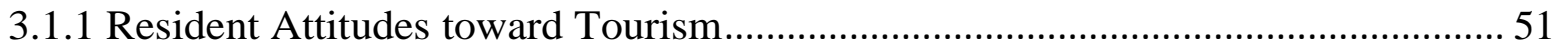

3.1.2 Resident Support for Tourism Development............................................................... 54

3.1.3 Social Capital and Tourism ...................................................................................... 55

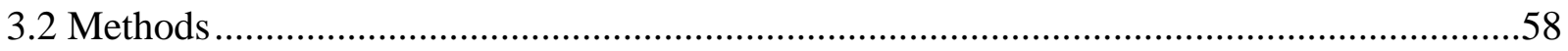




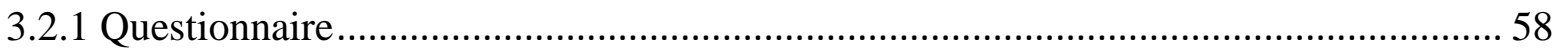

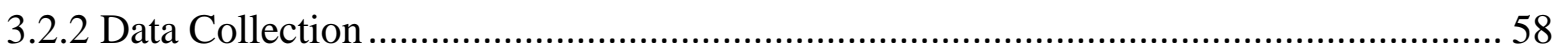

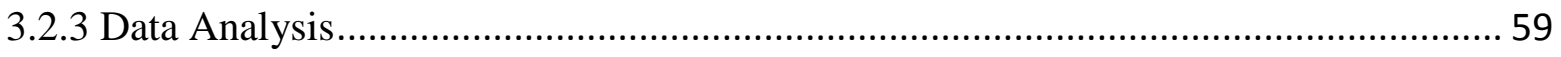

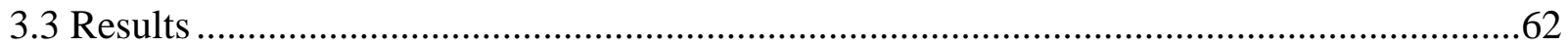

3.3.1 Socio-demographic characteristics of respondents...................................................... 62

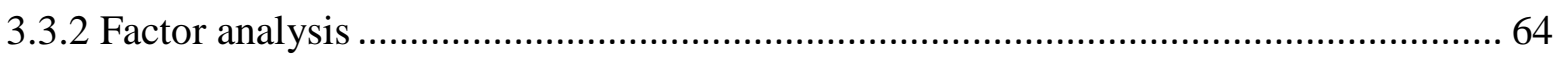

3.3.3 Measurement model ................................................................................................. 68

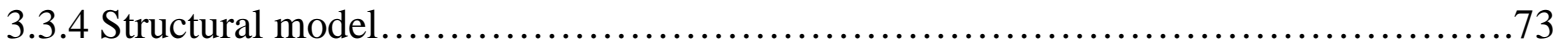

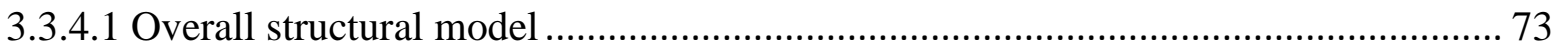

3.3.4.2 Multiple group comparison using SEM................................................................. 75

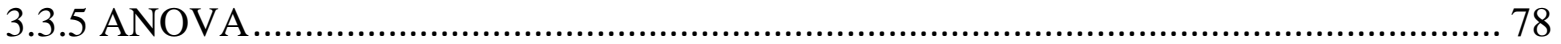

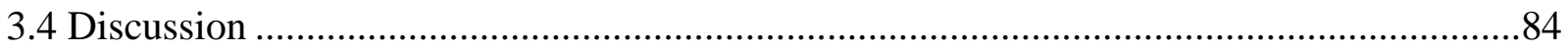

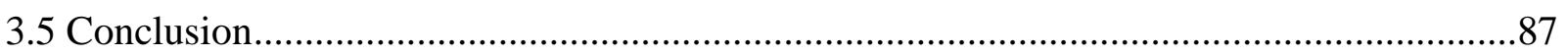

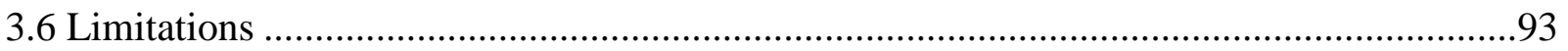

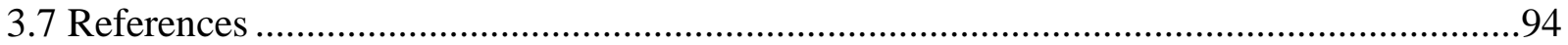

Appendix A: groups or associations in Tucker County that respondents volunteered with, worked for, or otherwise supported in Tucker County within the past 12 months...............106

Appendix B: What values do you feel are important in your community?................................108

Appendix C: What does tourism mean to you? ................................................................110

Appendix D: How can tourism benefit you personally? ............................................................111

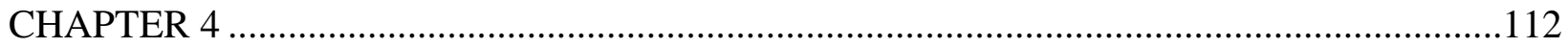

Social Design and Transdisciplinary Partnerships for Sustainable Rural Tourism Development..............................................................................................................112

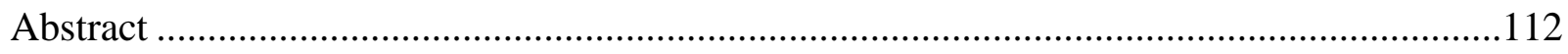

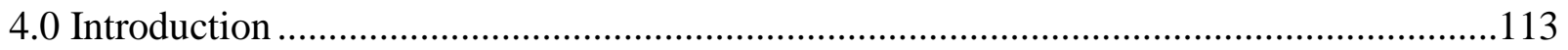

4.1 Literature Review ...............................................................................................114

4.1.1 Traditional Methods of Sustainable Tourism Planning ............................................ 114

4.1.2 Toward A New Paradigm - Social Design and Transdisciplinary Approaches ......... 115

4.1.3 Theoretical Framework ......................................................................................117

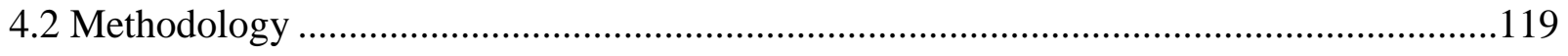

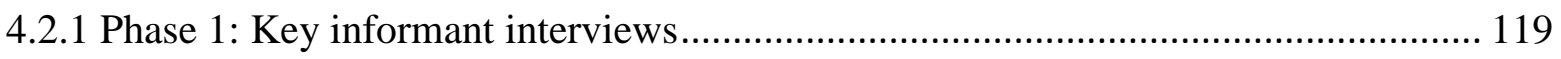

4.2.2 Phase 2: Resident attitudes toward tourism survey .................................................... 121

4.2.3 Phase 3: Visitor preferences survey ............................................................................ 122 
4.2.4 Phase 4: Economic impact analysis (current and development options).................. 122

4.2.5 Phase 5: Participatory Asset Identification and Mapping .................................... 123

4.2.6 Phase 6: Mapping of opportunities and priorities for tourism development and landscape design/visualization of sites targeted for development .................................. 125

4.2.7 Phase 7: Social design to create a cultural identity .............................................. 127

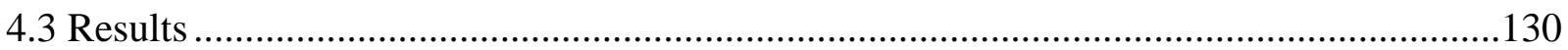

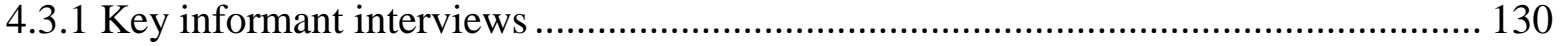

4.3.2 Resident attitudes toward tourism ................................................................... 132

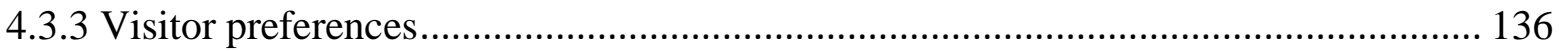

4.3.4 Community asset inventory and ARC GIS online mapping.................................. 141

4.3.5 Mapping of opportunities and priorities for tourism development and landscape design/visualization of sites targeted for development............................................... 142

4.3.6 Social design to create a cultural identity ....................................................... 145

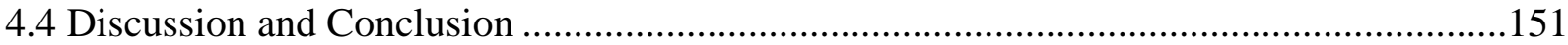

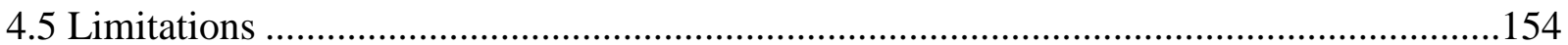

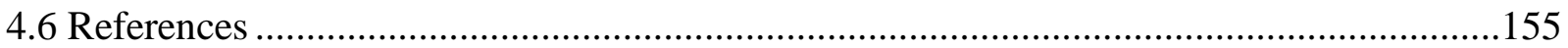

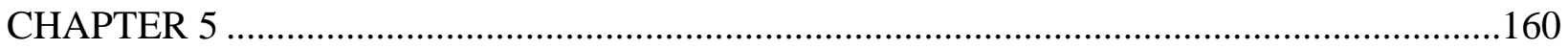

Linking the effect of resident attitudes, social capital, and stakeholder engagement on rural tourism development in West Virginia. ............................................................................160

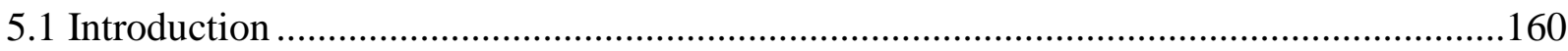

5.2 On key informants and destination management ...................................................161

5.3 On the effect of social capital and resident attitudes toward tourism on support for tourism

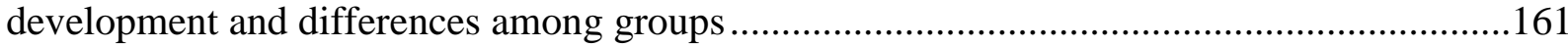

5.4 On mixed methods and transdisciplinary design.........................................................162

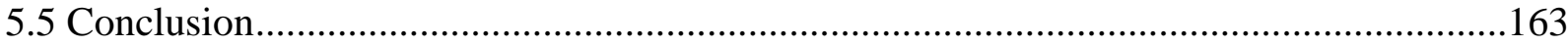

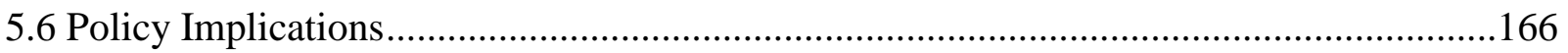

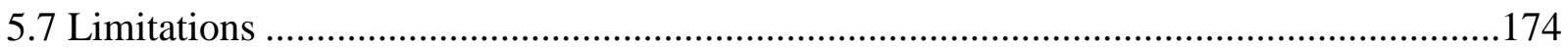

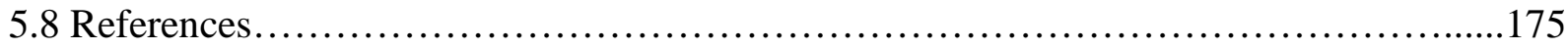

Appendix E Tucker County Stakeholder Interview Questions ............................................178

Appendix F: Survey Instrument ................................................................................... 


\section{LIST OF TABLES}

Table 1 Socio-demographic characteristics of Tucker County, WV resident population ............. 5

Table 2 Summary of the Activities of the DMO Categorized as Either EDM or IDD................ 20

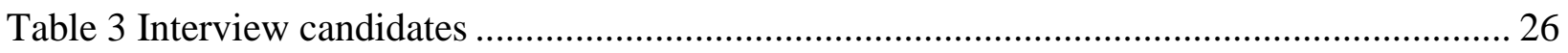

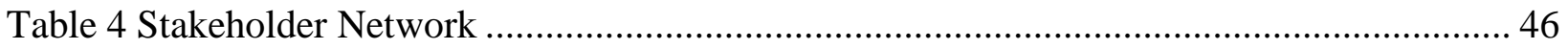

Table 5 Socio-demographic characteristics of the survey sample following listwise deletion $(\mathrm{n}=$

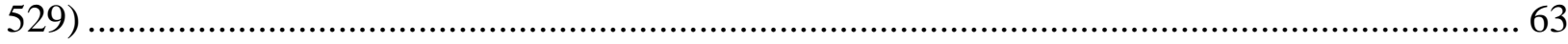

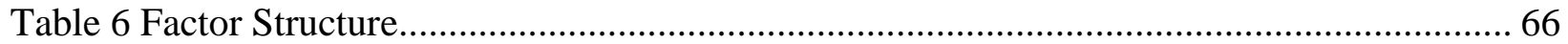

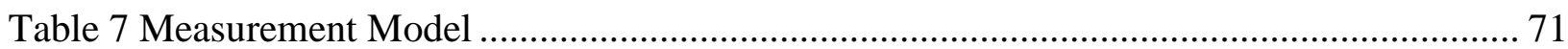

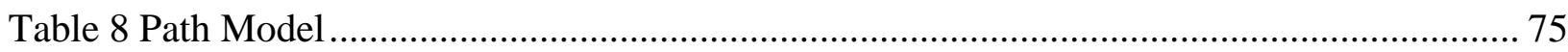

Table 9 Measurement invariance test between male and female.......................................... 76

Table 10 Direct effect, indirect effect, and total effect (male and female).............................. 76

Table 11 Measurement invariance test between high tourism and low tourism........................ 77

Table 12 Direct effect, indirect effect, and total effect (high tourism and low tourism)............. 77

Table 13 Measurement invariance test between short term residents and long term residents. ... 78

Table 14 Direct effect, indirect effect, and total effect (short term residents and long term

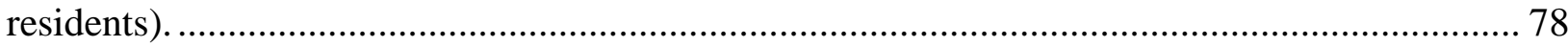

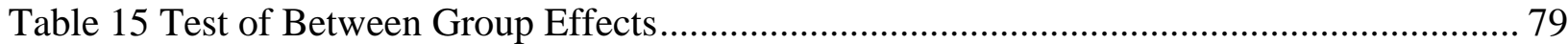

Table 16 Pairwise Comparisons of Social Capital, Attitudes toward Tourism, and Support for

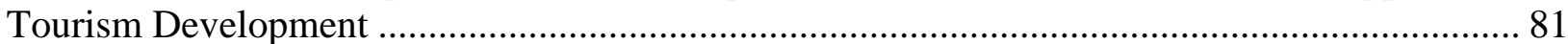

Table 17 Factor Means According to Role in Community................................................... 82

Table 18 Key Informant Interview Candidates............................................................. 121

Table 19 Socio-demographic characteristics of the resident survey sample $(n=637)$.............. 134

Table 20 Socio-demographics and trip characteristics of the visitor survey sample................. 137

Table 21 Economic contribution of the Tucker County tourism sector.................................. 140 


\section{LIST OF FIGURES}

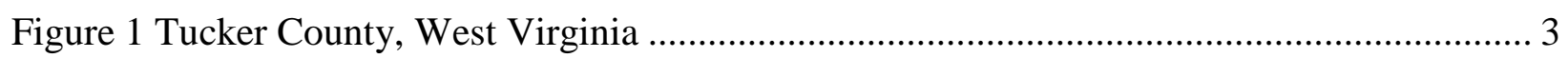

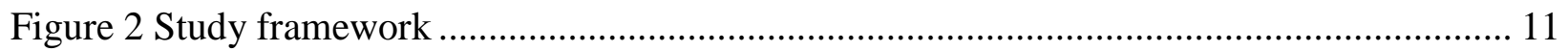

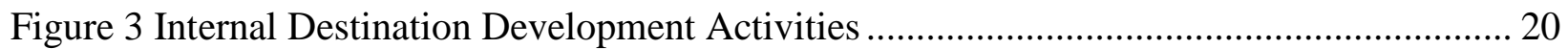

Figure 4 Descriptive Model of Destination Management in Terms of DMO Efforts in Internal Destination Development and External Destination Marketing ...................................................... 21

Figure 5 Tucker County Perceived Destination Management Framework .................................... 41

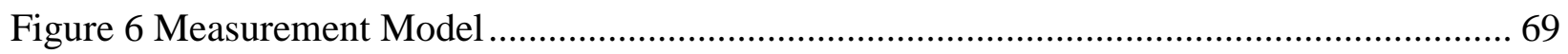

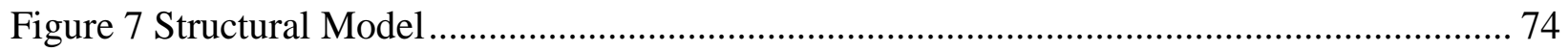

Figure 8 Project Phases ........................................................................................................ 119

Figure 9 Tourism Asset Inventory Data Collection Form ....................................................... 124

Figure 10 Tourism gaps and priorities input form ............................................................. 126

Figure 11 Mapping Results from Workshop ............................................................................ 127

Figure 12 Cultural identity design input workshop ................................................................ 129

Figure 13 Cultural identity design input form ....................................................................... 128

Figure 14 Tucker County, WV ARC GIS online tourism asset map.......................................... 142

Figure 15 Map of Road-biking Loops .................................................................................. 143

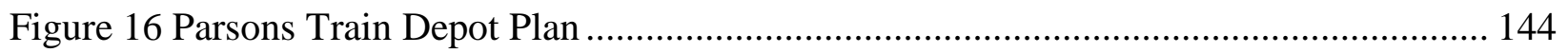

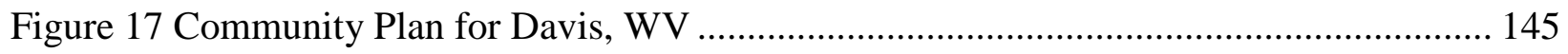

Figure 18 Participatory Cultural Identity Design Workshop...................................................... 146

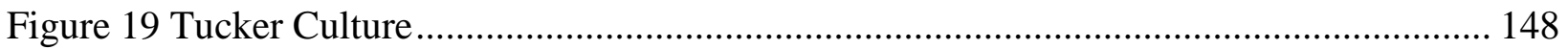

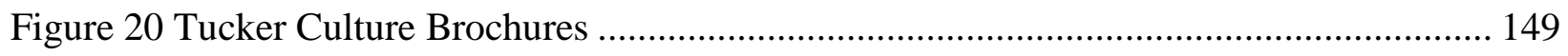

Figure 21 Tucker Culture Brand Standards Guide ………....................................................... 150

Figure 22 Tucker Culture Signage examples......................................................................... 151 


\section{CHAPTER 1}

\subsection{Introduction}

With the growing impact of tourism on West Virginia’s economy and society, opportunities exist to further develop and promote tourism resources in the Mountain State and attract visitors seeking a rural tourism experience. Many rural areas of the state can be considered at early stages of Butler’s (1980) Tourism Lifecycle model, likely having moved past the exploration stage to the involvement stage where the destination begins to provide facilities

primarily or even exclusively for visitors and contact between visitor and locals remains high and increases for locals involved in catering for visitors. Some advertising specifically to attract tourists begins, yet it is expected that a well-defined destination identity and brand is yet to be developed.

At these early stages of tourism development, the challenge of balancing the economic impact of tourism with the preservation of the rural landscape that West Virginia faces is not new. Numerous studies addressing the economic, social, and environmental impacts of tourism emerged in the 1970’s and '80’s. Jafari (1988) labelled the mid-1970s as the Cautionary platform, wherein unregulated tourism development may eventually result in "unacceptably high environmental, economic and sociocultural costs for the residents of destinations, who have the most to lose as a result of these costs” (Weaver, 2001, p. 6). It is during this time that ruralbased community studies began to assess not only the favorable benefits of tourism but also some of the environmental and socio-cultural impacts resulting from unplanned or poorly planned tourism development. Problems identified included the physical and environmental impact of feet, litter and vehicles, the economic impact of tourism's multi-nationals, and the social impact of mass visitation on cultures, heritage areas and objects (Lane, 1994). In addition 
to Butler’s (1980) tourism destination lifecycle model, well known early studies on why people travel and the impacts of tourism that emerged during this era include, Plog's (1974) psychographic profile of tourists, Cohen’s (1972) sociological profile of tourist typologies, and Doxey’s (1975) Irridex model of “irritations” which stem from the impact between residents and outsiders at any given tourist destination.

To maximize the positive impacts while minimizing the negative impacts of tourism development on a destination, it is necessary to understand attitudes held by local residents and other stakeholders toward tourism. Also, it is important to engage and empower local residents in tourism planning and development. Participative tourism planning has been promoted by scholars as a way to avoid the negative impacts of tourism. Participatory planning offsets some unintended impacts of tourism development such as anger, apathy or mistrust of tourists by locals (Gursoy, Jurowski \& Uysal, 2002). According to Reid, Mair \& George (2004) an important component of community-based tourism planning and development is active participation by all community members and stakeholders in all activities some of which include vision and goal setting; values clarification; asset inventorying and assessment; action planning; implementation; and monitoring, control and evaluation of development. Tourism literature is increasingly calling for more mixed-methods approaches and multiple perspectives, which several authors have claimed will result in a better understanding of the tourism phenomenon reviewed (Hollinshead \& Jamal, 2007; Lane, 2009). According to McGehee et al. (2013), in theory, mixed-method designs provide a "fuller field of vision" for researchers since they approach the research from multiple perspectives. 


\subsection{Study Area}

Tucker County is located in the Potomac Highlands region of West Virginia just west of the Allegheny Front (see Figure 1). In 1860 - just years after its founding - Tucker County's population was approximately 1,428. Access to large reserves of coal, limestone, shale, and timber shifted the economy away from agriculture. The county's population grew quickly in the late 19th and early 20th century - to over 18,600 residents in 1910 - as extractive industries and railroad access facilitated rapid industrial development and brought wealth and work to a previously remote community.

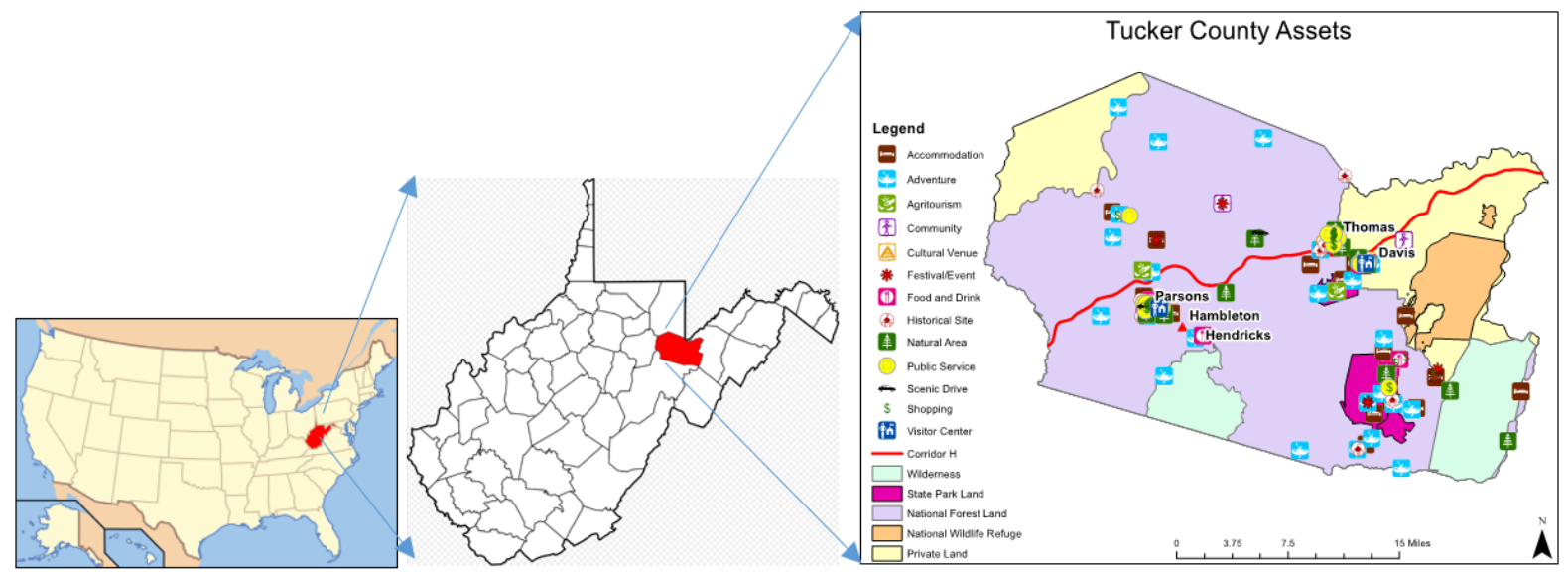

Figure 1 Tucker County, West Virginia

Tucker County was home to two railroads, two paper mills, three tanneries, fifteen sawmills, lime kilns, and almost a thousand coke ovens. After 1910 the population rapidly declined. Population spiked briefly in the 1980’s but has otherwise exhibited a small decline ever since. Recreation and tourism took on greater importance with commuting times from the Pittsburgh and D.C. Metro areas decreasing (Tucker County Commission, n.d.). The population density of Tucker County in the 2010 Census was just under 17.5 persons per square mile; only two counties in West Virginia reported a lower population density. According to the US Census Bureau’s 2012-2016 American Community Survey 5-Year Estimates the 
population of Tucker County was 6,922 persons, including 3,444 females and 3,478 males. Tucker County has an older population with $46.7 \%$ above the age 50 . Less than half of the local population (37.2\%) have attended college and $46.4 \%$ have annual family income of less than $\$ 40,000$. Residents are distributed among six communities. The two communities on top of mountain (Thomas and Davis) are home to 1,288 residents and the communities off the mountain in the valley are home to 2,018 residents. Table 1 provides additional insight into demographic characteristics of the Tucker County resident population. 
Table 1 Socio-demographic characteristics of Tucker County, WV resident population

\begin{tabular}{|c|c|c|}
\hline \multirow[b]{2}{*}{ Variable } & \multicolumn{2}{|c|}{ Proportion of the sample } \\
\hline & Frequency $(n)$ & Percentage (\%) \\
\hline \multicolumn{3}{|l|}{ Gender } \\
\hline Female & 3,444 & 49.8 \\
\hline Male & 3,478 & 50.2 \\
\hline \multicolumn{3}{|l|}{ Age } \\
\hline 1 to 24 & 1,730 & 25.0 \\
\hline 25 to 34 & 671 & 9.7 \\
\hline 35 to 44 & 782 & 11.3 \\
\hline 45 to 49 & 498 & 7.2 \\
\hline 50 to 59 & 1,163 & 16.8 \\
\hline 60 to 69 & 1,024 & 14.8 \\
\hline $70+$ & 1,045 & 15.1 \\
\hline \multicolumn{3}{|l|}{ Education } \\
\hline Less than high school & 879 & 12.7 \\
\hline High school & 3468 & 50.1 \\
\hline Some college & 1592 & 23.0 \\
\hline Undergraduate & 533 & 7.7 \\
\hline Graduate & 450 & 6.5 \\
\hline \multicolumn{3}{|l|}{ Income } \\
\hline Less than $\$ 20,000$ & 1571 & 22.7 \\
\hline$\$ 20,001-\$ 40,000$ & 1640 & 23.7 \\
\hline$\$ 40,001-\$ 60,000$ & 1426 & 20.6 \\
\hline$\$ 60,001-\$ 100,000$ & 1488 & 21.5 \\
\hline More than $\$ 100,000$ & 803 & 11.6 \\
\hline \multicolumn{3}{|l|}{ Years in Current Residence in 2016} \\
\hline 1 year or less & 78 & 1.1 \\
\hline 11 years or less & 1031 & 14.9 \\
\hline 8 to 16 years & 1274 & 18.4 \\
\hline 17 to 26 years & 1814 & 26.2 \\
\hline 27 to 36 years & 1301 & 18.8 \\
\hline 37 to 46 years & 824 & 11.9 \\
\hline 47 or more years & 678 & 9.8 \\
\hline \multicolumn{3}{|c|}{ Community of Residency (does not include second home owners) } \\
\hline Thomas & 612 & 8.8 \\
\hline Davis (includes Canaan Valley) & 676 & 9.8 \\
\hline St. George/Parsons & 1568 & 22.6 \\
\hline Hambleton/Hendricks & 450 & 6.5 \\
\hline \multicolumn{3}{|l|}{ Red Creek } \\
\hline Dry Fork & & \\
\hline
\end{tabular}


According to Data USA (2018), the economy of Tucker County, WV employs 2,993 people. The economy of Tucker County, WV is specialized in Mining, Quarrying, Oil, Gas Extraction; Utilities; and Arts, Entertainment, Recreation, which employ respectively 12.09; 3.01; and 2.87 times more people than what would be expected in a location of this size. The largest industries in Tucker County, WV are Healthcare \& Social Assistance (450), Public Administration (332), and Educational Services (309), and the highest paying industries are Mining, Quarrying, Oil, Gas Extraction $(\$ 59,231)$, Finance \& Insurance $(\$ 43,292)$, and Educational Services $(\$ 35,500)$. According the 2010 US Census, average per capita income in Tucker County was $\$ 37,591$, well below the national average of $\$ 52,251$. In Tucker County, the service sector accounted for $81.5 \%$ of employment in 2013, retail trade accounted for $7.7 \%$, real estate accounted for $5.5 \%$, health care accounted for $10.7 \%$, accommodation and food service accounted for $16.4 \%$, and state \& local government accounted for $17 \%$. However, the service sector accounts for just $63.3 \%$ of all earnings. In Tucker County, 34.8 percent of these households make less than $\$ 25,000$ per year. This statistic is above the state average for West Virginia at 31.9 percent and well above the national average of 23.4 percent.

Tucker County possesses world-class nature-based and adventure tourism assets including three ski resorts, two state parks (Canaan Valley and Blackwater Falls), the Heart of the Highlands trail system, hiking and biking trails, many rivers suitable for paddling, the Canaan Valley Wildlife Reserve, and the Monongahela National Forest. In sum, public and nontaxable properties total 53.47\% of the county's 269,869 total acres (Tucker County Comprehensive Plan, 2014). The Monongahela National Forest, 102,000 acres, 37\% of total acreage in the county) includes the Dolly Sods Wilderness Area which contains bog and heath eco-types, more typical of southern Canada. The Forest is known for its rugged landscape with 
spectacular views, blueberry thickets, highland bogs and "sods," and open areas with exposed rocks. Canaan Valley National Wildlife Refuge is one of 72 refuges in the Northeast and one of 562 refuges in the nation. The valley's high elevation and location combine to create a cool, moist climate more typical in Maine and Canada. Understanding the need to invest in infrastructure to continue to attract visitors, in 2013, the Canaan Valley State Park conducted a \$34 million renovation including 160 new guest rooms, a new tubing park, a new beginners ski area with surface lift, a wobble clay shooting range, ski lift renovations and major snow making system renovations. The communities of Thomas and Davis are being revitalized with small business development in their downtown districts and storefronts catering to the service needs of tourists (Tucker County Comprehensive Plan, 2014).

Tucker County is home to an arts community that has grown substantially over the past decade as evidenced by the numbers of resident artists, craftspeople, and musicians who pursue their art as livelihood. These craftspeople feed the galleries and performance venues that contribute to the County's economic viability. It is notable also that, for the most part, this growth has been self-motivated and independently developed, and that artists of all types are both long-time residents and people who have chosen more recently to settle here. These artists live throughout the County and their work can be seen and heard locally in multiple performance venues, six different galleries, and various other retail outlets. The strong presence of the arts in Tucker County, in addition to benefitting the local population, increasingly takes its place alongside sports, recreation, and nature as a motivation for tourism in Tucker County.

According to Runyan (2018) it is notable that the size of the travel industry in relation to the total economy of a locale is quite significant in a number of smaller communities and rural areas of West Virginia, which tend to be more orientated to scenic and outdoor recreational 
opportunities, including the counties of Greenbrier, Tucker, and Pocahontas where the travel industry is a significant component of the total local economy as measured by the proportion of travel-generated employment and earnings. During 2017, travel spending in Tucker County, WV was \$46 million which directly supported 780 jobs with earnings of \$16.2 million. Local and state government revenues generated by travel spending in Tucker County, WV were \$3.7 million in 2017 excluding property taxes (Runyan, 2015). Tucker County is located within 200 miles of Washington, DC and Baltimore, MD which are major source markets for both day and overnight visitors to West Virginia. Corridor H (officially designated as U.S. Route 48) is part of the Appalachian Development Highway System. US 48 is an east-west highway that runs 148 miles from northern Virginia to central West Virginia and is currently being developed into a four-lane highway. The transportation upgrades will improve the general accessibility of the county and make the region more accessible to out-of-state tourists from the east coast. The road is scheduled to be completed to Davis, WV in 2015 providing a four-lane access road for the first time in the history of the county. The West Virginia Department of Transportation predicts that average daily highway traffic will increase between two and three times the current level after completion of the highway (West Virginia Division of Highways, n.d.).

With the realization of increasing traveler interest for cultural experiences and the economic impact of cultural tourism development in other destinations, The Tucker County, West Virginia Cultural District Act was signed into law on April 29, 2013 in order to establish the Tucker County Cultural District Authority (CDA) which is authorized to promote the cultural, artistic, historical, educational and recreational opportunities available in Tucker County and thereby increase tourism and economic opportunities in the area (West Virginia Legislature, 2013). 
The Legislature finds and declares that:

1. The many and varied outdoor recreational activities in Tucker County, West Virginia, have long been an important element in a mature tourism industry for this state.

2. The two great state parks at Blackwater Falls and Canaan Valley, the Canaan Valley National Wildlife Refuge, the Blackwater Canyon, the Monongahela National Forest making up fifty percent of land in Tucker County, and the towns of Parsons, Thomas, Davis, Hambleton and Hendricks, are sources of pride to all West Virginians and mainstays of the important tourism industry in this state.

3. Tucker County, West Virginia, is the home to a growing number of artists, artisans and patrons of the performing arts. The burgeoning cultural tourism opportunities offered by the performing arts complement and enhance the outdoor recreational activities already existing in the area.

4. There is strong community-based support in Tucker County to encourage, develop and enhance the various aspects of the cultural tourism component of the regional economy. Opportunities exist to create, expand and compliment areas of cultural, historical, archeological and industrial heritage and educational interest in Tucker County.

5. The creation of additional employment and investment opportunities for the present and future residents of Tucker County is a desirable goal.

The Tucker County CDA is authorized to plan and execute an ongoing and continuous program for the development and enhancement of artistic, cultural, historical and recreational attractions that will promote culture, education and tourism in Tucker County, however, the CDA recognizes that additional information acquired through a participatory process is required 
in order to make informed decisions in the development of a program that will guide its activities and achieve its goals.

\subsection{Structure and organization of the study}

To fill a research void in West Virginia and help destinations at these early stages of tourism development better understand the potential economic, environmental, and social impacts of tourism development in order to empower destination leadership to plan for sustainable rural tourism development to grow and diversify their economies, this study aims to implement a mixed-method approach to transdisciplinary participatory tourism planning research to analyze resident attitudes toward tourism development, resident support for tourism development, the effect of social capital on resident attitudes toward tourism development, and the role of destination leadership in the development, management, and marketing of tourism.

The objectives of the study, therefore, are to examine the relationship among various rural tourism development factors in Tucker County, WV with emphasis on resident attitudes toward tourism, social capital, and stakeholder engagement in this rural tourist destination. Specifically, the study aims to:

1. Assess whether there are similarities among key tourism-related stakeholders (government, non-profit organizations, and businesses) roles in tourism development in Tucker County, the level of collaboration and networking among stakeholder organizations, and the role of a destination management organization in coordinating a strategy for sustainable rural tourism development.

2. Assess how social capital and resident attitudes toward tourism development will impact support for tourism development and how such impact might vary by socio-demographic variables including gender, length of residency, and level of tourism development. 
3. Triangulate outcomes from a transdisciplinary, mixed methods (quantitative survey of residents and visitors and qualitative network analysis among leaders) to develop a sustainable tourism strategy and policy for Tucker County.

Figure 2 illustrates the components and elements of the study including the relationship among them. In summary, the figure shows that the mixed methods data gathered from the respondents (i.e. visitors and residents of Tucker County, WV) included: 1) qualitative data from key informants; 2) a quantitative assessment of the effect of social capital on resident attitudes toward tourism and support for tourism development; and 3) transdisciplinary/mixed methods participatory planning. The data solicited from the respondents are then analyzed and discussed in terms of their influence and implications on the development and management of tourism in this rural destination. A description of the concentration of each chapter of this dissertation is given in the succeeding paragraphs.

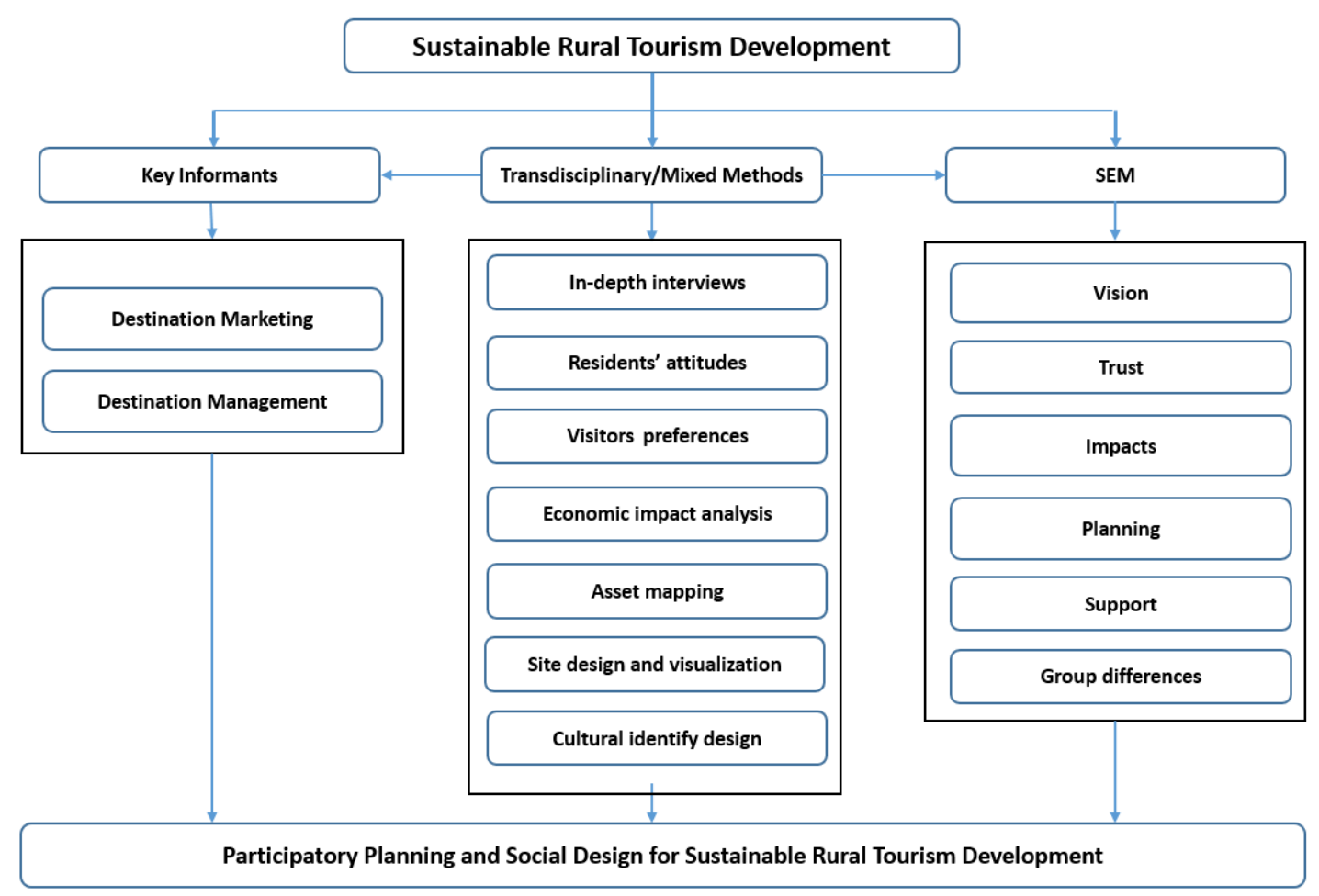

Figure 2 Study framework 
Each chapter in the manuscript focuses on each of the component in the data collected from the respondents. Each component is unique in its own and therefore analyzed using an appropriate statistical technique. Consequently, the results are explained in the context of the overarching theme of this study - sustainable rural tourism development.

Chapter 2 is a qualitative assessment of destination management challenges in Tucker County, West Virginia examining the relative importance of destination management from the perspective of key informants with a specific focus on the roles and activities of the destinations DMOs in addressing these challenges. Interviews with key informants were recorded, transcribed, and coded to identify themes including maintaining authenticity and sense of place; economic diversification; seasonality, low wage jobs, and lack of employees; connecting resorts to small businesses and communities; and establishing a common vision, identity, and coordination of activities. This paper uses the model of destination management proposed by Presenza, Sheehan, and Ritchie (2005) as the theoretical framework concluding with a perceived destination management framework for the destination.

Chapter 3 is a quantitative assessment of the effect of social capital on resident attitudes toward tourism and support for tourism development. This study focused on a quantitative research design which included a mailed survey to the entire population of residents of Tucker County, West Virginia with a valid mailing address. Data analysis included descriptive analysis, factor analysis, confirmatory factor analysis, structural equation modeling, multi-group analysis, and ANOVA. Results revealed that the potential environmental and social impacts of tourism and long-term planning have a direct positive effect on support for additional tourism development. The study also identified that a common vision and participation in local organizations and informal social groups has a significant direct effect on long term planning and 
protection of community values and an indirect effect on support for tourism development. In addition, significant differences were identified according to group, stake, and power in the community. Findings from this part of the study can help direct the management of resident attitudes and identify specific stakeholders to engage in the planning process in order to secure support for tourism from a broad sector of the community.

Chapter 4 describes the transdisciplinary, mixed methods, participatory planning, and social design activities developed and implemented by the West Virginia University Rural Tourism Design Team and associated outcomes. Quantitative and qualitative research in initial stages of the study (key informant interviews, resident attitudes toward tourism survey, visitor preferences survey, economic impact analysis) informed social design activities at latter stages (asset mapping, landscape design/visualization of opportunities and sites targeted for development, and cultural identity design) helping the destination take sequential steps toward achieving their goals and objectives. Findings from this study are discussed in the context of both its theoretical implications to mixed methods and transdisciplinary research and sustainable rural tourism planning and its practical application in the participatory planning process and associated outcomes.

Lastly, chapter 5 focuses on the discussion of the implications that the results of the study present as applied to specific aspects of sustainable rural tourism development: destination management, mixed methods/transdisciplinary approaches, and the effect of social capital on resident attitudes and support for tourism development. This section is aimed at giving credence to the importance of linking multiple methods together and support the notion that triangulation of data and a mixed methods approach can achieve more robust theoretical and practical implications for participatory planning for sustainable rural tourism development. In addition, 
policy recommendations are provided based on examples of resource deployment in

Pennsylvania, Minnesota, and Oregon to support sustainable rural tourism development.

\subsection{References}

Butler, R. W. (1980). The concept of a tourist area cycle of evolution: Implications for management of resources. Canadian Geographer, 24, 5-12.

Cohen, E. (1972). Toward a sociology of international tourism. Social research, 164-182.

Data USA (2018). Data USA: Tucker County, WV Economy. Retrieved from https://datausa.io/profile/geo/tucker-county-wv/\#economy

Doxey, G.V. (1975). A causation theory of visitor-resident irritants: Methodology and research inferences. Travel and Tourism Research Association Sixth Annual Conference Proceedings (pp. 195-198). San Diego, CA: Travel and Tourism Research Association.

Gartner, W. (2004). Rural tourism development in the USA. International Journal of Tourism Research, 6(3), 151-164.

Gursoy, D., Jurowski, C., \& Uysal, M. (2002). Resident attitudes: A structural modeling approach. Annals of tourism research, 29(1), 79-105.

Hollinshead, K., \& Jamal, T.B. (2007). Tourism and "the Third Ear": Further prospects for qualitative inquiry. Tourism Analysis, 12(1-2), 85-129.

Jafari J. (1988). Retrospective and prospective views on tourism as a field of study. Paper presented at the 1988 Meeting of the Academy of Leisure Sciences, Indianapolis, Indiana.

Lane, B. (1994). What is Rural Tourism? Journal of Sustainable Tourism, 2(1-2). 7-21.

Lane, B. (2009). Thirty years of sustainable tourism: Drivers, progress, problems and the future. In S. Gossling, M.C. Hall, \& D.B. Weaver (Eds.), Sustainable tourism futures: Perspectives on systems, restructuring, and innovations (pp. 19-32). New York and London: Routledge.

McGehee, N. G., Boley, B. B., Hallo, J. C., McGee, J. A., Norman, W., Oh, C. O., \& Goetcheus, C. (2013). Doing sustainability: an application of an inter-disciplinary and mixed-method approach to a regional sustainable tourism project. Journal of Sustainable Tourism, 21(3), 355-375.

Organization for Economic Cooperation and Development (1994). Tourism strategies and rural development. Retrieved from http://www.oecd.org/cfe/tourism/2755218.pdf

Plog, S. C. (1974). Why destination areas rise and fall in popularity. Cornell hotel and restaurant administration quarterly, 14(4), 55-58. 
Plog, S. (2001). Why destination areas rise and fall in popularity. The Cornell Hotel and Restaurant Administration Quarterly 42(3), 13-24.

Reid, D. G., Mair, H., \& George, W. (2004). Community tourism planning: A self-assessment instrument. Annals of Tourism Research, 31(3), 623-639.

Runyan, D. (2015). West Virginia Travel Impacts 2000-2017p. Retrieved from https://wvtourism.com/wp-content/uploads/2018/12/WVImp17p.pdf

Rosenow J, Pulsipher G. 1979. Tourism: the Good, the Bad, the Ugly. Century Three Press: Nebraska.

Tucker County Comprehensive Plan. (2014). Retrieved from http://tuckercountycommission.com/wp-content/uploads/2016/05/tucker-countycomprehensive-plan-plus-apendices-approved-revision-i-2014-08-27.pdf

Tucker County Commission. (n.d.). Tucker County History. Retrieved from http://tuckercountycommission.com/our-county/

U.S. Census Bureau: State and County QuickFacts. (2014). Data derived from Population Estimates, American Community Survey, Census of Population and Housing, State and County Housing Unit Estimates, County Business Patterns, Nonemployer Statistics, Economic Census, Survey of Business Owners, Building Permits. Retrieved from http://quickfacts.census.gov/qfd/states/54000.html

US Census Bureau. (2018). 2012-2016 American Community Survey 5-Year Estimates.

Weaver, D. (2001). Weaver, D. (2001). Sustainable tourism: Theory and practice. London \& New York: Routledge.

West Virginia Division of Highways. (n.d.). Corridor H. Retrieved from http://www.wvcorridorh.com/

West Virginia Legislature. (2013). Senate Bill No. 561 Tucker County Cultural District Authority. Retrieved from http://www.wvlegislature.gov/bill_status/bills_text.cfm?billdoc=sb561\%20intr.htm\&yr=201 $\underline{3 \& \text { sesstype }=\mathrm{RS} \& \mathrm{i}=561}$ 


\title{
CHAPTER 2
}

\section{DMOs and Rural Tourism: A Stakeholder Analysis the Case of Tucker County, West Virginia}

\begin{abstract}
Rural destination management organizations (DMOs) are faced with considerable challenges as they attempt to promote economic prosperity through tourism. This study sought to identify rural destination management challenges in Tucker County, West Virginia; identify the roles and activities of the destinations DMOs in addressing these challenges; and, develop a perceived destination management framework. Qualitative research methods were utilized which included 30 in-depth semi-structured individual interviews with key informants representing a range of tourism-related organizations involved in destination marketing and management. Stakeholders were selected in an attempt to cover a diversity of perspectives throughout the county. DMO challenges include maintaining authenticity and sense of place; economic diversification; seasonality, low wage jobs, and lack of employees; connecting resorts to small businesses and communities; and, establishing a common vision, identity, and coordination of activities. While the majority of tourism literature calls for DMOs to play a dual marketing and management role, this paper makes an important contribution by identifying the need for a Convention and Visitors Bureau and a separate organization with a specific mission to sustainably develop and manage tourism and coordinate activities of the stakeholder network.
\end{abstract} Keywords: rural tourism; destination management; DMO 


\subsection{Introduction}

Rural destination management organizations (DMOs) are faced with considerable challenges as they attempt to promote economic prosperity through tourism. These challenges often include managing growth while maintaining a sense of place, managing multiple objectives, limited funding for marketing and development, and limited capacity. According to Lane and Kastenholz (2015) rural tourism has failed to develop a destination management culture that can cope with these challenges and the decentralized, multi-player, multi-stakeholder nature of the rural tourism business and its essential links to the conservation and economic management of rural areas. This study sought to identify the challenges rural DMOs face as well as the appropriate role(s) of a rural DMO.

Funding for DMO activities in many destinations comes from accommodations taxes, which, according to Gartner (2004) has been the most significant policy to affect rural tourism development in the USA to date providing destinations with enough revenue-based funding to create Convention and Visitors Bureaus (CVBs). These CVBs are often the primary and sometimes sole DMO in many destinations. Since the primary funding source for CVBs comes from the "bed" tax, most small town CVBs often view their role as helping those businesses that collect the tax, e.g. putting 'heads on beds', and not responsible for issues regarding tourism development (Gartner, 2004).

Gartrell (1994) argued that the DMO is a marketing organization with the primary purpose to drive business to the destination, however, Ritchie and Crouch (2003) advocate the transition of the "M" in DMO to refer to "management” rather than "marketing” because the role of DMOs has strengthened and spread as destinations have attempted to play a more proactive role in fostering and managing the benefits of tourism development. Many current authors (Dore 
\& Crouch, 2003) recognize that marketing remains the principal purview of DMOs, however, there is a shift toward recognizing that the role of the DMO goes well beyond marketing to include other activities that are important to the success of tourism in a destination from a competitive and sustainable perspective. Pike and Page (2014) argue that very few DMOs have either the mandate or resources to effectively manage their destination and that this will depend upon the precise legislative or political framework established to guide each DMO.

Tucker County, West Virginia can be considered in the development stage of Butler's (1980) Tourism Lifecycle Model. Destinations are often most vulnerable in the development stage where effective destination marketing and management is most critical to sustain growth while addressing resident concerns from growth issues and establishing guidelines for resource stewardship and sustainability (Butler, 1980). The specific objectives of this study were to: (1) identify rural destination marketing and management challenges in Tucker County, WV, (2) identify the roles and activities of the destinations DMOs in addressing these challenges, and (3) develop a perceived destination management framework for addressing these challenges. 


\subsection{Theoretical Framework}

According to Presenza, Sheehan, and Ritchie (2005), the destination management organization's activities should include both an “external destination marketing” (EDM) function and an "internal destination development" (IDD) function and proposed a descriptive model, which captures both dimensions to reflect an overall destination management effort. The EDM function is meant to include all activities aimed at attracting visitors to the destination (see Table 1). These activities have an external orientation in that their aim is to influence the actions of persons outside the destination.

Internal Destination Development (IDD) activities are described as encompassing all other forms of activity (apart from marketing) undertaken by the DMO to develop and maintain tourism in the destination (see Table 2). The function of destination development is internal in that the activities are aimed at initiatives internal to the destination. Presenza et al. (2005), suggest that an important assessment of the DMO ability to foster IDD will be directly related to the number and quality of relationships with tourism destination stakeholders and to conduct network analyses to determine the strength of the DMO’s position (centrality) in the network vis-

à-vis the density of the network. Based on a sound core competency of stakeholder coordination, the DMO must establish a foundation for its IDD efforts by providing sound visitor management and information/research. From this foundation it is possible to develop the other dimensions of IDD (Quality of the Visitor Experience, Human Resources Development, Finance and Venture Capital, Resource Stewardship, and Crisis Management) that may be implemented by other stakeholders rather than the DMO directly (see Figure 3). 
Table 2 Summary of the Activities of the DMO Categorized as Either EDM or IDD

\begin{tabular}{|l|l|l|l|}
\hline External Destination Marketing Activities & \multicolumn{3}{l|}{ Internal Destination Development Activities } \\
\hline Web Marketing & e1 & Visitor Management & i1 \\
\hline Events, Conferences and Festivals & e2 & Information / Research & i2 \\
\hline Cooperative Programs & e3 & Coordinating Tourism Stakeholders & i3 \\
\hline Direct Mail & e4 & Crisis Management & i4 \\
\hline Direct Sales & e5 & Human Resources Development & i5 \\
\hline Sales Blitzes & e6 & Finance and Venture Capital & i6 \\
\hline Trade Shows & e7 & Resource Stewardship & i7 \\
\hline Advertising & e8 & Quality of the Visitor Experience & i8 \\
\hline Familiarization Tours & e9 & & \\
\hline Publications and Brochures & e10 & & \\
\hline
\end{tabular}

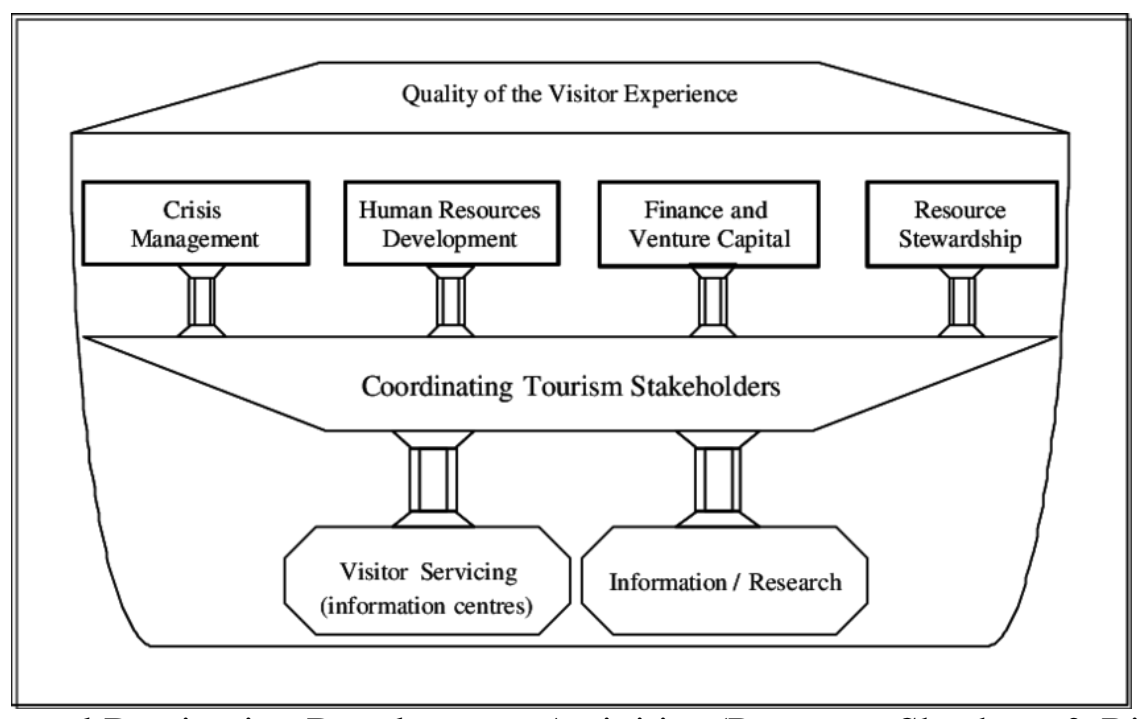

Figure 3 Internal Destination Development Activities (Presenza, Sheehan, \& Ritchie, 2005; adapted from Ritchie \& Crouch, 2003, p. 63); with permission from authors

A two-dimensional graph (see Figure 4) was produced with the vertical axis representing the DMO efforts in IDD and the horizontal axis denoting the DMO efforts in EDM. The position of the DMO in the model is the combined result of the interaction of its efforts on these two dimensions and therefore reflective of its effort in managing the destination. Greater efforts on either dimension will lead to an enlargement of the DMO's total efforts to comprehensively manage the destination. The assumption is that the DMO may be able to increase its resources to allow it to increase its efforts on one function. It is also possible that the DMO might not 
increase total effort but rather redistribute effort from one function to another to achieve more of a balanced approach to managing the destination (Presenza et al., 2005).

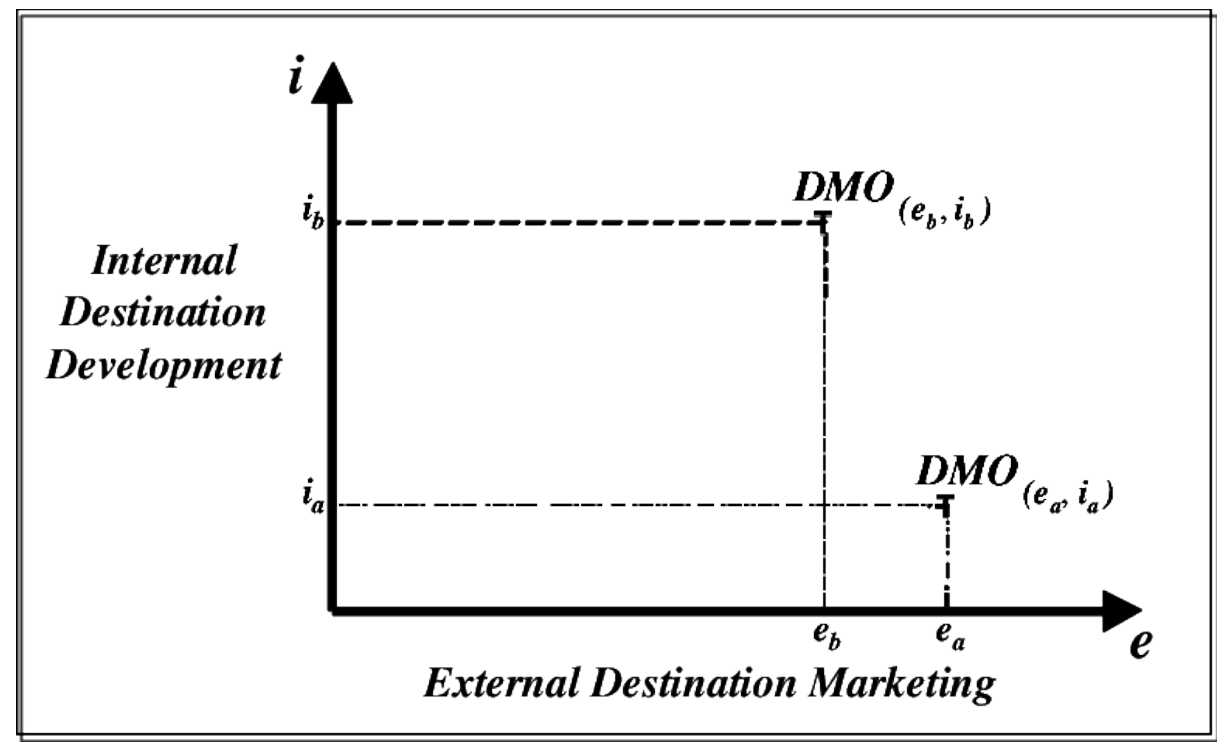

Figure 4 Descriptive Model of Destination Management in Terms of DMO Efforts in Internal Destination Development and External Destination Marketing (Presenza, Sheehan, \& Ritchie, 2005); with permission from authors.

Presenza et al. (2005), suggest that the model may be used by destination marketers or managers to perform a destination audit, whereby the DMO compares the activities outlined in the model to what they currently do and search for other organizations throughout the community that may partially or fully perform (or potentially perform) other activities since each DMO must assess its environment and select the most appropriate set of activities relative to its primary purpose and resources.

\subsection{Literature Review}

In order to achieve success in sustainable rural tourism, Wilson, Fesenmaier, Fesenmaier, and Van (2001) conducted focus groups with local tourism industries and community leaders in Illinois and identified that factors for success include a complete tourism package, good 
community leadership, support and participation of local government, sufficient funds for tourism development, strategic planning, coordination and cooperation between businesspersons and local leadership, coordination and cooperation between rural tourism entrepreneurs, information and technical assistance, good convention and visitors bureaus, and widespread community support for tourism. The University of Minnesota Extension Service (1991) identified five core values for sustainable community tourism development including maintaining authenticity and a sense of place, providing a quality experience, economic diversification, transforming obstacles to opportunities, and shared benefits and local control. A study by McGehee et al. (2013) to determine potential tourism centerpieces for the Blue Ridge Heritage Area elicited the following important values to guide the project: authenticity, sustainability, respect, positive economic impact, political sensitivities, and target markets that minimize negative tourism impact and appreciate the uniqueness of the region. Bornhorst, Ritchie, and Sheehan (2010) determined factors unique to DMO success as supplier relations, effective management, strategic planning, organizational focus and drive, proper funding, and quality personnel. According to the authors: "If the DMO does not provide leadership and direction for tourism development in the destination, who will?’’.

A study by Sharpley (2002) on the development of agrotourism in Cyprus identified challenges including lack of support, lack of training, lack of local facilities/amenities, low occupancy levels, ineffective marketing, and the dominance of mass tourism operators as major challenges concluding that long-term financial and technical support is essential if tourism is to play an effective rural development role. Additional studies in rural areas have determined that the quality of products and services must match tourists demands and expectations, thus, the total product package must be sufficient to attract and keep tourists, offering suitable opportunities for 
spending (Gannon, 1994); government subsidies may be required to maintain the social benefits of diversification into tourism (Fleischer \& Felenstein, 2000); and agricultural values and guestservice values are frequently incompatible (Fleischer \& Pizam, 1997).

The challenge rural areas face in balancing tourism growth with maintaining authenticity and sense of place has been noted by numerous authors. According to Bramwell (1994) the development of sustainable rural tourism has the potential to help secure the economic viability of rural communities and activities, which consequently can help maintain the special qualities of the countryside. George, Mair, and Reed (2009) argued that part of the appeal of rural tourism is the fact that more people are living in urban areas, and in these urban areas feel that they are losing their cultural identities and individuality. According to Plog (1974, p. 59) as destinations develop and cater to larger numbers of Psychocentrics they become increasingly commercialized over time thereby losing their authenticity and in turn "carrying with it the potential seeds of its own destruction.” The New Tourism described by Rosenow and Pulshiper (1979) seeks to develop within each community a sensitivity to its unique heritage and environment, the resources giving a locality its special sense of place.

According to Ritchie \& Crouch (2003), destination management involves establishing goals, making choices and balancing trade-offs with an overall vision for the destination in mind and tourism resources are likely to be used more effectively when the different modes of deployment share a common view regarding a destination's strategy for tourism development; however, challenges arise because a destination strives to achieve multiple goals, involves many different stakeholders, often lacks a focal organization that is able to see events from a bird's-eye view, and faces a difficult task in gathering the disparate information required to assess its performance. According to Volgger and Pechlaner (2014), exchange of information, use of 
synergies and coordination of action are supposed to positively affect destination development and are considered the building blocks for innovation and a versatile competitive base.

Unmanaged tourism, causing increased levels of competition between and within communities and relatives and subsequent social tensions, was viewed as a significant challenge for sustainable tourism in the Annapurna Conservation Area as was the dangers of unplanned tourism that put increased pressures on natural resource usage concluding that for sustainable tourism development to be successful, long-term partnerships between different stakeholders are essential (Holden, 2010). A study by Pasape et al. (2013) concluded that there is greater potential of sustaining ecotourism at any destination if all stakeholders are represented via networks and public private partnerships within and between sectors. Strategies identified to improve networks and public private partnerships included forming more ecotourism advocacy groups, involving local community members business and service providers; government agencies; researchers and academician in managing ecotourism, involving stakeholders at the local level, and establishing networks for the interests of stakeholders.

\subsection{Methods}

To effectively address the study objectives this study utilized a qualitative case study research design (Yin, 2014, p. 16). Qualitative research is designed to open "new paths of thought” (Talburt, 2004, p. 81) rather than verify a particular phenomenon. It can provide insights into how people think about complex issues in a tourist destination, such as tourism resources and impacts, futures for tourism, and preferred tourism scenarios (Yuksel, Bramwell, \& Yuksel, 1999). Interpretive research methods were utilized with the aim to collect rich and informed data. This included in-depth semi-structured individual interviews conducted within a two-month duration of fieldwork. Interviews were conducted with key informants representing a 
range of tourism-related organizations involved in destination marketing and management including the Convention and Visitors Bureau, Economic Development Authority, Cultural District Authority, local and county government, community foundation, private businesses, and non-profit organizations. According to the Organization for Economic Cooperation and Development, (1994), destination leadership or “key informants” are a critical stakeholder group in successfully developing rural destinations because the successful promotion of development and management planning requires more than usually informed, skilled and dedicated leadership.

Stakeholders were selected in an attempt to cover a diversity of perspectives throughout the county based on the researchers' knowledge of the local tourism industry and recommendations by board members of the Cultural District Authority. This technique yielded 30 interview candidates (see Table 3) which the authors believe to be a representative sampling frame. Interviews were recorded, and the data were transcribed as soon as possible afterward. Data collection and thematic analysis occurred concurrently, with early analysis informing later interview protocols. Data analysis included coding of the data to explore the themes generated in the field and to group different aspects of the data to compare emerging categories with those already unearthed in the literature, ensuring the selection of the most representative and inclusive categories. Data analysis was conducted using Nvivo 11 software. 
Table 3 Interview candidates

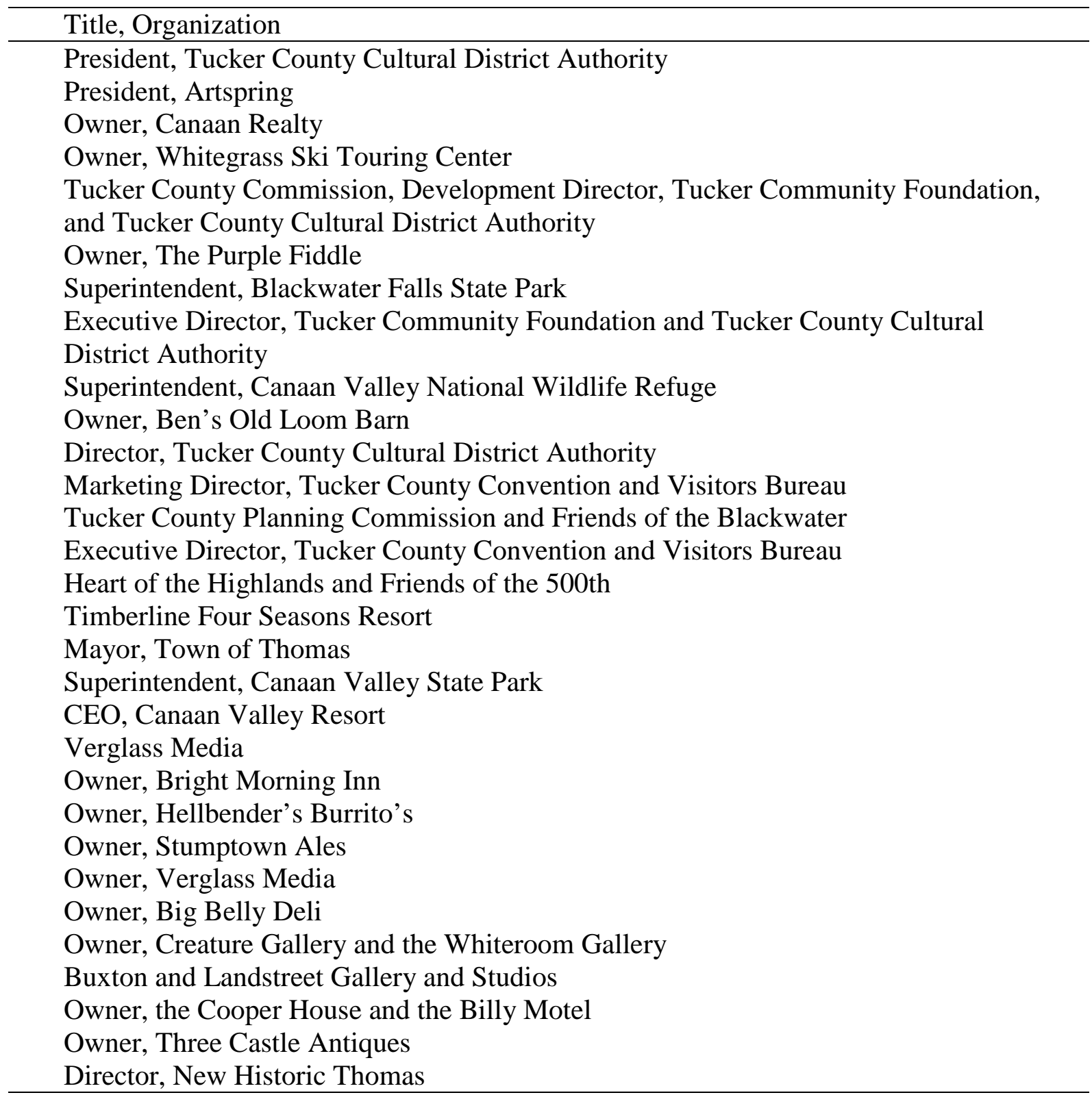

\subsection{Results and Discussion}

The key informant interviews revealed themes which included marketing and management challenges including addressing resident and visitor concerns for maintaining authenticity and sense of place while capitalizing on the improved accessibility of the destination; the need for economic diversification following the decline of extractive industries; 
coping with seasonality, low wage jobs, and lack of employees; connecting resorts to small businesses and communities; and establishing a common vision, identity, and coordination of activities. In addition to a better understanding of how stakeholders are addressing these significant challenges, the interviews identified numerous organizations involved in some aspect of destination marketing and management and allowed the researchers to conduct an audit of their roles and responsibilities and develop a destination management framework to guide the destination toward a more effective and coordinated management strategy. These specific challenges and the destination management framework are discussed in the following section.

\subsubsection{Rural Destination Management Challenges}

Maintaining authenticity and sense of place

Consistent with the findings of The University of Minnesota Extension Service (1991);

McGehee et al. (2013); Bramwell (1994); George, Mair, and Reed (2009); Plog (1974, 2001); Rosenow and Pulshiper (1979) maintaining authenticity was top of mind for many stakeholders with the completion of Corridor $\mathrm{H}$ cutting the driving time from Washington DC almost in half and with it the fear of the commercial development that often follows improved access. One stakeholder commented, "I mean you can get here in a lot less time. The road is beautiful, and I think as it progresses you're going to see numbers go up even more.” Others noted that visitors are aware of keeping things authentic and that the uniqueness is the primary draw for visitors because people appreciate and want to experience the small shops and breweries and restaurants that are non-chain. One stakeholder emphasized that, "the closest McDonald's is 20 minutes away, there's no chain hotels and that's what makes us unique.”

With accessibility comes hopes of more visitors and increased revenue but also fears of overdevelopment and commercialization. The recent completion of Corridor $\mathrm{H}$ has triggered many conversations and spurred many community groups to action to ensure that 
they maintain control of their destiny while harnessing the opportunity for economic development that improved access brings. With Washington, D.C. within a 3 hr. drive they are starting to see more day visitors which has the potential to increase revenue, yet there is concern about what the new highway is going to do for or to the area. With the development of second homes, the increased demand on the land, the increased use of the hotel rooms, lodging rooms, one stakeholder emphasized that, "it’s a very real conversation.”

Stakeholders mentioned the importance of maintaining the authenticity as a key component to attract visitors who then want to relocate and become residents for the destinations unique qualities that they can't find elsewhere, and which is key to making them want to become a permanent resident. One stakeholder commented that, "I think a lot of those people you know realize the importance of preserving that uniqueness of this area because that's what brought them here.”

Stakeholders expressed concern about unleashed tourism and impacts they had seen in other destinations where in their opinion too much tourism ruined it to the point that they did not want to return and economic gain drove development not community interests. In their opinion, "there's nothing wrong with it [tourism development] unless you keep it under control and it doesn't turn into Disneyland, I think a lot of destinations have. That is the only thing that would concern me is uncontrolled growth.” Another stakeholder commented, "we’ve seen other areas similar to us where the tourism has been uncontrolled, and it just expands wildly and develops things that are not necessarily pro community, it might be pro tourists but not necessarily pro community."

Another stakeholder commented that a key to maintaining authenticity is the need to attract the right type of visitor, i.e. the cultural tourist, "I do think that the type of tourists I 
personally want to encourage are the stewards of the outdoors, people who are concerned about what they leave behind, you know what sort of footprint they're making.” This is the early stage of development that Plog (2001) recommended as an ideal destination stage appealing to Allocentric/Venturer types. The ideal positioning on Plog's psychographic curve lies near the middle of the Near-Allocentric/Venturer segment of travelers where the destination usually has a reasonable level of development, but it hasn't gotten out of hand or lost its uniqueness. New wealth has improved the living conditions for local residents; however, planning and control is imperative at this stage because many unplanned destinations face a declining future because uncontrolled growth discourages venture-type travelers.

Zoning ordinances are one mechanism to control development. Canaan Valley established zoning regulations in the 1998 (Canaan Valley, 1998). It is the only place in Tucker County that has had zoning regulations which includes guidelines about billboards, roadside signs, lighting, how close you can build to your neighbor, etc. Some residents resist any control or oversight of development. Some see zoning as a very evil thing; but, there's been a group of people across time who have recognized the importance of having some kind of plan to guide and control that growth so that it will happen in a way that is compatible with the area in order to “enhance it, not change it.” Other stakeholders commented on the opportunity to develop regulations to manage growth in order to "protect our natural assets and to manage growth in a way that benefits nature as well as the populace here from an economic standpoint, and even more importantly from a quality of life standpoint.”

\section{Economic diversification}

As Tucker County’s economy transitions from one based solely on coal and timber extraction, local stakeholders expressed the need to focus on not only attracting tourists but also 
the opportunity to attract people to visit who may want to live and work in a rural community and help diversify the economy. Residents of urban areas come as tourists and often end up deciding to stay here because as one stakeholder noted, "that's where tourism is not just about what happens on Memorial Day weekend, it's about making people want to become part of the community.”

For many years, the economy in this county was based on coal and timber. Now, many young people have to move away for employment opportunities. One stakeholder noted that tourism brings in diversity and can help turn around the brain drain by bringing in people with new ideas and with technology it's easier for people to relocate because "it's a secondary effect of bringing people here who know how to get into a more modern business climate you know the coal mining is gone here and that's a hard, hard pill to swallow.”

Another stakeholder commented on the need to focus on the intrinsic qualities of the destination and the quality of life found in rural areas that can attract the right kind of people to become permanent residents. It is the connection with nature, clean air, clean water, healthy forests and a high quality of life that stakeholders felt will make people want to be there, and with that bring their skill sets and possibly jobs. One commented that the focus for economic development needs to be on smaller scale entrepreneurs who want to live there for the intrinsic qualities that the county already has.

Seasonality, low-wage jobs, lack of employees

Although the people, natural beauty, and rural setting has been attracting visitors and permanent residents and Tucker County, WV is fortunate to have both summer and winter activities, numerous stakeholders commented that one of the biggest challenges in running a tourist business is the seasonality since they can be just overwhelmed with people on certain 
weekends and then be very slow and that it’s hard sometimes to keep employees motivated managing a business when there are visitors and money coming in some months and then there are months where there are few visitors and little revenue. One business owner commented that "when tourists are not traveling then it's really hard to survive until the next time the tourists come; you got to be really good at planning ahead and saving for your future dry months.” Other business owners commented that the growth that is projected should include more businesses that can sustain themselves on a year-round basis that somehow there has to be a mixture of businesses coming in that can stay open thereby bringing in more people at times that can feed off into the existing businesses.

Finding employees willing to work in tourism businesses is also a challenge since a lot of the jobs are fairly low-paying and seasonal, which makes it very hard to get ahead and plan and support a family working in the tourism industry. Many have to work three different jobs at a time to get by. Others commented that the biggest downside to running a business is the lack of employees since it is a very rural area and very few people live there; so, finding people who want to work in tourism businesses who are seasonal and often low-wage is a big challenge. The resorts also commented on the challenge of finding employees to work not only the entry level positions but also the higher wage management positions.

Connecting resorts, small businesses, and communities

Small business owners discussed being actively engaged in sharing information and coordinating their activities so that they aren't competing with the visitor's time, but instead collectively trying to grow the customer base in Tucker County together and together creating a bigger attraction for Tucker County because as one local business owner noted, "we can’t do it by ourselves and so we've got to cooperate in order to build that customer base together, because 
after all, there is a limited amount of people that come to town on any given day and we want to share in those customers."

Though small business owners are cooperating to grow the customer base, some discussed the challenge of connecting their small businesses with visitors at the nearby state parks and resorts and encouraging visitors to leave the parks and visit lesser-known attractions in order to spread the economic impact of tourism throughout the county. The two resort state parks in the county serve as anchor attractions, attracting thousands of visitors a year, yet some in the community view the resorts as islands with walls that try to keep visitors within the confines of the resort in order to maximize visitor spending. Yet, state park leadership is working to be more collaborative and encouraging the other attractions in the community to benefit from them and vice versa through a collaborative relationship by reaching out and working with local business owners and trying to open doors to let the local community know how to cooperate and establish relationships. A state park superintendent discussed the opportunity he sees in partnering with other local attractions,

We do want to push our people out and go see these other places, if we were able to push them to let's say Thomas, they'd fall in love with that place. They'd fall in love with Davis. And they're just two cool towns with two different histories. Snowshoe is trying to artificially build what we already have here, which is a community. They have their village with shops and things. Well, we already have that except its natural and it's historic.

These statements are consistent with the findings of Ritchie \& Crouch (2003) and Volgger and Pechlaner (2014) that due to the many disparate elements that comprise the tourism product, as Tucker County, WV matures as a tourism destination it faces a critical need for these 
attractions to not work in silos and compete against one another but for greater coordination of activities and experiences, exchange of information, and use of synergies.

Vision, Unity, Collaboration, and an Identity

The key informant interviews identified multiple organizations with a primary responsibility for destination marketing and management activities in addition to a number of supporting organizations and businesses. It was apparent that the stakeholders in Tucker County want to work together and that the competitive businesses, local municipalities, and community organizations realize that they're stronger if they collaborate.

Although there are a lot of organizations actively trying to improve the destination, establishing a common vision and coordination of activities were key challenges discussed. While stakeholders agreed that the county is fortunate to have a lot of hard-working people with community organizations, non-profits, and volunteers actively engaged in promotion, community revitalization, art, trails, heritage, music, etc., one stakeholder noted that "it would be nice if an individual or an organization would take on that lead role as part of their business to coordinate an effort to pull us all together cohesively.” This need for coordination is critical and consistent with Presenza et al. (2005) determination that an important assessment of the DMO ability to foster IDD will be directly related to the number and quality of relationships with tourism destination stakeholders, and that without a sound core competency of stakeholder coordination, the DMO will not have a foundation for the other dimensions of IDD.

A common vision was also identified as missing and needed to guide the coordination. One stakeholder commented, “we’ve realized that there are many visions and many parallel visions of where Tucker County is going, so we are working on a more unified vision for where we're going.” This is consistent with the findings of Ritchie \& Crouch (2003) that tourism 
resources are likely to be used more effectively when the different modes of deployment share a common view regarding a destination’s strategy for tourism development.

In addition to coordination and a common vision, more unity and collaboration amongst the communities and organizations was identified. According to one stakeholder, "there's a lot of things going on but there's not necessarily a unity to the whole thing.” Key informants stressed the importance of bringing everyone to the table to have more dialogue about what is happening in various parts of the county so that "Davis knows what Thomas is doing, what Parsons is doing, what Hendricks is doing, so that there's some continuity and consistency and some agreement that this is what's best not just for your community, but for the entire county.” It was clear that the leadership recognized the importance of establishing this common vision, unity, and collaboration in order to sustainably manage the destination; and, that establishing a process to accomplish this was a considerable challenge that was evolving over time, but that the process was being initiated, and that they were actively encouraging everyone in the community to be part of that process as it develops.

Others commented on the need to establish an identity that represents these cultural assets. One stakeholder noted that Thomas’s identity as an arts town was purposefully done when some artists moved there. They decided that they wanted that to be their identity, they created that, and it's brought in more artists. The Davis Renaissance group is working to be a unified voice in order for others to recognize that they have a community that they can make something of, and is worth the state investing in. One stakeholder commented on the need to find the identity that can lead to investments. 
There's a small microcosm of everything that's happened in this country in this county and capturing that identity and then being able to present to the state to say we can be a little gem for you we just need the investment to smooth our edges.

\subsubsection{Destination Audit and Management Framework}

A key challenge with establishing this common vision, increased collaboration and unity, and managing a destination management process was identifying which organization would assume these activities as a core component of their mission. There are numerous organizations in the county with a role in tourism marketing and/or management. An audit of the role(s) of these organizations in destination marketing and managing as suggested by Presenza et al. (2005), whereby the DMO compares the activities outlined in their model to what they currently do and searches for other organizations throughout the community that may partially or fully perform (or potentially perform) other activities was conducted in an attempt to develop a perceived management framework.

The Tucker County Convention \& Visitors Bureau’s (CVB) mission is to support, sustain and assist in the growth of the tourism industry in the county. The main source of funding for the CVB is $50 \%$ of the hotel/motel occupancy tax collected throughout Tucker County. This $6 \%$ fee is collected from visitors staying 30 days or less in hotels, motels, vacations homes, condominiums and bed \& breakfasts. According to the CVB's Executive Director, “more than 80 percent of our budget is spent on advertising Tucker County as a tourism destination, encouraging people to come and spend a couple of days, and enjoy all that Tucker County has to offer.” In addition to staffing a visitor's center in downtown Davis, WV, advertising mediums include print media, earned media, social media, digital marketing, direct mail, radio, and consumer travel shows. The visitor's center provides services and information for guests to the 
area and is staffed by hospitality professionals (Waldo, 2015). This is consistent with the findings of Gartner (2004) that since the primary funding source for CVB's comes from the "bed” tax, most small town CVBs view their role as helping businesses that collect the tax, e.g. putting 'heads on beds', and not responsible for issues regarding tourism development.

Envisioning the potential impact the improved access might have on the county, and with the realization that an organization did not exist with the sole mission to protect the culture of the county, local residents proposed forming a Cultural District Authority. They realized that the Development Authority is instituted for industrial/commercial development and while they are involved in some tourism development they can’t do all of it; and, the CVB is designed for marketing of tourism and is limited in development work based on their bylaws and their funding source, so no single organization is in place to develop the assets that could then be marketed. The purpose of the Cultural District Authority being formed was that local residents realized the role they needed to fill in order to preserve the culture for future generations.

The Tucker County Cultural District Authority (CDA) was authorized by the West Virginia Legislature in 2013, to plan and execute an ongoing and continuous program for the development and enhancement of artistic, cultural, historical and recreational attractions that will promote culture, education and tourism in Tucker County (WVSB561, 2013). The CDA consists of seven board members who must be residents of Tucker County. One of the board members must be a county commissioner and the other six must demonstrate an interest in cultural tourism and be recommended by the County Commission and appointed by the Governor. Current board members include the President of the Convention and Visitors Bureau and the Executive Director of the Community Foundation. The CDA was able to leverage a small portion of the hotel-motel tax from the County Commission in order to provide mini-grants 
for tourism development projects. A CDA board member discussed the role of the CDA in comparison to the other organizations in the county:

We're moving slowly through the process to establish ourselves, we need to understand our role, we need to make sure that we are engaged in all of the groups in the county who make up the culture of Tucker county, it goes everything from outdoor recreation to the historical attractions to the arts and crafts to the food, the farms, the coal mining so you know trying to embrace all of that and trying to capture it so that any visitor coming into this county understands the wealth of culture here, that's a daunting task.

The Tucker County Economic Development Authority’s (TCEDA) mission is to encourage economic growth and opportunity in the area, to enhance and maintain economic development, and to preserve Tucker County's values and heritage (Our Mission, 2012). Its role is to promote economic prosperity but also to retain and celebrate the county's cultural heritage and in doing so attract companies to Tucker County. Although EDAs in rural areas are often more focused on traditional forms of economic development like manufacturing, the TCEDA's role in tourism is evolving as tourism increasingly plays an important role in the economy of Tucker County. They support tourist-based businesses by helping them develop strategic plans, as well as getting them access to capital, and helping them identify and even sometimes helping to interview some of their employees. They also try to make sure that there's a connection between local residents and tourist focused businesses because according to the TCEDA Executive Director, "that's how we make the soul of our community, is that the residents feel like they can also participate and be part of what these tourist businesses have to offer, and helping our tourist businesses be ambassadors for the rest of the community.” 
The Tucker County Commission administers programs and services for Tucker County, is led by 3 County Commissioners, and is home to 5 municipalities including Davis, Hambleton, Hendricks, Thomas, and Parsons (Tucker County Commission, n.d.). A County Commissioner described the role of the Commission in tourism as being a good ambassador for the county, being united and welcoming to tourists to this county because "it's important to our economy, but it's also just important to have people like to come and play here and maybe they'll eventually stay here.” The Tucker County Commission is actively involved in providing leadership, oversight, and funding for tourism marketing and management.

The Tucker Community Foundation (TCF) is a public charity that serves 8 counties in North Central West Virginia and Garrett County, MD. Since the organization was formed in 1989, it has granted more than $\$ 6$ million to support local initiatives, many of these initiatives supporting the growth of the tourism industry. Current projects include the Tucker Boulder Park, and Run For It, an annual 2k/5k that provides a large cash purse for non-profit community causes (About TCF, 2015). According to the TCF Development Director, "to witness the impact of local philanthropy and when you see how everyone through this whole region has gotten engaged in local philanthropy, to have that kind of grassroots support is quite amazing.” As a CDA partner, the Tucker Community Foundation is instrumental in obtaining grants and distributing funds for tourism projects.

While numerous organizations have been formed to focus on specific niche opportunities in order to support growth in targeted areas such as art and trails, this has spurred the need for coordination of activities across the county. Artspring is an organization as well as a festival founded in 2011, dedicated to supporting the arts community by providing services to them and making sure that the general public sees the benefit of that in the community, appreciates it and 
is proud of it. The role of the organization is to be concerned about the roles that the arts play in economic development and tourism because as described by the executive director, "we believe it's the arts that people will see as a reason to come here, and that will be a key piece of the economic development of the area.”

Blackwater Bike Association is committed to establishing an outdoor recreation-based community with a core of mountain bikers who have established a local chapter of the International Mountain Biking Association, which is establishing relationships with local landowners and business owners in trying to propel mountain biking so that it can grow. According to one board member, "we just like riding our bikes we just want people here to enjoy what we do -- that's really what it comes down to.” The chapter organizes the Canaan Mountain Bike festival in June each year.

Friends of the 500th is a volunteer group supporting the Canaan Valley National Wildlife Refuge. Canaan Valley National Wildlife Refuge uses the group to advocate for habitat management for outreach for supplemental income. The Friends' mission is to support the refuge, to ensure public use, public access to public lands, and within that it's protecting natural resources and protecting cultural resources and providing environmental education opportunities.

Heart of the Highlands mission is to connect the trails that exist on all the public lands in Tucker County, and be able to present the trail system as a whole instead of as multiple parts, and to get the public land managers to be able to work together and meet some of the other stakeholder needs that have been identified. According to the organization's project administrator, “everybody is receptive to the idea and we've been able to make some giant strides forward in working together and reaching ideas and plans that everybody can be receptive to and fully support.” 
In addition to niche tourism organizations, community revitalization groups have formed to focus on specific opportunities within communities and downtown revitalization where infrastructure built to support extractive industries is being repurposed to provide services to visitors. The New Historic Thomas organization is a nonprofit community organization that was founded in the 90's as a group of volunteers who really care about the community and want to see the downtown revitalized. Their goal is to encourage visitors and residents to stay in Thomas all day and visit galleries and eateries and then go hop on the trails. According to the Mayor of Thomas, “we're very lucky to have a nice group of young people who really like where they are and are making a contribution towards where they are.”

The Davis Renaissance committee's primary goal is to help beautify and make the town of Davis a little more attractive, by adding a little more curb appeal and vibrance to create a collective, uniform look throughout town to make it look more welcoming. According to one board member, "Davis Renaissance is about trying to develop a community identity where people come to a place, not just driving through a bunch of buildings and streets but there's actually a community there.”

Although Tucker County is fortunate to have these organizations and businesses committed to sustainable development of the destination, a destination management framework was lacking; thus, the authors developed a perceived destination management framework based on the outcomes of the stakeholder analysis in order to define a structure for the roles and responsibilities for destination marketing and management activities. Following a participatory planning and design process facilitated by West Virginia University faculty, the Cultural District Authority developed a performance agenda which includes coordinating management activities under five primary goals for cultural tourism development - protect, connect, enhance, promote, 
and monitor cultural assets. Implementation of the priority activities identified for each of these goals will be coordinated through the stakeholder network. The perceived destination management framework is represented in figure 5 and represents a clear separation of marketing and management roles and responsibilities for the CVB and CDA in hopes that this destination can create a destination management culture that can cope with the decentralized, multi-player, multi-stakeholder nature of the rural tourism business as described by Lane and Kastenholz (2015) and confirmed in this study.

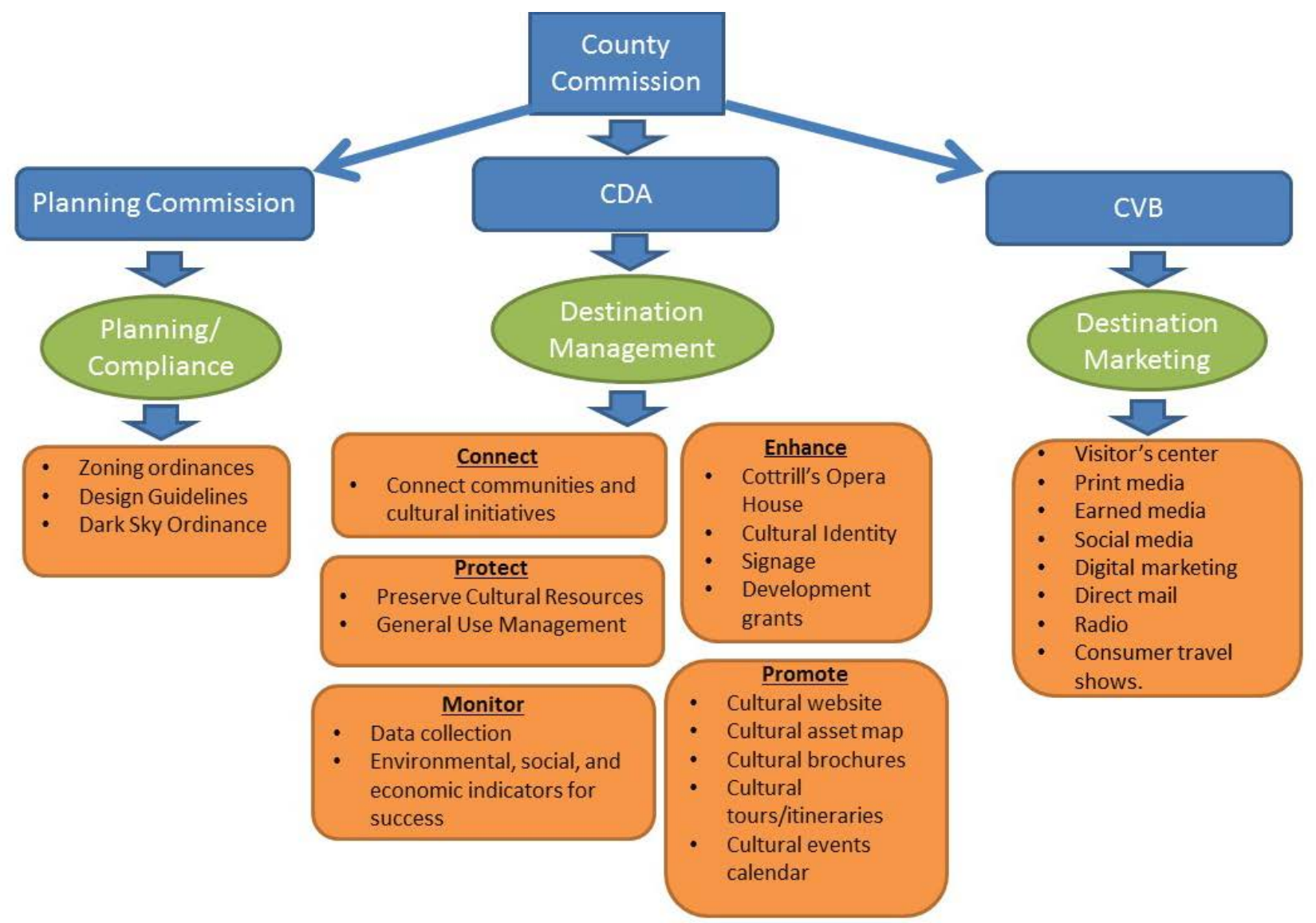

Figure 5 Tucker County Perceived Destination Management Framework

\subsection{Conclusions and Implications}

This study has practical implications for rural destinations and expands upon the body of research on the role of DMO's in rural destinations and the challenges they face. While Presenza 
et al. (2005) encourage DMOs to engage in a combination of marketing and product development and management, the destination audit of Tucker County, WV revealed the need for a new organization with a specific mission to sustainably develop and manage tourism and coordinate activities of the stakeholder network. While the CVB is actively engaged and funded to fulfill the EDM activities of the Presenza et al. (2005) destination management model as described in Table 2, it was clear that they did not view the IDD function as their responsibility or core to their mission. Stakeholders confirmed this and instead of urging the CVB to assume IDD activities as recommended by Presenza et al. (2005), they stressed the need for a new entity to assume this role. This new entity, the Cultural District Authority, formed locally by concerned stakeholders anticipating improved accessibility from metropolitan areas, is being structured to assume the core component of the IDD model of cooperation, coordination, and partnerships among local stakeholders.

After the CDA establishes a sound core competency of stakeholder coordination, members of the stakeholder network are positioned to support the foundation for IDD efforts including quality of the visitor experience (CVB/CDA), visitor servicing (CVB), human resources development (County Commission/CDA/Development Authority), resource stewardship (CDA/Planning Commission), information/research (CDA/West Virginia University), and finance and venture capital (CDA/Community Foundation/Development Authority).

Although a consistent source of funding exists for destination marketing through the hotel-motel tax, destination leadership is challenged to find funding needed to support destination management activities since there are currently very few funding streams from the state dedicated to tourism development, and no local or county tax designed to fund tourism 
development projects. This is consistent with the findings of Pike and Page (2014) that very few DMOs have either the mandate or resources to effectively manage their destination. While a precise legislative or political framework was established to guide the Cultural District Authority, the legislation does not include state funding for development and management, thus, securing internal and external funding for these activities will be critical since long-term financial and technical support is essential if tourism is to play an effective rural development role (Sharpley, 2002).

While this study has shed new light on destination marketing and management roles, challenges identified for rural tourism identified in this study were consistent with those found in the literature including maintaining authenticity and sense of place (The University of Minnesota, 1991; McGehee et al., 2013; George et al., 2009; Plog, 1974, 2001; Rosenow \& Pulshiper, 1979), staffing and quality personnel (Bornhorst et al. 2010), seasonality (Sharpley, 2002), pursuing target markets that minimize negative tourism impact and appreciate the uniqueness of the region (McGehee et al., 2013), coordination, cooperation, and partnerships between businesspersons, local leadership, and rural tourism entrepreneurs (Wilson et al., 2001; Holden, 2010; The University of Minnesota Extension Service, 1991; Pasape et al., 2013), respect for local residents and positive economic impact for the community (McGehee et al., 2013), and economic diversification (The University of Minnesota Extension Service, 1991).

This study explores the challenges of sustainably developing tourism in a rural destination at the development stage of the Butler (1980) Tourism Lifecycle and the potential role for a newly formed destination management organization. It is apparent that stakeholders are proactively trying to resist the development stage pressures of resident dissent for tourists, commercialization, and loss of authenticity or what Plog (2001) described as "many destinations 
follow a typical pattern of uncontrolled tourism development... losing their distinctive character along the way and with the greater number of these attractions the greater probability that they will never go away and will contribute to the decline of the area." While this destination appears to have taken control of its destiny it faces considerable challenges in achieving its goals.

Stakeholders are optimistic and actively engaged in creating and managing what could become a model destination for rural destination management. One stakeholder summarized her perspective about the people and the process underway in Tucker County, WV.

I see opportunities, but I also see the challenges, I think we're on the right path, I think that no matter how we agree or disagree, that in the end, we're going to make decisions that are best for the county, not just for us individually, and so I trust that about the people here.

\subsection{Limitations \& Future Studies}

This study is not without its limitations. While this study revealed a clear delineation of destination marketing and management activities and a perceived destination management framework, additional research to apply the destination management model to other rural destinations should be conducted in order to determine if this delineation is consistent in other destinations or if marketing and management activities are combined activities of a rural DMO as suggested by the literature. Additional research is necessary to further define the structure of the CDA, engage additional stakeholders, and document achievements of the destination management goals over time and determine whether stakeholder roles and activities are consistent or change over time as the destination continues through the stages of the Tourism Lifecycle (Butler, 1980). 
Timur and Getz (2008) suggest that integrating stakeholder and network theories provide a robust foundation for identifying critical stakeholders in destination development, for determining whether identified critical stakeholders have existing relationships with the other members of destination networks and for identifying those organizational stakeholders who should lead in establishing tourism stakeholder networks. Social network analysis can be used to identify "nodes,” or "actors,” which are entities, persons, organizations, or events; “links,” which are the relationships of any kind between the actors; "networks," which are the patterns formed from the combination of all the actors and links within the system; "density,” which is the number of connections between actors within the network; and "centrality." Presenza et al. (2005), suggest that an important assessment of the DMO ability to foster IDD will be directly related to the number and quality of relationships with tourism destination stakeholders and to conduct network analyses to determine the strength of the DMO's position (centrality) in the network vis-à-vis the density of the network.

While this study has shed some light on the number of organizations and their role(s) related to destination management, social network analysis would determine the type and strength of the relationships within the perceived destination management framework. The organizations identified as having a role to play in the network that were identified in this study that should be included in the network analysis are listed in Table 4. Additional analysis to further define the structure of the destination management network including the actors, links, density, and centrality would be a logical next step in guiding the stakeholders of Tucker County, WV toward their vision for sustainable rural tourism. 
Table 4 Stakeholder Network

\begin{tabular}{|c|c|c|c|c|c|c|c|}
\hline \begin{tabular}{|l} 
Destination \\
Management \\
/Marketing
\end{tabular} & Planning & $\begin{array}{l}\text { Communitie } \\
\mathrm{s}\end{array}$ & Recreation & Arts & $\begin{array}{l}\text { Entreprene } \\
\text { urship }\end{array}$ & $\begin{array}{l}\text { Agricultu } \\
\text { re }\end{array}$ & Heritage \\
\hline 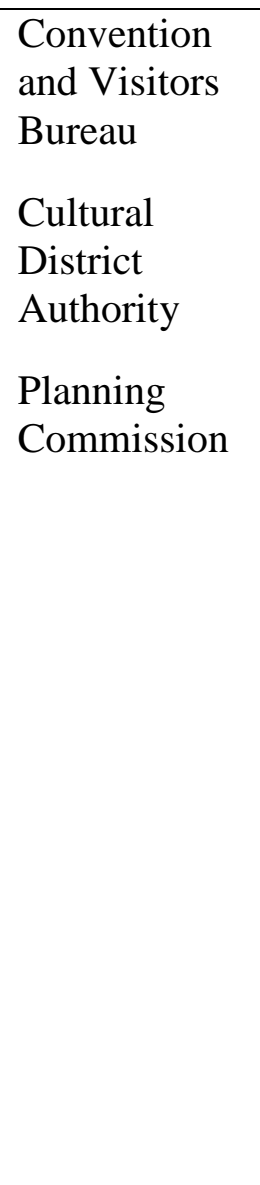 & \begin{tabular}{|l} 
Community \\
Foundation \\
Development \\
Authority \\
Municipalitie \\
s \\
Parks \& \\
Recreation \\
Building \\
Commission \\
Canaan \\
Valley \\
Zoning \\
Board
\end{tabular} & \begin{tabular}{|l} 
PRO \\
OnTRAC \\
Davis \\
Renaissance \\
New \\
Historic \\
Thomas \\
Hendricks- \\
Hambleton \\
Canaan \\
Valley
\end{tabular} & $\begin{array}{l}\text { Heart of the } \\
\text { Highlands } \\
\text { US Forest } \\
\text { Service } \\
\text { NYSF } \\
\text { DNR } \\
\text { CVR } \\
\text { BFSP } \\
\text { New } \\
\text { Historic } \\
\text { Thomas } \\
\text { Blackwater } \\
\text { Bike Assoc. } \\
\text { Friends of } \\
\text { the } \\
\text { Blackwater } \\
\text { Parks \& Rec } \\
\text { Boards }\end{array}$ & $\begin{array}{l}\text { ArtSprin } \\
\mathrm{g} \\
\text { StART }\end{array}$ & $\begin{array}{l}\text { Developme } \\
\text { nt Authority } \\
\text { Eastern CC } \\
\text { WVU } \\
\text { Launch Lab }\end{array}$ & $\begin{array}{l}\text { Food \& } \\
\text { Farm } \\
\text { Initiative }\end{array}$ & $\begin{array}{l}\text { Historic } \\
\text { Landmark } \\
\text { Commission } \\
\text { Historical } \\
\text { Society } \\
\text { Alpine } \\
\text { Heritage } \\
\text { Preservation } \\
\text { Friends of } \\
\text { the } \\
\text { Blackwater } \\
\text { AFHA }\end{array}$ \\
\hline
\end{tabular}




\subsection{References}

About TCF. (2015). The Tucker Community Foundation. Retrieved from http://www.tuckerfoundation.net/

Bonham, C., \& Mak, J. (1996). Private versus public financing of state destination promotion. Journal of Travel Research, 35(2), 3-10.

Bornhorst, T., Ritchie, J. B., \& Sheehan, L. (2010). Determinants of tourism success for DMOs \& destinations: An empirical examination of stakeholders' perspectives. Tourism management, 31(5), 572-589.

Butler, R. W. (1980). The concept of a tourist area cycle of evolution: Implications for management of resources. Canadian Geographer, 24, 5-12.

Canaan Valley Zoning Committee. (1998). Canaan Valley Zoning Ordinance. Retrieved from http://tuckercountycommission.com/wp-content/uploads/2016/05/Canaan-Valley-ZoningOrdinance.pdf

Dore, L., \& Crouch, G. I. (2003). Promoting destinations: An exploratory study of publicity programs used by national tourism organizations. Journal of Vacation Marketing, 9(2), 137151.

Fleischer, A., \& Felsenstein, D. (2000). Support for rural tourism: Does it make a difference?. Annals of Tourism Research, 27(4), 1007-1024.

Fleischer, A., \& Pizam, A. (1997). Rural tourism in Israel. Tourism Management, 18(6), 367372.

Franch, M., \& Martini, U. (2002). Destinations and destination management in the Alps: A proposal for a classification scheme in the light of some ongoing experiences. Paper presented at meeting "Territoires et marchés ème colloque de recherche en tourisme de l'Association française des IUP Tourisme, Hôtellerie et Loisirs", Université de Savoie, Site de Chambery (F), 12-14 settembre.

Gannon, A. (1994). Rural tourism as a factor in rural community economic development for economies in transition. Journal of Sustainable Tourism, 2(1-2), 51-60.

Gartrell, R. (1994). Strategic partnerships. In Destination Marketing for Convention and Visitor Bureaus (2nd ed.). (pp. 230-232) Dubuque, Iowa: Kendall/Hunt Publishing Co.

Gartner, W. (2004). Rural tourism development in the USA. International Journal of Tourism Research, 6(3), 151-164.

Holden, A. (2010). Exploring stakeholders' perceptions of sustainable tourism development in the Annapurna conservation area: issues and challenge. Tourism and Hospitality Planning \& Development, 7(4), 337-351. 
Howie, F. (2003). Managing the tourist destination. London: Continuum.

Lane, B. (1994). What is Rural Tourism? Journal of Sustainable Tourism, 2(1-2). 7-21.

Lane, B. (2009). Thirty years of sustainable tourism: Drivers, progress, problems and the future. In S. Gossling, M.C. Hall, \& D.B. Weaver (Eds.), Sustainable tourism futures: Perspectives on systems, restructuring, and innovations (pp. 19-32). New York and London: Routledge.

Lane, B., \& Kastenholz, E. (2015). Rural tourism: the evolution of practice and research approaches-towards a new generation concept?. Journal of Sustainable Tourism, 23(8-9), 1133-1156.

McGehee, N. G., Boley, B. B., Hallo, J. C., McGee, J. A., Norman, W., Oh, C. O., \& Goetcheus, C. (2013). Doing sustainability: an application of an inter-disciplinary and mixed-method approach to a regional sustainable tourism project. Journal of Sustainable Tourism, 21(3), 355-375.

Organization for Economic Cooperation and Development (1994). Tourism strategies and rural development. Retrieved from http://www.oecd.org/cfe/tourism/2755218.pdf

Our Mission. (2012). Tucker County Development Authority. Retrieved from http://www.tuckerwv.com/about/

Pasape, L., Anderson, W., \& Lindi, G. (2013). Towards sustainable ecotourism through stakeholder collaborations in Tanzania. Journal of Tourism Research \& Hospitality, 2(1).

Pike, S., \& Page, S. J. (2014). Destination Marketing Organizations and destination marketing: A narrative analysis of the literature. Tourism management, 41, 202-227.

Plog, S. (2001). Why destination areas rise and fall in popularity. Cornell Hotel and Restaurant Administration Quarterly, 42(3), 13-24.

Pearce, D. (1992). Tourist organizations. Harlow, Essex, England: Longman Group UK Ltd.

Presenza, A., Sheehan, L., \& Ritchie, J. B. (2005). Towards a model of the roles and activities of destination management organizations. Journal of Hospitality, Tourism and Leisure Science, 3(1), 1-16.

Ritchie, J. B., \& Crouch, G. I. (2003). The competitive destination: A sustainable tourism perspective. Wallingford, Oxon, GBR: CABI.

Runyan, D. (2015) West Virginia Travel Impacts 2000-2014p. Retrieved from https://gotowv.com/industry-information/

Sharpley, R. (2002). Rural tourism and the challenge of tourism diversification: The case of Cyprus. Tourism Management, 23(3), 233-244.

Talburt, S. (2004). Ethnographic responsibility without the" real". The Journal of Higher Education, 75(1), 80-103. 
The University of Minnesota (1991). Rural Tourism Development Training Guide.

Timur, S., \& Getz, D. (2008). A network perspective on managing stakeholders for sustainable urban tourism. International Journal of Contemporary Hospitality Management, 20(4), 445461.

Tucker County Commission. (n.d.). Welcome to the Tucker County Commission. Retrieved from http://tuckercountycommission.com/

United States Census Bureau. (n.d.). Quick Facts Tucker County, West Virginia Retrieved from http://www.census.gov/quickfacts/table/PST045215/54093,00

Volgger, M., \& Pechlaner, H. (2014). Requirements for destination management organizations in destination governance: Understanding DMO success. Tourism Management, 41, 64-75.

Waldo, J. (2015). Tucker County, WV Convention \& Visitors Bureau, Inc. 2015 Annual Report.

Wilson, S., Fesenmaier, D.R., Fesenmaier, J., \& Van Es, J.C. (2001). Factors for Success in Rural Tourism Development. Journal of Travel Research, 40, 132-138.

WVSB561. Assemb. Reg. Sess. 2013. (WV 2013). Tucker County Cultural District Authority Act.

Yin, R. (1994). Case study research: Design and methods. Beverly Hills: Sage.

Yuksel, F., Bramwell, B., \& Yuksel, A. (1999). Stakeholder interviews and tourism planning at Pamukkale, Turkey. Tourism Management, 20(3), 351-360. 


\title{
CHAPTER 3
}

\section{The Effect of Social Capital on Resident Attitudes toward Tourism and Support for Rural Tourism Development}

\begin{abstract}
This paper describes an analysis of the effect of social capital on resident attitudes toward tourism and support for tourism among residents of Tucker County, West Virginia. This study utilized a quantitative research design including a mailed survey to the entire population of residents of Tucker County, West Virginia with a valid mailing address. The survey instrument included Likert scale items designed to measure residents’ attitudes toward tourism development and support for tourism and social capital in the county. Of the 3,621 surveys distributed, 637 resident surveys were completed and returned for a $17.6 \%$ return rate. Data analysis included descriptive analysis, factor analysis, confirmatory factor analysis, structural equation modeling, multi-group analysis, and ANOVA. Results confirms the findings of other studies that concern for the potential environmental and social impacts of tourism and long-term planning have a direct positive effect on support for additional tourism development. In addition to the direct effect of the social and environmental impacts of tourism and long-term planning on support for tourism, this study identified that a common vision and participation in local organizations and informal social groups has a significant direct effect on long term planning and protection of community values and an indirect effect on support for tourism development. In addition, significant differences were identified according to group, stake, and power in the community.

Keywords: rural tourism, sustainable tourism, resident attitudes toward tourism, social capital, support for tourism, structural equation modeling, multi-group analysis.
\end{abstract}




\subsection{Introduction}

Rural destinations face the challenge of developing and promoting attractions for visitors while preserving the rural landscape, presenting complex management and development challenges (Howie, 2003). While the economic benefits of tourism have been well documented and promoted, the development of tourism also incurs varying degrees of impact on destination environments as well as the local residents who act as 'hosts' to tourists (Wall \& Mathieson, 2006). Research has proven that balancing of residents' perceptions of the costs and benefits of

tourism is a major factor in tourist satisfaction and is vital for the success of the tourism industry (Andriotis \& Vaughan, 2003). Many authors have suggested that if local communities perceive the costs of tourism to outweigh the benefits then they will withdraw their support for tourism, threatening its future success and development (Lawson, Williams, Young, \& Cossens, 1998). Social capital is not a new concept, but it is relatively recent in its application to tourism development (McGehee, Lee, O'Bannon, \& Perdue, 2010). Park, Nunkoo, and Yoon (2015) suggest that in order to ensure that tourism policies aiming at fostering positive attitudes among rural communities are fully effective, planners should pay attention to the level of social capital present among local residents. This study sought to identify the relationship between social capital, residents’ attitudes toward tourism, and support for tourism in Tucker County, West Virginia.

\subsection{Literature Review}

\subsubsection{Resident Attitudes toward Tourism}

Local host or resident attitudes and perceptions of rural tourism have been extensively examined in the literature. Authors have argued that residents supportive of tourism are a key ingredient to providing high quality visitor experiences (Fick \& Ritchie, 
1991) and that the attitudes and perceptions of local residents should directly inform tourism planning (Ap, 1992). Studies on residents' attitudes toward tourism development have analyzed socioeconomic factors, spatial factors, economic dependency, resident and community typologies; and theoretical perspectives including community attachment, social exchange, and growth machine theory (Harrill, 2004). The earliest standardized measurement of residents' attitudes toward tourism can be traced back to 1994 when Lankford and Howard developed a 27-item, two-dimensional tourism impact attitude scale (TIAS). Social exchange theory (SET), as a theoretical framework, has also been predominantly adopted by researchers to investigate residents’ attitudes toward tourism development. According to SET, local residents are believed to be "likely to participate in an exchange if they believe that they will gain benefits without incurring unacceptable cost... and subsequently endorse future development in their community” (Gursoy \& Rutherford, 2004). Previous studies have confirmed the social exchange theory by identifying that residents with greater economic dependency on tourism are more likely to have positive attitudes toward tourism (Milman \& Pizam, 1988; Murphy, 2001; Knollenberg, 2011; Um \& Crompton, 1987; Wang \& Pfister, 2008).

Community attachment has been examined in the literature on resident attitudes toward tourism with length of residence the most common variable used for analysis. Um and Crompton (1987), McCool and Martin (1994), and Williams et al. (1995) found that a longer length of residence correlated with more negative attitudes toward impacts, however, Liu and Var, (1986) did not find significant differences in attitudes based on ethnicity and length of residence and Allen et al. (1993) based on length of residence; while Vesey and Dimanche (2000) found that community attachment was positively related to perceptions 
toward tourism with respondents noting the positive contributions toward economic benefit and historic preservation. In a study in Washington, Wang and Pfister (2008) measured community attachment by respondents' length of residence and active membership in civic organizations finding that those who are active in community organizations perceive more benefits from increasing recreation opportunities that those who are not active.

Long, Perdue, and Allen (1990) investigated rural resident tourism perceptions and attitudes by community level of tourism in 28 rural Colorado communities finding that resident attitudes initially increase in favorability with increasing levels of tourism, but achieve a threshold level of development beyond which attitudes become less favorable. In addition, McGehee and Andereck (2004) found that more tourism dependent communities are more likely to agree that tourism has negative impacts. Andereck and Vogt (2000) found that communities in Arizona with differing levels of tourism development have differing attitudes about tourism with respect to community development, quality of life, and negative impacts.

In regard to tourism planning, previous studies have identified that long-term planning has a direct positive effect on support for tourism (Choi \& Murray, 2010; Oviedo-Garcia, Castellanos-Verdugo, \& Martin-Ruiz, 2008). In a study of 12 Arizona communities, McGehee, Andereck, and Vogt (2002) concluded that citizens have limited trust in the ability of the community to plan for tourism and everyone, regardless of personal benefit, believes tourism planning is important.

In addition, a number of studies have also compared multi-stakeholders' perceptions of tourism development. According to Byrd, Bosley and Dronberger, (2009) a clear understanding of the attitudes and interests of stakeholders is a necessary precursor to the planning and management of sustainable tourism. Government officials are more powerful 
than residents in terms of their levels of control of resources and their roles in decision making. Pizam (1978) found that tourism-employed residents or entrepreneurs were more positive than non-tourism employed counterparts in their attitudes toward tourism's economic and social impacts in Cape Cod, Massachusetts. Lankford's (1994) study of the Columbia River gorge region indicated that residents perceived the social and environmental aspects of tourism (e.g., noise, crime, litter) significantly differently than the governmental officials, elected/appointed officials and were less positive about the economic impacts of tourism development than were their governmental counterparts. In addition, Byrd et al. (2009) identified that residents were more likely than governmental officials to perceive the negative impacts of tourism (e.g., increase of crimes, negative effects on the environment, and increase of property taxes) in rural communities in North Carolina. Deng, McGill, Arbogast, and Maumbe (2016) investigated governmental officials’ and local residents’ perceptions of tourism development benefits and costs in the Appalachian Forest Heritage Area identifying that attitudes held by tourism-related residents were more positive than non-tourism related residents and interaction effects exist between tourism status or stake (tourism respondents vs. non-tourism respondents) and social status or power (officials vs. residents) in a way that tourism-related residents are the most positive.

\subsubsection{Resident Support for Tourism Development}

In addition to resident attitudes toward tourism, support for tourism development has been extensively studied in the literature. Studies on residents' support for tourism development have found that support for additional tourism development is positively related to the perceived positive impacts and negatively related to perceived negative impacts (Purdue, Long, \& Allen, 1990; Nunkoo \& Gursoy, 2012; Choi \& Murray, 2010). Long, Perdue, and 
Allen (1990) found that resident support for tourism development initially increases with increasing levels of tourism, but achieves a threshold point beyond which it becomes less favorable and that support for special tourism user fees and taxes increases with increasing levels of tourism development. A study by McGehee and Andereck (2004) concluded that the greater the perceived personal benefit from tourism, the smaller the perceived negative effect of tourism and greater likelihood to support additional tourism development. Andereck and Vogt (2000) and Johnson, Snepenger and Akis (1994) found that tourism attitudes among residents in communities are related to support for development, but the nature of the relationship can vary by community when analyzing clusters of communities within a tourism region.

Choi and Murray (2010) found that long-term planning is directly positively related to support for tourism and Oviedo-Garcia, Castellanos-Verdugo, \& Martin-Ruiz (2008) found that the relationship between tourism development and tourism planning is supported more strongly by residents who do not personally benefit from tourism than by those who personally benefit from tourism. It seems that these citizens acknowledged the negative effects that tourism development might have on their community in the absence of proper planning whereas residents who directly benefitted from tourism activities were less concerned about the negative consequences for the community.

\subsubsection{Social Capital and Tourism}

While several authors have noted the lack of research that analyzes social capital's roles in regional and community tourism development (McGehee et al., 2010; Zhao, Ritchie, \& Echtner, 2011), others consider social capital as a prerequisite for sustainable tourism and community development (Bowles \& Gintis, 2002; Macbeth, Carson, \& Northcote, 2004). Various researchers have identified the elements of engagement, trust, cooperation, collective 
norms, knowledge diffusion, and a sense of shared futures as key to building social capital (Bohm \& Nichol, 1996; Dale, 2001; Etzioni, 2000; Robinson, 2004). Norms can be reinforced through a variety of processes: forming groups, collaborating within and among groups, developing a common view of a shared future, forming or reinforcing collective identity, and engaging in collective action (Flora, Flora, \& Gasteyer, 2016).

A study by Grootaert (1998) identified three key roles of social capital for general economic success within communities: information sharing, coordination of activities, and collective decision-making. All three roles are also key to successful tourism development. A study by Park, Nunkoo, and Yoon (2015) revealed that the relationship between perceived socioeconomic impacts of tourism and community support was found to be moderated by the level of social capital with the relationship stronger for the low social capital group than for the high social capital group. Results also indicated that while social capital can be instrumental to the good governance of tourism and can shape the ways in which residents respond to tourism development, a high level of social capital among community members was found to be not always desirable since it can foster negative attitudes toward tourism. The authors suggest that only if the negative consequences of social capital are recognized and managed can communities be built in ways that contribute to sustainable rural tourism development because social capital can act as an impediment to tourism development if it is not well managed since residents exhibiting high social capital can be very sensitive to the negative impacts of tourism development adversely affecting their satisfaction with the community and their support for tourism development. The authors also suggest that residents exhibiting high social capital who view tourism development skeptically can exert significant pressures on others to conform to group norms, adversely influencing community attitudes to tourism. 
While in many cases strong social capital provides the "glue" for a community, if it is too strong it can constrain those with more creative or unconventional ideas about economic development (Karlsson, 2005; Patterson \& Rodriguez, 2003; Roberts, 2004). If a tourism entrepreneur attempts a start-up of a new or different tourism business, she or he may be sanctioned or branded as an out-cast in the community (McGehee et al., 2010). A study by McGehee et al. (2010) analyzed tourism-related social capital and its relationship with other forms of capital in a four-county region of Virginia, finding that the level of tourism industry involvement had no significant relationship with perceived overall social capital, perceived social capital overall within the region was higher among people who lived longer in the region, and that the longer people lived in the region the more they perceived that social networks for the tourism industry are strong.

The objectives of the study, therefore, are to examine the relationship among various rural tourism development factors in Tucker County, WV with emphasis on resident attitudes toward tourism, social capital, and stakeholder engagement in this rural tourism destination. Therefore, the study aims to assess the effect of social capital and resident attitudes toward tourism development on support for tourism development and how the effect may differ according to socio-demographic variables including length of residency, location of residency, gender, and role in the community.

Based on the above review, the following 6 hypotheses are proposed:

H1: Resident attitudes toward tourism will have a direct effect on support for tourism development.

H2: Social capital will have a direct effect on resident attitudes toward tourism and an indirect effect on support for tourism development. 
H3: The relationship between social capital, attitudes toward tourism, and support for tourism development will vary among communities in Tucker County according to the level of tourism development.

H4: The relationship between social capital, attitudes toward tourism, and support for tourism development will vary in Tucker County according to length of residency.

H5: The relationship between social capital, attitudes toward tourism, and support for tourism development will vary in Tucker County according to gender.

H6: The level of social capital, attitudes toward tourism, and support for tourism development will differ in Tucker County according to role in the community.

\subsection{Methods}

\subsubsection{Questionnaire}

This study utilized a quantitative research design including a mailed survey to the entire population of residents of Tucker County, West Virginia in 2016. The survey instrument included Likert scale items designed to measure residents’ attitudes toward tourism development and support for tourism (18 items) and social capital (17 items) in the county on a 5-point scale where 5 = strongly agree and 1 = strongly disagree. The survey instrument was developed based on existing literature on resident attitudes toward tourism (Gursoy, Jurowski, \& Uysal, 2002; Gursoy \& Rutherford, 2004; Lankford \& Howard, 1994; Nunkoo \& Ramkissoon, 2010), support for tourism development (Nunkoo \& Ramkissoon, 2011; Wang \& Pfister, 2008) and social capital scale (Jones, 2005; Flora, 2004; Onyx \& Bullen, 2000; Park, Nunkoo, \& Yoon, 2015). The survey instrument also included an importance- performance analysis of tourism attributes, ranking of tourism development opportunities, open-ended questions, and demographics.

\subsubsection{Data Collection}

The methodology followed the Dillman, Smyth, and Christian’s (2014) “tailored design method" including two weeks after the questionnaire was mailed to the respondents, a reminder 
postcard was sent, followed by a re-mailing of the entire package to those residents that did not respond within four weeks. Two weeks following, a third mailing of the entire package was sent. The survey, cover letter, and postage paid return envelope were distributed to all residents of Tucker County with a valid mailing address using the US Post Office Every Door Direct Mail program which yielded a total of 3,621 addresses.

\subsubsection{Data Analysis}

Data were analyzed in several stages using SPSS 25 and AMOS 25. First, missing values were removed using listwise deletion. Second, descriptive analysis of skew and kurtosis was conducted to determine normality of the items measuring residents' attitudes toward tourism, support for tourism, and social capital. Third, the items measuring residents’ attitudes toward tourism, support for tourism, and social capital were subjected to an exploratory factor analysis with principal component analysis and varimax rotation with Kaiser normalization. The KaiserMeyer-Olkin (KMO) measure of sampling adequacy and Bartlett's test of sphericity were used to determine the appropriateness of the data for factor analysis. An eigenvalue of 1.00 or more was used for the identification of potential factors. Items with factor loadings below 0.45 were excluded from inclusion in factors (Comrey \& Lee, 2013), as well as items that cross loaded with a factor loading above 0.45 and a loading difference of 0.10 on multiple factors ( $\mathrm{Lu}$, Chow \& Loken, 2016). The Cronbach’s alpha value of 0.70 was used as the threshold for measuring a factor’s reliability (Nunnally, 1978).

Fourth, after identifying the factors, a theoretical model explaining the relationship between residents’ attitudes toward tourism, social capital, and support for tourism was developed. The proposed framework was tested through the use of confirmatory factor analysis using the AMOS software program. To evaluate internal consistency, a Cronbach’s alpha was 
used (Nunnally, 1978). Convergent validity was confirmed by analyzing factor loadings and inter-factor item correlations (Hair et al., 1998). AVE was used to determine discriminant validity as recommended by Fornell and Larker (1981). CR measures the internal consistency of a construct and should be greater than 0.70 while AVE evaluates a constructs validity and should be higher than 0.5 (Fornell \& Larcker, 1981). Convergent validity is confirmed if AVE is higher than 0.5 but lower than CR while discriminant validity is confirmed if AVE is greater than MSV (Fornell \& Larcker, 1981). The ratio of $\chi^{2}$ value over the degrees of freedom (i.e., $\chi^{2} / \mathrm{df}$ ) was used to assess the goodness of fit with a ratio of 5 considered acceptable and below 3 indicating better fit (Wheaton et al., 1977). Global fit indices (GFI’s) include RMSEA (Root Mean Square Error of Approximation, CFI (Comparative Fit Index), and SRMR (Standardized Root Mean Square Residual). A CFI value above 0.95, RMSEA value less than .06 and SRMR values below 0.8 indicate a good fitting model (Hu \& Bentler, 1999). In addition, a measurement invariance test was conducted to assess the equivalence of the measurement model for multiple group comparison for three pairs of groups: between the communities with a high level of tourism vs. communities with a low level of tourism; short term residents vs. long term residents and male vs. female respondents. If the test failed to support the measurement invariance, findings resulting from the model may be misleading (Steenkamp \& Baumgartner, 1998).

Fifth, a structural equation model was developed to understand the effects of selected components of social capital on the attitudes of the respondents toward tourism and support for tourism development and to test hypothesized causal relationships among the variables. Structural equation modeling techniques have increasingly gained popularity and acceptance in tourism and hospitality research since the mid-1990's allowing researchers to deal with complex and multidimensional issues in their research and analyze associations between and among a 
number of dependent and independent variables while accounting for measurement error in the estimation process (Nunkoo \& Ramkissoon, 2012; Choi \& Murray, 2010).

Sixth, a multiple group analysis was conducted to statistically compare the relationship strength in the SEM model for the three pairs of groups. Level of tourism was determined by response to the question "Tourism is well developed in my community". Communities responding above the mean of 2.94 to the question "Tourism is well developed in my community" indicated a high level of tourism ( $\mathrm{N}=244)$ and included the communities of Thomas, Davis, and Canaan Valley. Communities responding below the mean indicated a lowlevel tourism ( $\mathrm{N}=264)$ and included the communities of Parsons, St. George, Hambleton, and Hendricks. Short term residents were residents with a length of residency between 1-30 years (N = 249) and long-term residents were defined as residents residing in the community for 31 or more years $(\mathrm{N}=266)$. The critical ratio $(\mathrm{CR})$ from the pairwise parameter compassions table in AMOS 24 was used to test the significant level of a regression weight in SEM. If CR $>1.96$ or $<$ -1.96 , the difference between two regression weights is significant at or lower than the 0.05 level and if $\mathrm{CR}>1.65$ or $<-1.65$, the difference between two regression weights is significant at or lower than the 0.1 level.

Seventh, a one-way between subjects ANOVA was conducted with each factor mean, calculated from the raw mean scores of factor items, as the dependent variable, and the role in the community as the independent variable. Categories for role in the community included government official or local authority $(\mathrm{N}=27)$, non-profit organization $(\mathrm{N}=53)$, tourism business owner or employed in tourism $(\mathrm{N}=64)$, non-tourism business owner or non-tourism related employment $(\mathrm{N}=88)$, and resident $(\mathrm{N}=264)$. If a significant main effect was present, then pairwise comparisons was conducted using ANOVA. 


\subsection{Results}

\subsubsection{Socio-demographic characteristics of respondents}

Of the 3,621 surveys distributed, 637 resident surveys were completed and returned for a 17.6\% return rate. Following listwise deletion the effective sample size was 529. Table 5 lists the demographic breakdown of the survey sample. As shown, females (57.1\%) outnumbered males (42.9\%). A majority of respondents were 51 years or older (72.3\%). Education levels varied with $44.6 \%$ (high school degree or some college) and 50\% (undergraduate or graduate degree). Fifty-eight percent of respondents had an annual family income of less than $\$ 60,000$ and 53.4\% have lived in Tucker County for 31 years or more. Forty-six percent of respondents live in the communities of Davis, Thomas, and Canaan Valley, "on top of the mountain” where the majority of tourism activity and attractions are concentrated, while $53 \%$ of respondents live in the communities of St. George/Parsons, Hambleton/Hendricks, Red Creek, and Dry Fork which are located in the Cheat River valley.

The demographic breakdown of the survey sample is consistent with the demographic breakdown of the resident population described in section 1.2 and table 1 . The male/female ratio of the local population was a little closer than the survey sample at $49.8 \%$ female and $50.2 \%$ male. Tucker County has an older population with $46.7 \%$ above age 50 with $72.3 \%$ of the survey sample above age 50. Less than half of the local population (37.2\%) have attended college with $72 \%$ of the survey sample attending some college and $46.4 \%$ have annual family income of less than $\$ 40,000$ which is consistent with the survey sample. Sixty-six percent of local residents have lived in their current residence for 17 or more years with $64.9 \%$ of survey respondents having lived in Tucker County for 21 or more years. 
Table 5 Socio-demographic characteristics of the survey sample following listwise deletion ( $\mathrm{n}=$ 529)

\begin{tabular}{|c|c|c|}
\hline \multirow[b]{2}{*}{ Variable } & \multicolumn{2}{|c|}{ Proportion of the sample } \\
\hline & Frequency $(n)$ & Percentage (\%) \\
\hline \multicolumn{3}{|l|}{ Gender } \\
\hline Female & 296 & 57.1 \\
\hline Male & 222 & 42.9 \\
\hline Missing & 11 & 2.1 \\
\hline \multicolumn{3}{|l|}{ Age } \\
\hline 1 to 24 & 6 & 1.1 \\
\hline 25 to 34 & 41 & 7.8 \\
\hline 35 to 44 & 51 & 9.6 \\
\hline 45 to 50 & 41 & 7.8 \\
\hline 51 to 60 & 113 & 21.4 \\
\hline 61 to 69 & 155 & 29.3 \\
\hline $70+$ & 114 & 21.6 \\
\hline No Response & 8 & 1.5 \\
\hline \multicolumn{3}{|l|}{ Education } \\
\hline Less than high school & 17 & 3.2 \\
\hline High school & 120 & 22.7 \\
\hline Some college & 116 & 21.9 \\
\hline Undergraduate & 124 & 23.4 \\
\hline Graduate & 141 & 26.7 \\
\hline No Response & 11 & 2.1 \\
\hline \multicolumn{3}{|l|}{ Income } \\
\hline Less than $\$ 20,000$ & 72 & 13.6 \\
\hline$\$ 20,001-\$ 40,000$ & 128 & 24.2 \\
\hline$\$ 40,001-\$ 60,000$ & 106 & 20.0 \\
\hline$\$ 60,001-\$ 80,000$ & 56 & 10.6 \\
\hline$\$ 80,001-\$ 100,000$ & 46 & 8.7 \\
\hline More than $\$ 100,000$ & 68 & 12.9 \\
\hline No Response & 53 & 10 \\
\hline
\end{tabular}


Table 5 (continued)

\begin{tabular}{lrr}
\hline Length of Residency & 18 & \\
1 year or less & 42 & 3.1 \\
2 to 5 years & 44 & 7.9 \\
6 to 10 years & 45 & 8.2 \\
11 to 15 years & 42 & 8.2 \\
16 to 20 years & 58 & 7.7 \\
21 to 30 years & 70 & 11.5 \\
31 to 40 years & 196 & 13.8 \\
$\quad 41$ or more years & & 39.6 \\
Community of Residency & 74 & \\
Thomas & 69 & 14.0 \\
Davis & 101 & 13.0 \\
Canaan Valley & 207 & 19.1 \\
St. George/Parsons & 57 & 39.1 \\
Hambleton/Hendricks & 9 & 10.8 \\
Red Creek & 8 & 1.7 \\
Dry Fork & 4 & 0.8 \\
No Response & & \\
\hline
\end{tabular}

\subsubsection{Factor analysis}

A KMO value of .94 and Bartlett's test of sphericity value off $12273.39(p<.001)$

indicated that the data were suitable for factor analysis. The analysis yielded a total of six factors with eigenvalues greater than 1 which explained a total of $66 \%$ of the variance for the entire set of variables (see Table 6). Only five of the six identified factors were utilized for this analysis because there was only one item loading on Factor 6. This item, "Tourism is well developed in my community", had a mean of $2.91(S D=1.12)$. This item needs to be further reviewed and potentially redesigned. Items exhibiting low factor loadings $(\leq .45)$, high cross loadings $(<.10$ difference in factor loadings), or low communalities $(\leq .40)$ were removed. When items loaded high on more than one factor, the individual item statement was examined to determine the inclusion in the specific factor. It is our recommendation that items with high loadings on more than one factor are further examined for potential improvement. To evaluate internal 
consistency, a Cronbach’s alpha was chosen because the items are multidimensional (Nunnally, 1978).

Factor 1 was labeled trust $(N=12, M=3.83, S D=.83, \alpha=.89)$ and included items referring to trust, safety, acceptance, communication, social networks, and support for one another. This factor explained 32\% of the variance. Factor 2 was labeled support $(N=9, M=$ 3.38, $S D=1.05, \alpha=.93$ ) and included items referring to support for tourism development and positive impacts of tourism development. This factor explained an additional $19 \%$ of variance. Factor 3 was labeled impacts $(N=5, M=2.92, S D=.96, \alpha=.80)$ and included items referring to the potential social and environmental impacts of tourism. This factor explained an additional $6 \%$ of variance. Factor 4 was labeled vision $(N=2, M=3.38, S D=.89, \alpha=.67)$ and included items referring to involvement in social groups and establishing a common vision. This factor explained an additional $4 \%$ of variance. Factor 5 was labeled protection $(N=2, M=4.44, S D=$ $.74, \alpha=.65)$ and included items referring to the protection of community values and long-term planning and managed growth. This factor explained an additional 3\% of variance. 
Variance $^{\mathrm{a}}$

\begin{tabular}{|c|c|c|c|c|c|c|}
\hline Factor/Item & Loading & M & SD & Eigenvalue & (\%) & Alpha \\
\hline Factor 1: Trust & & 3.83 & .83 & 11.045 & 31.558 & .933 \\
\hline I am happy to help my community & .625 & 4.21 & .95 & & & \\
\hline $\begin{array}{l}\text { Residents in my community get along } \\
\text { well together }\end{array}$ & .823 & 3.82 & 1.00 & & & \\
\hline $\begin{array}{l}\text { I feel accepted as a valued resident of } \\
\text { my community }\end{array}$ & .842 & 3.84 & 1.07 & & & \\
\hline $\begin{array}{l}\text { Residents in my community assist one } \\
\text { another in times of need }\end{array}$ & .814 & 4.37 & .93 & & & \\
\hline $\begin{array}{l}\text { Different opinions are valued in my } \\
\text { community }\end{array}$ & .644 & 3.44 & 1.12 & & & \\
\hline $\begin{array}{l}\text { Residents in my community volunteer } \\
\text { to support community events }\end{array}$ & .622 & 3.96 & .94 & & & \\
\hline $\begin{array}{l}\text { Residents in my community trust each } \\
\text { other }\end{array}$ & .778 & 3.67 & 1.06 & & & \\
\hline $\begin{array}{l}\text { If I have a problem there is someone } \\
\text { who will help }\end{array}$ & .805 & 3.98 & 1.09 & & & \\
\hline I feel safe in my community & .736 & 4.37 & .91 & & & \\
\hline $\begin{array}{l}\text { I often do things for other residents of } \\
\text { my community expecting nothing in } \\
\text { return }\end{array}$ & .626 & 4.22 & .92 & & & \\
\hline $\begin{array}{l}\text { There are strong social networks in my } \\
\text { community }\end{array}$ & .636 & 3.61 & 1.06 & & & \\
\hline $\begin{array}{l}\text { I regularly communicate with people in } \\
\text { my community }\end{array}$ & .685 & 3.77 & 1.10 & & & \\
\hline Factor 2: Support & & 3.38 & 1.05 & 6.500 & 18.572 & .936 \\
\hline $\begin{array}{l}\text { My community has great potential to } \\
\text { develop tourism }\end{array}$ & .516 & 3.76 & 1.14 & & & \\
\hline $\begin{array}{l}\text { Tourism development will provide } \\
\text { more economic opportunities for } \\
\text { local people }\end{array}$ & .720 & 3.82 & 1.24 & & & \\
\hline $\begin{array}{l}\text { I support tourism development as } \\
\text { having a vital role in my community }\end{array}$ & .750 & 3.75 & 1.23 & & & \\
\hline $\begin{array}{l}\text { I support taxes for tourism } \\
\text { development }\end{array}$ & .762 & 2.79 & 1.27 & & & \\
\hline
\end{tabular}


Table 6 (continued)

\begin{tabular}{|c|c|c|c|c|c|c|}
\hline $\begin{array}{l}\text { Tourism will improve the wellbeing of } \\
\text { my community }\end{array}$ & .840 & 3.27 & 1.21 & & & \\
\hline $\begin{array}{l}\text { The quality of public services will } \\
\text { improve due to tourism }\end{array}$ & .803 & 3.33 & 1.22 & & & \\
\hline $\begin{array}{l}\text { My community should invest in } \\
\text { tourism development }\end{array}$ & .836 & 3.43 & 1.28 & & & \\
\hline $\begin{array}{l}\text { My community should do more to } \\
\text { promote its tourism assets to visitors }\end{array}$ & .765 & 3.70 & 1.23 & & & \\
\hline Factor 3: Impacts & & 2.92 & .96 & 2.051 & 5.859 & .801 \\
\hline $\begin{array}{l}\text { My community should discourage } \\
\text { more intensive development of } \\
\text { facilities, services, and attractions for } \\
\text { tourists }\end{array}$ & .621 & 2.34 & 1.31 & & & \\
\hline $\begin{array}{l}\text { An increase in tourism will increase } \\
\text { the cost of living in my community }\end{array}$ & .683 & 3.15 & 1.22 & & & \\
\hline $\begin{array}{l}\text { An increase in tourism will lead to } \\
\text { unacceptable amounts of traffic, } \\
\text { crime, and pollution }\end{array}$ & .742 & 2.85 & 1.27 & & & \\
\hline $\begin{array}{l}\text { Tourism development will only } \\
\text { produce low-paying service jobs }\end{array}$ & .713 & 3.22 & 1.22 & & & \\
\hline $\begin{array}{l}\text { An increase in tourism will lead to } \\
\text { crowding of outdoor recreation, } \\
\text { historic, and cultural sites/attractions }\end{array}$ & .674 & 3.09 & 1.18 & & & \\
\hline Factor 4: Vision & & 3.38 & .89 & 1.415 & 4.042 & .676 \\
\hline $\begin{array}{l}\text { Residents in my community are } \\
\text { involved in local organizations and } \\
\text { informal social groups }\end{array}$ & .673 & 3.67 & .97 & & & \\
\hline $\begin{array}{l}\text { There is a common vision in my } \\
\text { community }\end{array}$ & .618 & 3.09 & 1.08 & & & \\
\hline Factor 5: Planning & & 4.44 & .74 & 1.003 & 2.866 & .648 \\
\hline $\begin{array}{l}\text { It is important that community values } \\
\text { are protected when tourism is } \\
\text { developed }\end{array}$ & .740 & 4.49 & .84 & & & \\
\hline $\begin{array}{l}\text { Long-term planning and managed } \\
\text { growth is important to control any } \\
\text { negative impacts of tourism }\end{array}$ & .748 & 4.40 & .88 & & & \\
\hline
\end{tabular}

Kaiser-Myer-Olkin measure $=.943$; Bartlett's Test $=12273.394(\mathrm{p}<.001)$.

a. Total variance explained $=65.978$ 


\subsubsection{Measurement model}

Following listwise deletion to remove items with missing data, an effective sample size of $\mathrm{N}=529$ was achieved corresponding to $17 \%$ missing data. Descriptive analysis of skew and kurtosis confirmed a reasonable degree of normality. This model has been improved by specifying the relationships in the model, testing the model fit and improving, if necessary, and estimating path coefficients for the final model. Table 8 shows the GFI's for the hypothesized structural model. The chi square goodness of fit statistic assesses a likelihood ratio test statistic that tests the fit between the restricted hypothesized model and unrestricted sample data, and the chi square statistic value shows the result is statistically significant $(p<.01)$. However, this finding is not unusual with large sample sizes. When tested models use large sample sizes they often produce a large chi square statistic that could reject a good fitting model.

The measurement model (Figure 2) was evaluated and revised until a theoretically meaningful and statistically acceptable model was achieved. Although the $p$ value is less than .001, the data fit the mode well as indicated by other model fit parameters (i.e., the ratio of

$x^{2} /$ degree of freedom $=2.85$; CFI $=.952 ;$ RMSEA $=.059$ 90\% CI $[.052, .066]$; and SRMR $\left.=.054\right)$. 


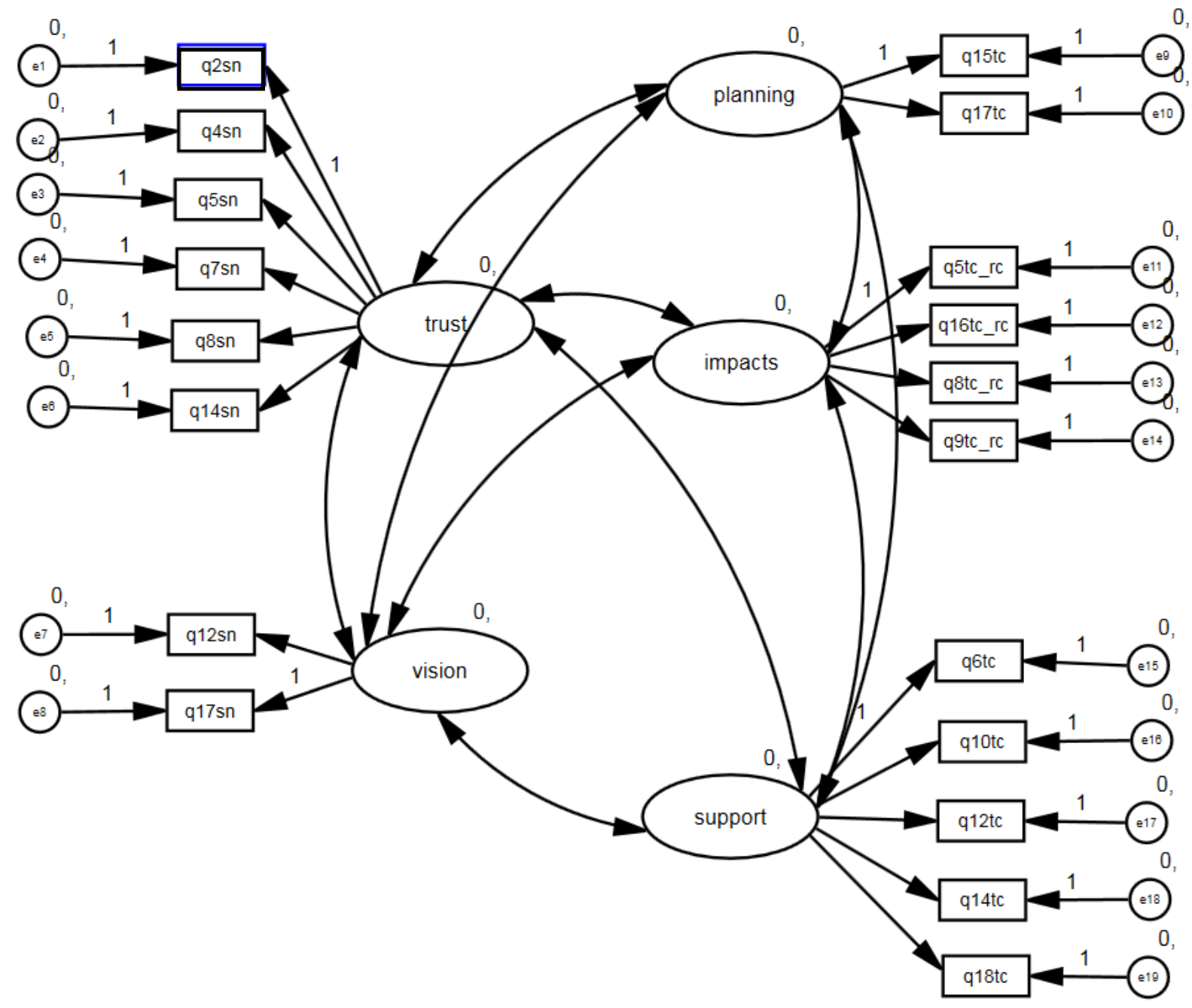

Figure 6 Measurement Model 
To evaluate internal consistency, a Cronbach’s alpha was used with all factors at acceptable levels (Nunnally, 1978). Convergent validity was confirmed by analyzing factor loadings and inter-factor item correlations (Hair et al., 1998). AVE was used to determine discriminant validity as recommended by Fornell and Larker (1981) with all values in acceptable ranges. In addition, all factor loadings that were statistically significant at the 0.01 level indicating that all the measures demonstrated adequate discriminant validity. However, alpha was greater than 0.7 for vision and planning, CR less than 0.7 for vision, AVE less than 0.5 for vision and impacts but lower than CR, and MSV greater than AVE for vision and the square root of AVE less than inter-construct correlation for vision. The results from the CFA are presented in Table 7. 
Table 7 Measurement Model

\begin{tabular}{|c|c|c|c|c|c|c|}
\hline Constructs and Indicators & Parameter & Mean & $\begin{array}{l}\text { Standard } \\
\text { estimate }\end{array}$ & $\begin{array}{c}\text { Standard } \\
\text { error }\end{array}$ & $t$-value & $\begin{array}{l}\alpha / \mathrm{CR} / \mathrm{AVE} / \\
\mathrm{MSV} / \mathrm{ASV}\end{array}$ \\
\hline Trust & & & & & & $\begin{array}{c}0.89 / 0.89 / 0.58 / \\
0.55 / 0.15\end{array}$ \\
\hline $\begin{array}{l}\text { Residents in my community get } \\
\text { along well together }\end{array}$ & q2sn & 3.82 & .811 & & & \\
\hline $\begin{array}{l}\text { Residents in my community assist } \\
\text { one another in times of need }\end{array}$ & q4sn & 4.37 & .781 & .045 & 19.960 & \\
\hline $\begin{array}{l}\text { Different opinions are valued in my } \\
\text { community }\end{array}$ & q5sn & 3.44 & .688 & .056 & 16.944 & \\
\hline $\begin{array}{l}\text { Residents in my community trust } \\
\text { each other }\end{array}$ & q7sn & 3.67 & .835 & .050 & 21.848 & \\
\hline $\begin{array}{l}\text { If I have a problem there is } \\
\text { someone who will help }\end{array}$ & q8sn & 3.98 & .807 & .052 & 20.867 & \\
\hline $\begin{array}{l}\text { I regularly communicate with } \\
\text { people in my community }\end{array}$ & q14sn & 3.77 & .919 & .055 & 16.712 & \\
\hline Vision & & & & & & $\begin{array}{c}0.67 / 0.59 / 0.42 / \\
0.55 / 0.16\end{array}$ \\
\hline $\begin{array}{l}\text { Residents in my community are } \\
\text { involved in local organizations } \\
\text { and informal social groups }\end{array}$ & q12sn & 3.67 & .698 & & & \\
\hline $\begin{array}{l}\text { There is a common vision in my } \\
\text { community }\end{array}$ & q17sn & 3.09 & .736 & & & \\
\hline Planning & & & & & & $\begin{array}{c}0.65 / 0.74 / 0.55 / \\
0.09 / 0.05\end{array}$ \\
\hline $\begin{array}{l}\text { It is important that community } \\
\text { values are protected when } \\
\text { tourism is developed }\end{array}$ & q15tc & 4.49 & .637 & & & \\
\hline $\begin{array}{l}\text { Long-term planning and managed } \\
\text { growth is important to control } \\
\text { any negative impacts of tourism }\end{array}$ & $\mathrm{q} 17 \mathrm{tc}$ & 4.40 & .753 & & & \\
\hline Impacts & & & & & & $\begin{array}{c}0.80 / 0.79 / 0.49 / \\
0.28 / 0.072\end{array}$ \\
\hline $\begin{array}{l}\text { An increase in tourism will } \\
\text { increase the cost of living in my } \\
\text { community }\end{array}$ & q5tc_rc & 3.15 & .624 & & & \\
\hline
\end{tabular}


Table 7 (continued)

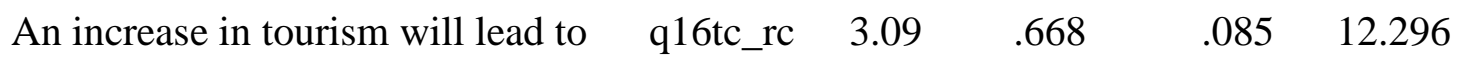

crowding of outdoor recreation,

historic, and cultural

sites/attractions

$\begin{array}{llllll}\text { An increase in tourism will lead to } & \text { q8tc_rc } & 2.85 & .838 & .100 & 14.062\end{array}$

unacceptable amounts of traffic,

crime, and pollution

Tourism development will only

q9tc_rc $\quad 3.22 \quad .675$

.088

produce low-paying service jobs

Support

$0.91 / 0.89 / 0.63 /$

$0.28 / 0.11$

$\begin{array}{llll}\text { I support tourism development as } & \text { q6tc } & 3.75 \quad & .850\end{array}$

having a vital role in my

community

$\begin{array}{llllll}\text { I support taxes for tourism } & \text { q10tc } & 2.79 & .561 & .049 & 13.868\end{array}$

development

Tourism will improve the

wellbeing of my community

My community should invest in

tourism development

$\begin{array}{llllll}\text { My community should do more to } & \text { q18tc } & 3.70 & .869 & .039 & 26.004\end{array}$

promote its tourism assets to

visitors

Note: AVE = Average Variance Extracted, CR = Composite Reliability; MSV = Maximum

Shared Variance; ASV = Average Shared Variance

$\chi^{2}$ to $\mathrm{D} / \mathrm{F}$ ratio $=2.851 ; \mathrm{CFI}=.952 ; \mathrm{RMSEA}=.059,90 \%$ CI $[.052, .066] ; \mathrm{SRMR}=.054$ 


\subsubsection{Structural Model}

\subsubsection{Overall structural model}

Figure 7 presents the overall structural equation model. The results of the path analysis are presented in Table 8 including the model fit parameters and the direct, indirect, and total effects. As illustrated in the table, the model fit the data very well with the ratio $x^{2} /$ degree of freedom less than 5, CFI greater than .95, and RMSEA and SRMR less than .06. Results of the path analysis partially confirmed the study's hypotheses. Planning and impacts had a direct positive effect on support at the significance level of .001. While vision did not have a direct effect on impacts or support, it had a direct positive effect on planning at the significance level of .05 and an indirect positive effect on support. Trust did not have a significant effect on planning, impacts, or support. Resident attitudes toward the potential social and environmental impacts of tourism had a strong direct effect on their support for tourism development. Concern about the environmental and social impacts of tourism had a strong positive effect on support for tourism development. Resident attitudes toward planning and community values had a direct positive effect on resident support for tourism development. 


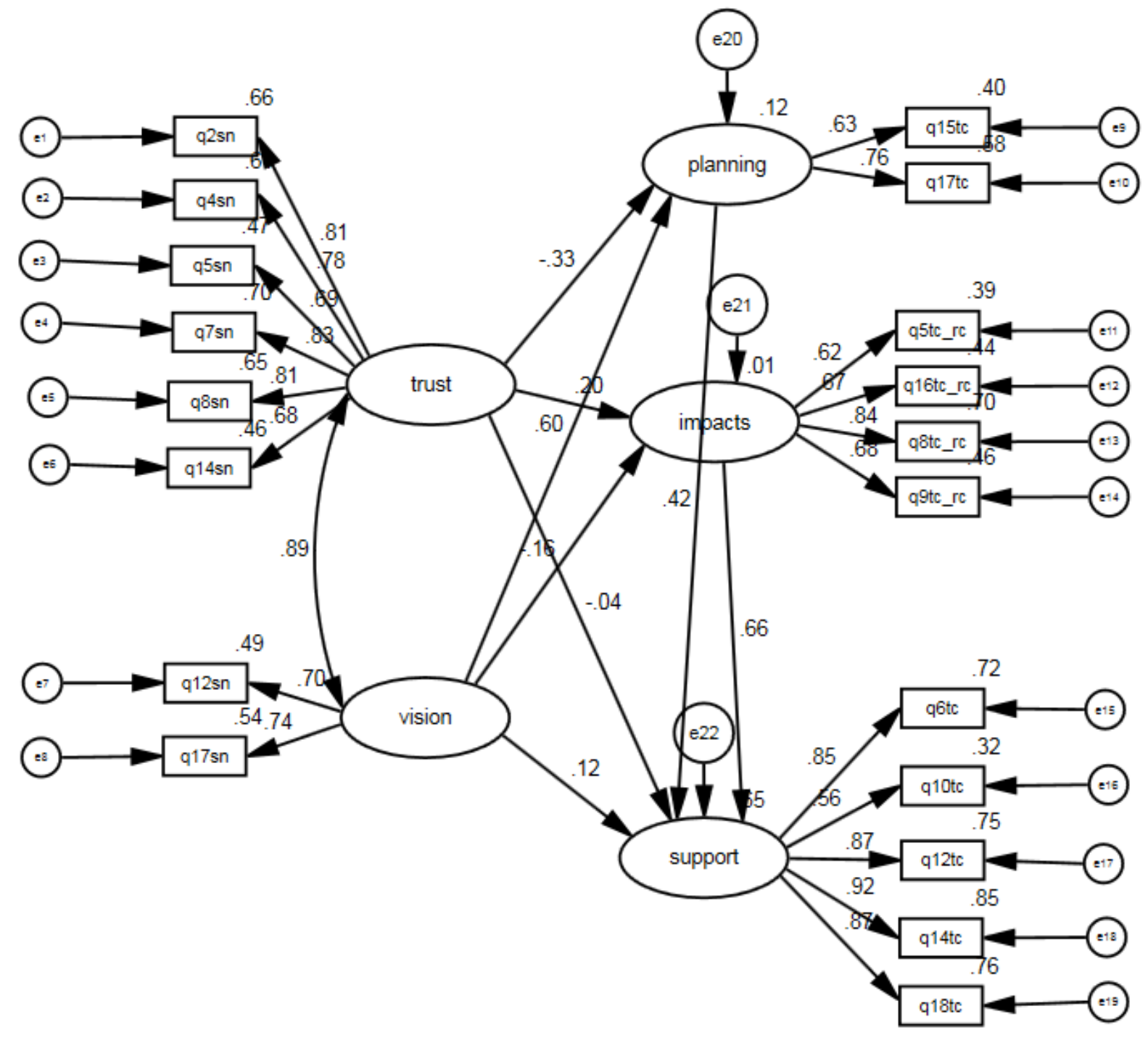

Figure 7 Structural Model 
Table 8 Path Model

\begin{tabular}{lcc}
\hline & Standardized $\beta$ & $t$ \\
\hline vision $\rightarrow$ planning & .600 & $2.323^{*}$ \\
vision $\rightarrow$ impacts & -.159 & -.806 \\
trust $\rightarrow$ impacts & .195 & 1.039 \\
trust $\rightarrow$ planning & -.328 & -1.368 \\
vision $\rightarrow$ support & .120 & .762 \\
trust $\rightarrow$ support & -.035 & -.244 \\
planning $\rightarrow$ support & .425 & $7.524^{* *}$ \\
impacts $\rightarrow$ support & .662 & $11.837^{* *}$ \\
\hline$\chi^{2}=406, \mathrm{df}=143 ;$ CFI $=.952 ;$ RMSEA $=.059 ;$ SRMR $=.054$ \\
${ }^{*} p<.05$ \\
$* * p<.001$
\end{tabular}

\subsubsection{Multiple group comparison using SEM}

The SEM multiple group analysis presented in Tables 9-14 indicates that there were no significant differences in path coefficients between the high tourism communities and the low tourism communities. The path linking impacts and support between short term and long term residents was almost significant at the $p<0.1$ level ( $p=.105$ ) with the relationship between the two variables being stronger for short term residents than for long term residents. The path linking impacts and support between male and female residents was significant at the $p<0.1$ level ( $p=.065)$ with the relationship between the two variables being stronger for male residents than for female residents. 
Table 9 Measurement invariance test between male and female.

\begin{tabular}{lccccc}
\hline & Chi- & & & & \\
& square & df & $\chi^{2} /$ df & CFI & RMSEA \\
\hline Unconstrained measurement model & 574.5 & 286 & 2.01 & 0.95 & 0.044 \\
Constrained measurement model & 594.2 & 308 & 1.93 & 0.95 & 0.042 \\
Chi-square difference & $19.6^{*}$ & 22 & & & \\
\hline
\end{tabular}

${ }^{*} p>.05$.

Table 10 Direct effect, indirect effect, and total effect (male and female).

\begin{tabular}{lcccc}
\hline \multicolumn{1}{c}{ Path } & Direct effect & Indirect effect & Total effect & Group \\
\hline vision $\rightarrow$ planning & 0.99 & - & 0.99 & male \\
& 0.44 & - & 0.44 & female \\
vision $\rightarrow$ impacts & -0.21 & - & -0.21 & male \\
& -0.09 & - & -0.09 & female \\
trust $\rightarrow$ impacts & 0.22 & - & 0.22 & male \\
& 0.09 & - & 0.09 & female \\
trust $\rightarrow$ planning & -0.74 & - & -0.74 & male \\
& -0.08 & - & -0.08 & female \\
vision $\rightarrow$ support & 0.30 & 0.21 & 0.51 & male \\
& 0.13 & 0.12 & 0.25 & female \\
trust $\rightarrow$ support & -0.17 & -0.11 & -0.28 & male \\
& -0.07 & 0.03 & -0.04 & female \\
planning $\rightarrow$ support & 0.36 & - & 0.36 & male \\
& 0.41 & - & 0.41 & female \\
impacts $\rightarrow$ support & $0.71^{*}$ & - & 0.71 & male \\
& $0.64^{*}$ & - & 0.64 & female \\
\hline
\end{tabular}

$\chi^{2}$ to D/F ratio $=2.01 ;$ CFI $=.944 ;$ RMSEA $=.044,90 \%$ CI [.039,.05]; SRMR $=.061$

${ }^{*} p<.01, * * p<.05, * * * p<.001$. 
Table 11 Measurement invariance test between high tourism and low tourism.

\begin{tabular}{lccccccc}
\hline & $\begin{array}{c}\text { Chi- } \\
\text { square }\end{array}$ & df & $\chi^{2} /$ df & CFI & RMSEA & $\begin{array}{c}\text { 95\% Confidence } \\
\text { Interval }\end{array}$ \\
\hline & & & & & & $\begin{array}{c}\text { Upper } \\
\text { bound }\end{array}$ & $\begin{array}{c}\text { Lower } \\
\text { Bound }\end{array}$ \\
\hline Unconstrained measurement model & 601.5 & 286 & 2.10 & 0.94 & 0.047 & & \\
Constrained measurement model & 619.7 & 308 & 2.01 & 0.94 & 0.045 & & \\
Chi-square difference & $18.1^{*}$ & 22 & & & & & \\
\hline
\end{tabular}

$* p>.05$.

Table 12 Direct effect, indirect effect, and total effect (high tourism and low tourism).

\begin{tabular}{|c|c|c|c|c|}
\hline Path & Direct effect & Indirect effect & Total effect & Group \\
\hline \multirow{2}{*}{ vision $\rightarrow$ planning } & 0.54 & - & 0.54 & high \\
\hline & 0.48 & - & 0.48 & low \\
\hline \multirow[t]{2}{*}{ vision $\rightarrow$ impacts } & -0.05 & - & -0.05 & high \\
\hline & -0.07 & - & -0.07 & low \\
\hline \multirow[t]{2}{*}{ trust $\rightarrow$ impacts } & 0.08 & - & 0.08 & high \\
\hline & 0.09 & - & 0.09 & low \\
\hline \multirow[t]{2}{*}{ trust $\rightarrow$ planning } & -0.28 & - & -0.28 & high \\
\hline & -0.21 & - & -0.21 & low \\
\hline \multirow[t]{2}{*}{ vision $\rightarrow$ support } & 0.16 & 0.17 & 0.32 & high \\
\hline & 0.17 & 0.18 & 0.34 & low \\
\hline \multirow[t]{2}{*}{ trust $\rightarrow$ support } & -0.06 & -0.05 & -0.11 & high \\
\hline & -0.06 & -0.04 & -0.10 & low \\
\hline \multirow[t]{2}{*}{ planning $\rightarrow$ support } & 0.37 & - & 0.37 & high \\
\hline & 0.45 & - & 0.45 & low \\
\hline \multirow[t]{2}{*}{ impacts $\rightarrow$ support } & 0.74 & - & 0.74 & high \\
\hline & 0.58 & - & 0.58 & low \\
\hline
\end{tabular}


Table 13 Measurement invariance test between short term residents and long term residents.

\begin{tabular}{lccccc}
\hline & Chi- & & & & \\
& square & df & $\chi^{2} / \mathrm{df}$ & CFI & RMSEA \\
\hline Unconstrained measurement model & 535.2 & 286 & 1.87 & 0.95 & 0.041 \\
Constrained measurement model & 568.11 & 308 & 1.85 & 0.95 & 0.041 \\
Chi-square difference & $32.9^{*}$ & 22 & & & \\
\hline
\end{tabular}
${ }^{*} p>.05$.

Table 14 Direct effect, indirect effect, and total effect (short term residents and long term residents).

\begin{tabular}{lcccc}
\hline \multicolumn{1}{c}{ Path } & Direct effect & Indirect effect & Total effect & Group \\
\hline vision $\rightarrow$ planning & 0.99 & - & 0.99 & short \\
& 0.31 & - & 0.31 & long \\
vision $\rightarrow$ impacts & -0.17 & - & -0.17 & short \\
& -0.17 & - & -0.17 & long \\
trust $\rightarrow$ impacts & 0.17 & - & 0.17 & short \\
& 0.21 & - & 0.21 & long \\
trust $\rightarrow$ planning & -0.64 & - & -0.64 & short \\
& -0.07 & - & -0.07 & long \\
vision $\rightarrow$ support & -0.21 & -0.38 & 0.17 & short \\
& 0.27 & -0.001 & 0.26 & long \\
trust $\rightarrow$ support & 0.22 & -0.21 & 0.02 & short \\
& -0.17 & 0.11 & -0.05 & long \\
planning $\rightarrow$ support & 0.51 & - & 0.51 & short \\
& 0.35 & - & 0.35 & long \\
impacts $\rightarrow$ support & 0.72 & - & 0.72 & short \\
& 0.66 & - & 0.66 & long \\
\hline
\end{tabular}

$\chi 2$ to $\mathrm{D} / \mathrm{F}$ ratio $=1.87 ; \mathrm{CFI}=.951 ; \mathrm{RMSEA}=.041,90 \%$ CI [.036,.047]; SRMR $=.061$ ${ }^{*} p<.01, * * p<.05, * * * p<.001$.

\subsubsection{ANOVA}

Before an analysis of variance is conducted, the assumption of homogeneity of variance is tested. Of the total five ANOVA tests, Vision, Planning, and Impacts met the assumption of equal variances ( $p>.05$ for the Levene's test of equality of error variances), Trust and Support did not meet the assumption of equal variances ( $p<.05$ for the Levene's test of equality of error variances), however the F statistic is generally robust to violations of the assumption of as long as group sizes are equal (source), thus suggesting that the assumption of homogeneity is 
basically not violated. The test of between group effects is presented in Table 15. There was a significant effect of role in the community on Trust at the $p<.05$ level $[\mathrm{F}(4,491)=3.253, p=$ .012], there was a significant effect of role in the community on Vision at the $p<.05$ level $[F(4,491)=2.964, p=.019]$, and there was a significant effect of role in the community on Support at the $p<.05$ level $[\mathrm{F}(4,491)=3.991, p=.003]$.

Table 15 Test of Between Group Effects

\begin{tabular}{|c|c|c|c|c|c|c|}
\hline & & $\begin{array}{l}\text { Sum of } \\
\text { Squares }\end{array}$ & df & $\begin{array}{l}\text { Mean } \\
\text { Square }\end{array}$ & $\mathrm{F}$ & Sig. \\
\hline \multirow[t]{4}{*}{ Trust } & Between & 8.855 & 4 & 2.214 & 3.253 & $0.012^{*}$ \\
\hline & Groups & & & & & \\
\hline & Within Groups & 334.167 & 491 & 0.681 & & \\
\hline & Total & 343.022 & 495 & & & \\
\hline \multirow[t]{3}{*}{ Vision } & $\begin{array}{l}\text { Between } \\
\text { Grouns }\end{array}$ & 9.372 & 4 & 2.343 & 2.964 & $0.019 *$ \\
\hline & Within Groups & 388.126 & 491 & 0.790 & & \\
\hline & Total & 397.498 & 495 & & & \\
\hline \multirow[t]{3}{*}{ Planning } & $\begin{array}{l}\text { Between } \\
\text { Groups }\end{array}$ & 2.654 & 4 & 0.663 & 1.277 & 0.278 \\
\hline & Within Groups & 255.076 & 491 & 0.520 & & \\
\hline & Total & 257.729 & 495 & & & \\
\hline \multirow[t]{3}{*}{ Impacts } & $\begin{array}{l}\text { Between } \\
\text { Groups }\end{array}$ & 1.375 & 4 & 0.344 & 0.363 & 0.835 \\
\hline & Within Groups & 464.265 & 491 & 0.946 & & \\
\hline & Total & 465.640 & 495 & & & \\
\hline \multirow[t]{3}{*}{ Support } & $\begin{array}{l}\text { Between } \\
\text { Groups }\end{array}$ & 17.204 & 4 & 4.301 & 3.991 & $0.003^{* *}$ \\
\hline & Within Groups & 529.116 & 491 & 1.078 & & \\
\hline & Total & 546.320 & 495 & & & \\
\hline
\end{tabular}

Follow-up pairwise comparisons of the interaction effects are further examined using ANOVA, and results are presented in Tables 16 and 17. In terms of perceptions of trust, nonprofit organizations agreed significantly more $(p<.01)$ that indicators of trust exist in their community $(M=4.10, S D=0.58)$ than residents $(M=3.73, S D=0.89)$ even at the more 
conservative Bonferroni adjusted level $(p<0.05)$ and residents agreed significantly more $(M=$ 3.73, $S D=0.89)$ than non-tourism business owners or non-tourism related employment $(M=$ 4.00, $S D=0.74)$.

In terms of a vision, non-profit organizations agreed that indicators of a common vision exist in their community marginally significantly $(p=0.058)$ more $(M=3.60, S D=0.78)$ than government official or local board, commission, or authority $(M=3.20, S D=0.88)$, non-profit organizations agreed significantly more $(M=3.60, S D=0.78)$ than residents $(M=3.26, S D=$ 0.91), non -tourism business owner or non-tourism related employment agreed marginally significantly $(p=0.098)$ more $(M=3.53, S D=0.78)$ than government official or local board, commission, or authority $(M=3.20, S D=0.88)$, and non-tourism business owners or nontourism related employment agreed significantly more $(M=3.53, S D=0.86)$ than residents $(M=$ 3.26, $S D=0.91)$.

In terms of planning, non-profit organizations agreed with the importance of planning significantly more $(M=4.62, S D=0.58)$ than residents $(M=4.39, S D=0.77)$. In terms of support for tourism development, non-profit organizations agreed significantly more $(M=3.74$, $S D=0.73)$ than non-tourism business owners or non-tourism related employment $(M=3.23, S D$ =1.06) even at the more conservative Bonferroni adjusted level, non-profit organizations agreed significantly more $(M=3.74, S D=0.73)$ than residents $(M=3.30, S D=1.12)$ even at the more conservative Bonferroni adjusted level, and tourism business owners or employed in tourism agreed significantly more $(M=3.71, S D=0.89)$ than non-tourism business owners or nontourism related employment $(M=3.23, S D=1.06)$ even at the more conservative Bonferroni adjusted level. 
Table 16 Pairwise Comparisons of Social Capital, Attitudes toward Tourism, and Support for Tourism Development

\begin{tabular}{|c|c|c|c|c|c|c|c|c|}
\hline & & & \multirow{2}{*}{$\begin{array}{c}\text { Mean } \\
\text { Differ } \\
\text { ence } \\
(\mathrm{I}-\mathrm{J})\end{array}$} & \multirow{2}{*}{$\begin{array}{l}\text { Std. } \\
\text { Error }\end{array}$} & \multirow{2}{*}{ Sig $^{1}$. } & \multirow{2}{*}{$\mathrm{Sig}^{2}$. } & \multicolumn{2}{|c|}{$\begin{array}{l}\text { 95\% Confidence } \\
\text { Interval }\end{array}$} \\
\hline & & & & & & & Lower & Upper \\
\hline \multirow{20}{*}{$\begin{array}{l}\text { government } \\
\text { official or local } \\
\text { authority }\end{array}$} & \multirow[t]{5}{*}{ non-profit } & trust & -0.23 & 0.19 & 0.220 & 1.000 & -0.62 & 0.14 \\
\hline & & vision & $-0.40^{*}$ & 0.21 & $0.058^{*}$ & 0.576 & -0.81 & 0.01 \\
\hline & & planning & -0.12 & 0.17 & 0.472 & 1.000 & -0.45 & 0.21 \\
\hline & & impacts & 0.08 & 0.22 & 0.717 & 1.000 & -0.36 & 0.53 \\
\hline & & support & -0.29 & 0.24 & 0.224 & 1.000 & -0.78 & 0.18 \\
\hline & \multirow{5}{*}{$\begin{array}{l}\text { tourism } \\
\text { business } \\
\text { owner or } \\
\text { employed in } \\
\text { tourism }\end{array}$} & trust & -0.01 & 0.18 & 0.944 & 1.000 & -0.38 & 0.35 \\
\hline & & vision & -0.27 & 0.20 & 0.182 & 1.000 & -0.67 & 0.12 \\
\hline & & planning & -0.02 & 0.16 & 0.887 & 1.000 & -0.34 & 0.30 \\
\hline & & impacts & 0.10 & 0.22 & 0.637 & 1.000 & -0.33 & 0.54 \\
\hline & & support & -0.26 & 0.23 & 0.267 & 1.000 & -0.73 & 0.20 \\
\hline & \multirow{5}{*}{$\begin{array}{l}\text { non -tourism } \\
\text { business } \\
\text { owner or non- } \\
\text { tourism } \\
\text { related } \\
\text { employment }\end{array}$} & trust & -0.13 & 0.18 & 0.461 & 1.000 & -0.49 & 0.22 \\
\hline & & vision & $-0.32^{*}$ & 0.19 & $0.098^{*}$ & 0.975 & -0.70 & 0.05 \\
\hline & & planning & 0.04 & 0.15 & 0.774 & 1.000 & -0.26 & 0.35 \\
\hline & & impacts & 0.21 & 0.21 & 0.326 & 1.000 & -0.20 & 0.63 \\
\hline & & support & 0.21 & 0.22 & 0.347 & 1.000 & -0.23 & 0.66 \\
\hline & \multirow[t]{5}{*}{ resident } & trust & 0.12 & 0.16 & 0.440 & 1.000 & -0.19 & 0.45 \\
\hline & & vision & -0.06 & 0.17 & 0.725 & 1.000 & -0.41 & 0.28 \\
\hline & & planning & 0.10 & 0.14 & 0.491 & 1.000 & -0.18 & 0.38 \\
\hline & & impacts & 0.16 & 0.19 & 0.393 & 1.000 & -0.21 & 0.55 \\
\hline & & support & 0.13 & 0.20 & 0.517 & 1.000 & -0.27 & 0.54 \\
\hline \multirow[t]{10}{*}{ non-profit } & tourism & trust & 0.22 & 0.15 & 0.141 & 1.000 & -0.07 & 0.52 \\
\hline & \multirow{4}{*}{$\begin{array}{l}\text { business } \\
\text { owner or } \\
\text { employed in } \\
\text { tourism }\end{array}$} & vision & 0.12 & 0.16 & 0.441 & 1.000 & -0.19 & 0.45 \\
\hline & & planning & 0.09 & 0.13 & 0.459 & 1.000 & -0.16 & 0.36 \\
\hline & & impacts & 0.02 & 0.18 & 0.904 & 1.000 & -0.33 & 0.37 \\
\hline & & support & 0.03 & 0.19 & 0.860 & 1.000 & -0.34 & 0.41 \\
\hline & non-tourism & trust & 0.10 & 0.14 & 0.462 & 1.000 & -0.17 & 0.38 \\
\hline & business & vision & 0.075 & 0.15 & 0.620 & 1.000 & -0.22 & 0.37 \\
\hline & owner or non- & planning & 0.16 & 0.12 & 0.180 & 1.000 & -0.07 & 0.41 \\
\hline & tourism & impacts & 0.12 & 0.16 & 0.453 & 1.000 & -0.20 & 0.45 \\
\hline & $\begin{array}{l}\text { related } \\
\text { employment }\end{array}$ & support & $0.51^{*}$ & 0.18 & $0.005^{* * *}$ & $0.046^{* *}$ & 0.15 & 0.86 \\
\hline
\end{tabular}


Table 16 (continued)

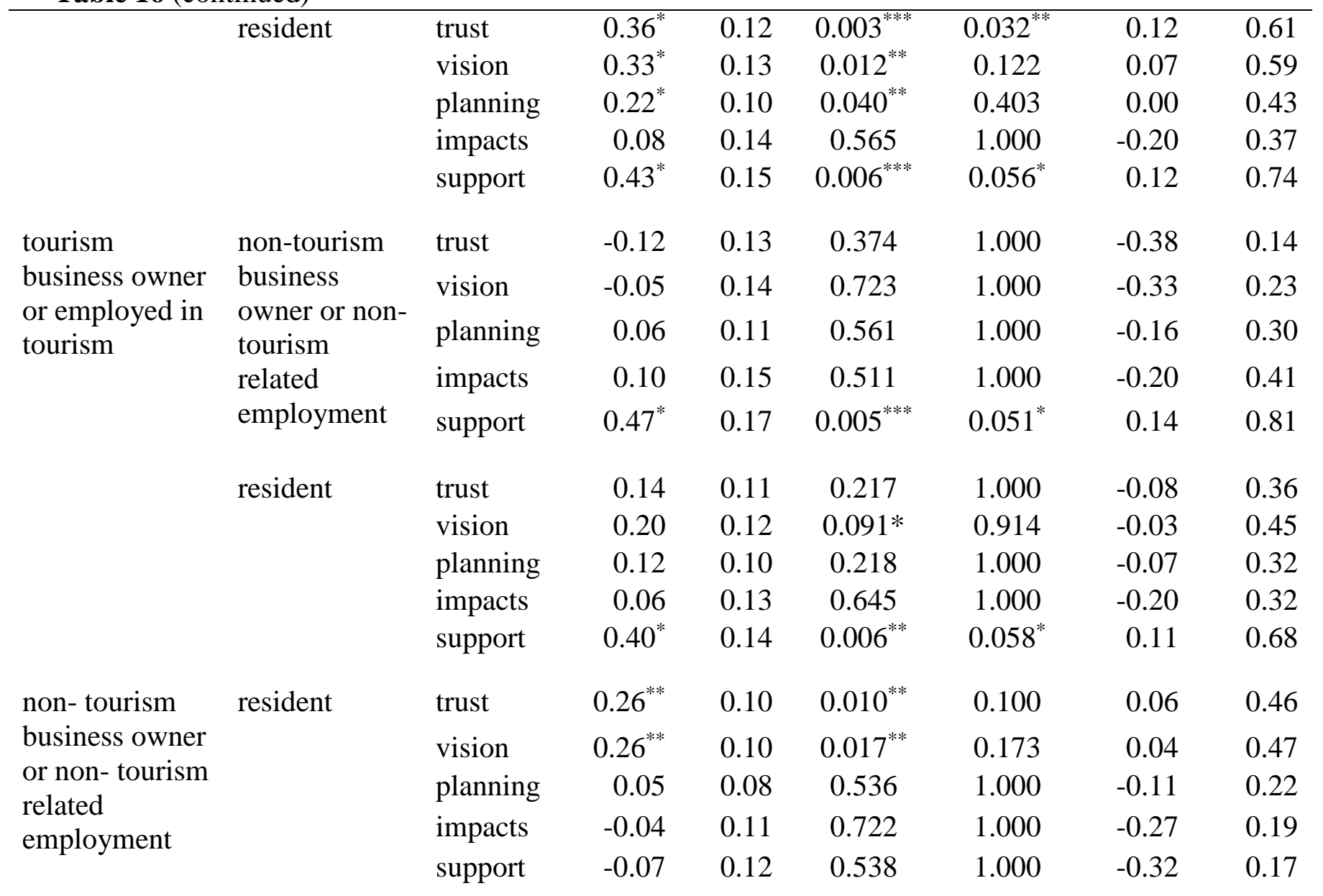

Sig ${ }^{1}$. Refers to $p$ values obtained using the Fishers Least Significant Difference (LSD) test; Sig $^{2}$.

Refers to $p$ values corrected using the Bonferroni test.

${ }^{*} p<0.1,{ }^{* *} p<0.05,{ }^{* * *} p<0.01,{ }^{* * * *} p<0.001$

Table 17 Factor Means According to Role in Community

\begin{tabular}{llcc}
\hline \multicolumn{1}{c}{ Factor } & \multicolumn{1}{c}{ Role } & Mean & SD \\
\hline Trust & $\begin{array}{l}\text { non-profit } \\
\text { non-tourism business owner } \\
\text { or non-tourism related } \\
\text { employment }\end{array}$ & $\mathbf{4 . 1 0}$ & 0.58 \\
& $\begin{array}{l}\text { government official or local } \\
\text { authority }\end{array}$ & 3.86 & 0.74 \\
& $\begin{array}{l}\text { tourism business owner or } \\
\text { employed in tourism }\end{array}$ & 3.87 & 0.92 \\
& & 3.73 & 0.89
\end{tabular}


Table 17 (continued).

\begin{tabular}{|c|c|c|c|}
\hline \multirow{5}{*}{ Vision } & non-profit & 3.60 & 0.78 \\
\hline & $\begin{array}{l}\text { non-tourism business owner } \\
\text { or non-tourism related } \\
\text { employment }\end{array}$ & 3.52 & 0.86 \\
\hline & $\begin{array}{l}\text { tourism business owner or } \\
\text { employed in tourism }\end{array}$ & 3.47 & 0.90 \\
\hline & resident & 3.26 & 0.91 \\
\hline & $\begin{array}{l}\text { government official or local } \\
\text { authority }\end{array}$ & 3.20 & 0.87 \\
\hline \multirow[t]{5}{*}{ Planning } & non-profit & 4.62 & 0.57 \\
\hline & $\begin{array}{l}\text { tourism business owner or } \\
\text { employed in tourism }\end{array}$ & 4.52 & 0.63 \\
\hline & $\begin{array}{l}\text { government official or local } \\
\text { authority }\end{array}$ & 4.50 & 0.66 \\
\hline & $\begin{array}{l}\text { non-tourism business owner } \\
\text { or non-tourism related } \\
\text { employment }\end{array}$ & 4.45 & 0.71 \\
\hline & resident & 4.39 & 0.77 \\
\hline \multirow[t]{5}{*}{ Impacts } & $\begin{array}{l}\text { government official or local } \\
\text { authority }\end{array}$ & 3.07 & 0.82 \\
\hline & non-profit & 2.99 & 0.84 \\
\hline & $\begin{array}{l}\text { tourism business owner or } \\
\text { employed in tourism }\end{array}$ & 2.96 & 1.06 \\
\hline & resident & 2.90 & 1.00 \\
\hline & $\begin{array}{l}\text { non-tourism business owner } \\
\text { or non-tourism related } \\
\text { employment }\end{array}$ & 2.86 & 0.91 \\
\hline \multirow[t]{5}{*}{ Support } & non-profit & 3.74 & 0.72 \\
\hline & $\begin{array}{l}\text { tourism business owner or } \\
\text { employed in tourism }\end{array}$ & 3.70 & 0.89 \\
\hline & $\begin{array}{l}\text { government official or local } \\
\text { authority }\end{array}$ & 3.44 & 0.90 \\
\hline & resident & 3.30 & 1.12 \\
\hline & $\begin{array}{l}\text { non-tourism business owner } \\
\text { or non-tourism related } \\
\text { employment }\end{array}$ & 3.22 & 1.05 \\
\hline
\end{tabular}




\subsection{Discussion}

This study makes an important contribution to the literature on resident attitudes toward tourism by identifying that in addition to the direct effect of the social and environmental impacts of tourism and long-term planning on support for tourism, the indirect effect of social capital is an important factor in understanding resident support for tourism development. This study confirms the findings of other studies that concern for the potential environmental and social impacts of tourism have a direct positive effect on support for additional tourism development (Purdue, Long, \& Allen, 1990; Nunkoo \& Gursoy, 2012; Choi \& Murray, 2010) In addition, this study found that the effect of the social and environmental impacts of tourism on support for tourism was stronger for short term residents than for long term residents consistent with the findings of Vesey and Dimanche (2000), however, contradicting the findings of McCool \& Martin (1994), Um and Crompton (1987) and Williams et al. (1995). The effect of social and environmental impacts of tourism on support for tourism was also stronger for male residents than for female residents.

Interestingly, when examining whether differences in perceived social and environmental impacts of tourism exist according to role in the community, this study found homogeneous attitudes toward the potential social and environmental impacts of tourism between government official or local authority, non-profits, tourism business owners or residents employed in tourism, non-tourism business owners or residents with non-tourism related employment and residents contradicting the findings of previous studies by Lankford (1994) and Byrd et al., (2009) that differences in perceptions of impacts exist according to role, stake, or power in the community. 
However, this study did identify that "stake" or "power" has a significant effect on support for tourism. The findings are consistent with the findings of Deng et al. (2016) and Pizam (1978), that tourism-related residents support tourism more than non-tourism related residents which supports the social exchange theory (Gursoy \& Rutherford) and has been confirmed in previous studies that residents with greater economic dependency on tourism and personal benefit from tourism are more likely to have positive attitudes toward tourism (McGehee \& Andereck, 2004; Milman \& Pizam, 1988; Murphy, 2001; Knollenberg, 2011; Um \& Crompton, 1987; Wang \& Pfister, 2008). In addition, this study identified a higher level of support for tourism among residents involved in non-profit organizations than residents or non-tourism related residents.

In regard to planning for tourism development, this study found that long-term planning is significantly related to support for tourism confirming the findings of previous studies (Choi and Murray, 2010; Oviedo-Garcia, Castellanos-Verdugo, \& Martin-Ruiz, 2008). In addition, consistent with the finding of Oviedo-Garcia, Castellanos-Verdugo, and Martin-Ruiz (2008), this study revealed some differences in attitudes toward planning specifically related to role in the community with non-profit organizations having a significantly higher perception of the importance of long-term planning and protecting community values than residents.

This study found an indirect effect of social capital on support for tourism and consistent with the findings of Park, Nunkoo, and Yoon (2015). This study further confirms that if tourism policies aimed at fostering positive attitudes among rural communities are to be fully effective, planners should pay attention to the level of social capital present among local residents (Park, Nunkoo, \& Yoon, 2015). Specifically, this study established that a common vision and involvement in local organizations and informal social groups are key components of social 
capital that are positively related to the protection of community values and long-term planning and managed growth which have a direct effect on resident support for tourism development. This is consistent with the findings of Wang and Pfister (2008) that that those who are active in community organizations perceive more benefits from increasing tourism opportunities that those who are not active.

In addition, social capital (trust and vision) was perceived to be stronger in the community among residents participating in non-profit organizations and non-tourism related business owners and those employed in non-tourism related jobs and stronger among residents than government officials. However, while a study by McGehee et al. (2010) found that perceived social capital overall within the region was higher among people who lived longer in the region, this study found no significant difference in perceived social capital according to length of residency.

Contrary to the findings of Andereck and Vogt (2000), Johnson, Snepenger and Akis (1994) and Long, Perdue, and Allen (1990), the level of tourism development in the communities had no significant effect on the relationship between social capital, attitudes toward tourism, and support for tourism. Thus, the effect of a common vision and participation in local organizations and informal social groups on long-term planning, protection of community values, growth management, the social and environmental impacts of tourism, and support for tourism development was shared equally among communities regardless of the level of tourism development.

Thus, hypothesis 1 was supported: resident attitudes toward tourism had a direct effect on support for tourism development; hypothesis 2 was partially supported: social capital did not have a direct effect on resident attitudes toward tourism but did have an indirect effect on 
support for tourism development; hypothesis 3 was not supported: the relationship between social capital, attitudes toward tourism, and support for tourism development did not vary among communities in Tucker County according to the level of tourism development; hypothesis 4 was partially supported: the relationship between attitudes toward tourism and support for tourism development did vary in Tucker County according to length of residency but the relationship between social capital, attitudes toward tourism and support for tourism did not vary according to length of residency; hypothesis 5 was partially supported: the relationship between attitudes toward tourism and support for tourism development did vary in Tucker County according to gender but the relationship between social capital, attitudes toward tourism and support for tourism did not vary according to gender; and hypothesis 6 was supported: the level of social capital, attitudes toward tourism, and support for tourism development did differ in Tucker County according to role in the community.

\subsection{Conclusion}

This study makes an important contribution by identifying that establishing a common vision and participation in community organizations can be key factors in predicting support for tourism development. According to Lankford (2001) tourism impact research is (or should be) designed to provide planners a database with which to develop a planning process aimed at addressing local concerns and issues. Specifically, the data from a community environmental scan (via a survey or series of meetings) become the starting point in developing a citizen involvement process (which may take many years) to discuss impacts, to suggest mitigating strategies, and to decide on the scope and density of tourism developments. Second, using appropriate statistical procedures, the planner can identify which groups of people are more concerned or opposed to tourism development within the 
community. This analysis assists the planner in developing a network of concerned citizens and enhances our ability to be sensitive to variations in the level and content of development to reflect local concerns.

Social capital has been viewed as a prerequisite for sustainable tourism and community development (Bowles \& Gintis, 2002; Macbeth, Carson, \& Northcote, 2004). Norms can be reinforced through a variety of processes: forming groups, collaborating within and among groups, developing a common view of a shared future, forming or reinforcing collective identity, and engaging in collective action (Flora et al., 2016). Grootaert (1998) identified that collective decision making depends heavily on the conflict management capabilities of a community that emerge from all three categories of social capital: trust, reciprocity, and cooperation. In tourism, the most successful destinations have found ways to engage in collective decision-making about the goals of the community and how they can be met through the development of a cohesive tourism product (McGehee et. al, 2010).

While this study confirms the finding of other studies that long-term planning and protection of community values are essential for sustainable rural tourism development, this study revealed the need to consider a common vision and participation in local organizations and informal social groups in order to secure resident support for tourism development. Incorporating residents involved in local organizations and informal social groups in the tourism planning process can help in establishing a common vision for tourism and create a tourism development plan that protects community values and includes mechanisms to manage growth and maintain the special qualities of rural destinations that create a high quality of life for local residents and attract visitors. Meetings organized through these social groups and organizations can become the starting point in developing what Lankford 
(2001) suggests for a citizen involvement process to discuss impacts, to suggest mitigating strategies, and to decide on the scope and density of tourism developments. A qualitative analysis of participation in community organizations (see Appendix A) revealed that residents participated in a variety of community organizations with the highest participation in civic organizations. In addition, non-profit organizations had a significantly higher perception of the importance of long-term planning and protecting community values than residents thus they should be engaged as a key stakeholder group in tourism planning initiatives. Short term residents and male residents were more concerned with the potential social and environmental impacts of tourism, which had a stronger effect on their support for tourism and thus extra consideration should be made toward managing the impacts of tourism especially for these residents in the tourism planning process. In addition, support for tourism was weaker among non-tourism related residents and residents than tourism related residents and those participating in non-profit organizations. Therefore, initiatives to generate support for tourism should be targeted toward residents, non-tourism related business owners and those employed in non-tourism related jobs, highlighting how tourism may benefit them since these residents may perceive less benefits from tourism development, and thus are more likely to withdraw their support.

Establishing a common vision that ensures protection of community values as tourism is developed should be a key component of the planning process. When asked if there is a common vision among communities for tourism in Tucker County just $26.3 \%$ agreed or strongly agreed, only 33.5\% agreed or strongly agreed that there is a common vision in their community. When asked if it is important that community values are protected when tourism is developed $65.1 \%$ strongly agreed. Appendix B presents the results of a qualitative assessment of 
community values which revealed the importance of paying special concern in the planning process to the impact tourism can have on rural community values including care-empathy-love for others, safety, small town-rural living, faith, family, honesty, cooperation and collaboration, trust, friendliness, jobs-work-economy, natural beauty, work ethic, respect, support community, togetherness, care for environment/way of life, morals, community growth, peace and quiet, and maintaining authenticity.

While long-term planning is a key component of community tourism that can both mitigate the negative impacts of tourism and reinforce the positive impacts (Choi \& Murray, 2010); social capital, however, can act as an impediment in tourism development if it is not well managed. Just 34.1\% agreed or strongly agreed that there are strong social networks between communities in Tucker County. In addition, only 31.7\% strongly agreed that they feel accepted as a valued resident of their community and just $19.5 \%$ strongly agreed that different opinions are valued in my community. When asked if individuals and organizations in their community cooperate to achieve collective goals just $18.6 \%$ strongly agreed. Given this, establishing a common vision that ensures protection of community values may initially require strengthening of social capital (networks, acceptance, and cooperation) in Tucker County.

While residents support tourism development as an economic opportunity there was some concern about the type of tourism to be developed. Only 36.3\% agreed or strongly agreed that Tucker County should pursue large-scale entertainment style tourism development that will attract large numbers of visitors. When asked about tourism development opportunities the highest ranked as very needed or high priority included nature tourism, unique local shopping, local restaurants, festivals/events, and accommodations. Growth management mechanisms should be enacted to ensure that tourism is developed in a way that complements the natural 
beauty of the destination and does not detract from it as Stanley Plog (2001) noted "destinations move across a spectrum of development far too inexorably toward the potential seeds of their own destruction, as they allow themselves to become more commercialized and lose their qualities which originally attracted tourists”.

Additional open-ended questions revealed the challenges of transitioning from an economy driven by extractive industries to an economy with tourism as a vital component. This destination is at the early stages of Butler's (1980) Tourism Lifecycle model. At these early stages of tourism development, destinations face considerable challenges in balancing the economic impact of tourism with the preservation of the rural landscape and traditional ways of life while managing the "irritations" (Doxey, 1975) which can stem from the impact between residents and outsiders at any given tourist destination.

When asked to describe, “What does tourism mean to you?” it was clear that residents have mixed opinions about tourism as an economic development strategy. The results are presented in Appendix C with positive comments related to economic development (80), sharing their community with outsiders (76), and jobs (65) while negative comments were related to problems (43), low paying - seasonal jobs (27), and nothing/not needed (25). When asked to describe "How can tourism benefit you personally?" responses were mixed including no benefit (79), jobs (60), more local businesses (32), more activities for residents and friends and family (31), and improving the quality of life (28).

Since the early 1900's it has been recognized that tourism development, if not well planned and regulated, may generate unintended environmental and social/cultural problems. Nevertheless, developing tourism in rural areas has been regarded as an effective means for rural economic diversification and promotion since the 1970s (Gartner, 2004). This is particularly true 
for those communities that have traditionally depended on extractive economic activities such as mining and logging, since these industries have declined precipitously in the latter part of the 20th century. West Virginia is the second most rural state in the U.S according to the US Census Bureau (2014). As the economic impact of extractive industries continues to decline, the state's rural communities increasingly look to tourism to help support their economies, however, as the Organization for Economic Cooperation and Development (OECD, 1994) points out, understanding and exploiting tourism for rural communities while trying to maintain a traditional lifestyle is a difficult process.

In order to maximize the positive impacts while minimizing the negative impacts of tourism development on a destination, it is necessary to understand attitudes held by local residents and other stakeholders toward tourism. Also, it is important to engage and empower local residents in tourism planning and development. Participative tourism planning has been promoted by scholars as a way to avoid the negative impacts of tourism and offset some unintended impacts of tourism development such as anger, apathy or mistrust of tourists by locals (Gursoy, Jurowski \& Uysal, 2002). This study makes an important contribution to the existing body of literature on resident attitudes toward tourism and support for tourism by revealing the need to consider a common vision and participation in local organizations and informal social groups in addition to long-term planning, protection of community values, growth management, and the social and environmental impacts of tourism in order to secure resident support for tourism development.

In 2016, the Tucker County, WV CDA adopted four tenets - Protect, Connect, Enhance, and Promote the Culture of Tucker County - and outlined its goals, objectives, and strategies in a performance agenda to guide the CDA's efforts as it works to achieve its vision of successfully 
implementing a community-led cultural tourism plan. It is the authors hope that the results of this study can help to guide the destination toward its goal to adopt a cultural tourism vision and make informed, community-based decisions with input and participation from community stakeholders and residents in an attempt to lead tourism growth, while preserving the County's culture, heritage, and authenticity.

\subsection{Limitations}

As with many other tourism studies, this study is not without limitations. First, although a mailed questionnaire survey was used to target each household in the County, there is no control of who would fill the questionnaire. This may create possible survey response biases. Second, this study provided insight into the relationship between social capital, attitudes toward tourism, and support for tourism in a rural destination. However, the results may be specific to the County and may not be generalized to other rural destinations. Further research is needed to better understand to what extent social capital, resident attitudes toward tourism, and support for tourism vary according to demographic variables. More research is required to better understand destination management practices and challenges to sustainably managing and implementing the challenges and opportunities identified in this study. Sharpley (2000) notes that while the current body of research on resident attitudes and perceptions toward tourism has undoubtedly contributed to a wider understanding and knowledge of the phenomenon there is arguably a need to adopt a more multi-dimensional approach to residents' perceptions from the perspective of both residents themselves and their interactions with tourists. While this study provided a more multi-dimensional approach by including social capital in analysis of factors predicting support for tourism development, future studies should 
incorporate the perspective of visitors and residents' interaction with visitors to further develop a more multi-dimensional approach.

\subsection{References}

Andereck, K. L., Valentine, K. M., Knopf, R. C., \& Vogt, C. A. (2005). Residents’ perceptions of community tourism impacts. Annals of tourism research, 32(4), 1056-1076.

Andereck, K. L., \& Vogt, C. A. (2000). The relationship between residents' attitudes toward tourism and tourism development options. Journal of Travel research, 39(1), 27-36.

Andriotis, K., \& Vaughan. (2003). Urban residents' attitudes toward tourism development: the case of Crete. Journal of Travel Research, 42(2).

Ap, J. (1992). Residents’ perceptions on tourism impacts. Annals of Tourism Research, 19(4).

Belisle, F.J. and D.R. Hoy (1980). The perceived impact of tourism by residents: A case study in Santa Marta, Colombia. Annals of Tourism Research, 12(1), 83-101.

Bender, M., Deng, J., Selin, S., Arbogast, D., \& Hobbs, R.A. (2008). Local residents' attitudes toward potential tourism development: A case of Ansted, WV. Proceedings of the 2008 Northeastern Recreation Research Symposium. 85-94.

Bernard, h. R. (2006). Research methods in anthropology. Lanham, MD: AltaMira.

Bestard, B., \& Nadal, R. (2007). Attitudes toward tourism and tourism congestion. Région et Développment, 25.

Bohm, D., and Nichol, L. (1996). On Dialogue. London: Routledge Press.

Borgatti, S.P., Everett, M.G. and Freeman, L.C. (2002). Ucinet for Windows: Software for Social Network Analysis. Harvard, MA: Analytic Technologies.

Bowles, S., \& Gintis, H. (2002). Social capital and community governance. The Economic Journal, 112(483), 419-436.

Butler, R. W. (1980). The concept of a tourist area cycle of evolution: Implications for management of resources. Canadian Geographer, 24, 5-12. 
Byrd, E. T. (1997). Barriers to rural tourism: A comparison of the perceptions of the host community, local business owners, and tourists. Unpublished master's thesis, North Carolina State University, Raleigh, NC.

Byrd, E. T. (2003). An analysis of variables that influence stakeholder participation and support for sustainable tourism development in rural North Carolina. Unpublished dissertation, North Carolina State University, Raleigh, NC.

Byrd, E. T. \& Bosley, H. E. (2004). Stakeholder Perceptions of Tourism Impacts in Eastern North Carolina. Proceedings of the 2004 Travel and Tourism Research Association Annual Conference.

Byrd, E. T., Bosley, H. E., \& Dronberger, M. G. (2009). Comparisons of stakeholder perceptions of tourism impacts in rural eastern North Carolina. Tourism Management, 30(5), 693-703.

Cavus, S., \& Tanrisevdi, A. (2003). Residents' attitudes toward tourism development: A case study in Kusadasi, Turkey. Tourism Analysis, 7(3-4), 259-269.

Choi, H. C., \& Murray, I. (2010). Resident attitudes toward sustainable community tourism. Journal of Sustainable Tourism, 18(4), 575-594.

Cohen, E. (1972). Toward a sociology of international tourism. Social research, 164-182.

Coleman, J. S. (1988). Social capital in the creation of human capital. American journal of sociology, S95-S120.

Comrey, A. L., \& Lee, H. B. (2013). A first course in factor analysis. $2^{\text {nd }}$ ed. New York. Psychology Press.

Creswell, J. W., \& Clark, V. L. P. (2007). Designing and conducting mixed methods research. Thousand Oaks, CA: Sage.

Dale, A., \& Onyx, J. (2005). Social capital and sustainable community development: a dynamic balance. Vancouver, BC: UBC Press.

Dale, A. (2001). At the edge: Sustainable development in the 21st Century. Vancouver: UBC Press.

Deng, J., \& Bender, M.Y. (2008). Visitors' perceptions of tourism development in West Virginia. In L. Cherie and V. Christine (comps), Proceedings of the 2007 northeastern recreation 
research symposium (pp.181-188). Newtown Square, PA: U.S. Department of Agriculture, Forest Service, Northern Research Station.

Deng, J., McGill, D., Arbogast, D., \& Maumbe, K. (2016). Stakeholders' Perceptions of Tourism Development in Appalachian Forest Heritage Area. Tourism Review International, 20(4), 235-253.

Dillman, D. A., Smyth, J. D., \& Christian, L. M. (2014). Internet, phone, mail, and mixed-mode surveys: the tailored design method. John Wiley \& Sons.

Dougherty, M. (2014). Tucker County Comprehensive Plan.

Doxey, G.V. (1975). A causation theory of visitor-resident irritants: Methodology and research inferences. Travel and Tourism Research Association Sixth Annual Conference Proceedings (pp. 195-198). San Diego, CA: Travel and Tourism Research Association.

Etzioni, A. (2000). Creating Good Communities and Good Societies. Contemporary Sociology 29(1). 188-95.

Falk, I., \& Kilpatrick, S. (2000). What is social capital? A study of interaction in a rural community. Sociologia Ruralis, 40(1), 87-110.

Fick, G. R., \& Ritchie, J. B. (1991). Measuring service quality in the travel and tourism industry. Journal of Travel Research, 30(2), 2-9.

Flora, C.B., Flora, J.L., \& Gasteyer, S.P. (2016). Rural communities: Legacy and change. Boulder, CO: Westview Press.

Flora, C. B. (2004). Community Dynamics and Social Capital. In Agroecosystems Analysis, edited by D. Rickerl and C. Francis. Madison, WI: American Society of Agronomy, Inc., Crop Science Society of America, Inc., Soil Science Society of America, Inc., pp. 93-107.

Fornell, C., \& Larcker, D. F. (1981). Structural equation models with unobservable variables and measurement error: Algebra and statistics. Journal of Marketing Research, 18(3), 382-388.

Franch, M., \& Martini, U. (2002). Destinations and destination management in the Alps: A proposal for a classification scheme in the light of some ongoing experiences. Paper presented at meeting "Territoires et marchés ème colloque de recherche en tourisme de l'Association française des IUP Tourisme, Hôtellerie et Loisirs", Université de Savoie, Site de Chambery (F), 12-14 settembre. 
Gartner, W. (2004). Rural tourism development in the USA. International Journal of Tourism Research, 6(3), 151-164.

George, E.W., Mair, H., \& Reid, D.G. (2009). Rural Tourism Development: Localism and Cultural Change. Ontario: Channel View.

Gray, B. 1999. Theoretical Perspectives on Collaboration over the Last Decade: Looking Back and Looking Forward. Paper presented at the Collaboration Research Workshop, Collaboration Research Group, University of Technology, Sydney.

Grootaert, C., \& Van, B. T. (Eds.). (2002). Role of Social Capital in Development : An Empirical Assessment. West Nyack, NY, USA: Cambridge University Press. Retrieved from http://www.ebrary.com

Grootaert, C. (1998). Social Capital: The Missing Link? In Monitoring Environmental Progress-Expanding the Measure of Wealth. Washington, DC: World Bank.

Gunn, C. A., \& Var, T. (2002). Tourism planning: Basics, concepts, cases. Psychology Press.

Gursoy, D., Jurowski, C., \& Uysal, M. (2002). Resident attitudes: A structural modeling approach. Annals of tourism research, 29(1), 79-105.

Gursoy, D., \& Rutherford, D. G. (2004). Host attitudes toward tourism: An improved structural model. Annals of Tourism Research, 31(3), 495-516.

Hanifan, L. J. (1916). The rural school community center. Annals of the American Academy of political and social science, 67, 130-138.

Harrill, R. (2004). Residents' attitudes toward tourism development: A literature review with implications for tourism planning. Journal of Planning Literature, 18(3), 251-266.

Holden, A. (2010). Exploring stakeholders' perceptions of sustainable tourism development in the Annapurna conservation area: issues and challenge. Tourism and Hospitality Planning \& Development, 7(4), 337-351.

Hollinshead, K., \& Jamal, T.B. (2007). Tourism and "the Third Ear": Further prospects for qualitative inquiry. Tourism Analysis, 12(1-2), 85-129.

Howie, F. (2003). Managing the tourist destination. London: Continuum. 
Hu, L. T., \& Bentler, P. M. (1999). Cutoff criteria for fit indexes in covariance structure analysis: Conventional criteria versus new alternatives. Structural equation modeling: a multidisciplinary journal, 6(1), 1-55.

Jafari J. (1988). Retrospective and prospective views on tourism as a field of study. Paper presented at the 1988 Meeting of the Academy of Leisure Sciences, Indianapolis, Indiana.

Jamal, T. B., \& Getz, D. (1995). Collaboration theory and community tourism planning. Annals of tourism research, 22(1), 186-204.

Jamal, T., \& Jamrozy, U. (2006). Collaborative networks and partnerships for integrated destination management. Tourism management dynamics-trends, management and tools, 164-172.

Johnson, J. D., Snepenger, D. J., \& Akis, S. (1994). Residents' perceptions of tourism development. Annals of Tourism Research, 21(3), 629-642.

Jones, S. (2005). Community-based ecotourism: The significance of social capital. Annals of Tourism Research, 32(2), 303-324.

Kayat, K. (2008). Stakeholders' perspectives toward a community-based rural tourism development. European Journal of Tourism Research, 1(2), 94.

Kimbu, A. N., \& Ngoasong, M. Z. (2013). Centralised decentralisation of tourism development: a network perspective. Annals of Tourism Research, 40, 235-259.

Knack, S., \& Keefer, P. (1997). Does social capital have an economic payoff? A cross-country investigation. The Quarterly journal of economics, 1251-1288.Knollenberg, W. (2011). Stakeholders' attitudes towards sustainable tourism development in coastal communities (Dissertations). Retrieved December 15, 2015 from http://search.proquest.com.www.libproxy.wvu.edu/docview/889068285?pqorigsite $=$ summon

Knollenberg, W. (2011). Stakeholders' attitudes towards sustainable tourism development in coastal communities. Unpublished Master thesis, East Carolina University, Greenville, NC. Retrieved from http://thescholarship.ecu.edu/bitstream/handle/10342/3667/Knollenberg_ecu_0600M_10455. pdf? sequence $=1$ 
Kuvan, Y., \& Akan, P. (2012). Conflict and agreement in stakeholder attitudes: residents’ and hotel managers' views of tourism impacts and forest-related tourism development. Journal of Sustainable Tourism, 20(4), 571-584.

Lane, B. (1994). What is Rural Tourism? Journal of Sustainable Tourism, 2(1-2). 7-21.

Lane, B. (2009). Thirty years of sustainable tourism: Drivers, progress, problems and the future. In S. Gossling, M.C. Hall, \& D.B. Weaver (Eds.), Sustainable tourism futures: Perspectives on systems, restructuring, and innovations (pp. 19-32). New York and London: Routledge.

Lankford, S. V. (2001). A comment concerning" developing and testing a tourism impact scale". Journal of Travel Research, 39(3), 315-316.

Lankford, S. V., \& Howard, D. R. (1994). Developing a tourism impact attitude scale. Annals of tourism research, 21(1), 121-139.

Larsen, L., Harlan, S. L., Bolin, B., Hackett, E. J., Hope, D., Kirby, A., \& Wolf, S. (2004). Bonding and bridging understanding the relationship between social capital and civic action. Journal of Planning Education and Research, 24(1), 64-77.

Lawson, R., Williams, J., Young, T., \& Cossens, J. (1998). A comparison of residents’ attitudes towards tourism in 10 New Zealand destinations. Tourism Management, 19(3), 247-256.

Long, P. T., Perdue, R. R., \& Allen, L. (1990). Rural resident tourism perceptions and attitudes by community level of tourism. Journal of Travel Research, 28(3), 3-9.

Lu, Z. H., Chow, S. M., \& Loken, E. (2016). Bayesian factor analysis as a variable-selection problem: Alternative priors and consequences. Multivariate behavioral research, 51(4), 519539.

Lu, J., \& Nepal, S. K. (2009). Sustainable tourism research: An analysis of papers published in the Journal of Sustainable Tourism. Journal of Sustainable Tourism, 17(1), 5-16.

Macbeth, J., Carson, D., \& Northcote, J. (2004). Social capital, tourism and regional development: SPCC as a basis for innovation and sustainability. Current Issues in Tourism, 7(6), 502-522.

McCool, S. F., \& Martin, S. R. (1994). Community attachment and attitudes toward tourism development. Journal of Travel research, 32(3), 29-34. 
McGehee, N. G., Andereck, K. L., \& Vogt, C. A. (2002). An examination of factors influencing resident attitudes toward tourism in twelve Arizona communities. In Proceedings of the 33rd Annual Travel and Tourism Research Association Conference, Arlington, VA.

McGehee, N. G., \& Andereck, K. L. (2004). Factors predicting rural residents' support of tourism. Journal of Travel Research, 43(2), 131-140.

McGehee, N. G., Lee, S., O'Bannon, T. L., \& Perdue, R. R. (2010). Tourism-related social capital and its relationship with other forms of capital: An exploratory study. Journal of Travel Research, 49(4), 486-500.

McGehee, N. G., Boley, B. B., Hallo, J. C., McGee, J. A., Norman, W., Oh, C. O., \& Goetcheus, C. (2013). Doing sustainability: an application of an inter-disciplinary and mixed-method approach to a regional sustainable tourism project. Journal of Sustainable Tourism, 21(3), 355-375.

Milman, A. \& Pizam, A. (1988). Social impacts of tourism on Central Florida. Annals of Tourism Research, 15 (2), 191-204.

Molina-Azorín, J. F., \& Font, X. (2015). Mixed methods in sustainable tourism research: an analysis of prevalence, designs and application in JOST (2005-2014). Journal of Sustainable Tourism, 1, 1-25.

Murphy, P. (1981). Community attitudes on tourism: A comparative analysis. Tourism Management, 2(2), 189-195.

Murphy, P. E. (1983). Perceptions and attitudes of decision making groups in tourism centers. Journal of Travel Research, 21 (3), 8-12.

Ngoasong, M. Z. (2011). Transcalar networks for policy transfer and implementation: The case of global health policies for malaria and HIV/AIDS in Cameroon. Health Policy and Planning, 26(1), 63-72.

Nunnally, J.C., (1978). Psychometric Theory, $2^{\text {nd }}$ ed. New York. McGraw Hill.

Nunkoo, R., \& Gursoy, D. (2012). Residents' support for tourism: An identity perspective. Annals of Tourism Research, 39(1), 243-268.

Nunkoo, R., \& Ramkissoon, H. (2010). Small island urban tourism: a residents' perspective. Current Issues in Tourism, 13(1), 37-60. 
Nunkoo, R., \& Ramkissoon, H. (2011). Developing a community support model for tourism. Annals of Tourism Research, 38(3), 964-988.

Nunkoo, R., \& Ramkissoon, H. (2012). Structural equation modelling and regression analysis in tourism research. Current Issues in Tourism, 15(8), 777-802.

Okazaki, E. (2008). A community-based tourism model: Its conception and use. Journal of sustainable tourism, 16(5), 511-529.

Onyx, J., \& Bullen, P. (2000). Measuring social capital in five communities. The journal of applied behavioral science, 36(1), 23-42.

Oppermann, M. (2000). Triangulation--a methodological discussion. The International Journal of Tourism Research, 2(2), 141.

Organization for Economic Cooperation and Development (1994). Tourism strategies and rural development. Retrieved from http://www.oecd.org/cfe/tourism/2755218.pdf

Oviedo-Garcia, M. A., Castellanos-Verdugo, M., \& Martin-Ruiz, D. (2008). Gaining residents' support for tourism and planning. International journal of tourism research, 10(2), 95-109.

Özdemir, G., Yilmaz, M., Yalçin, M., \& alvarez, M. D. (2015). Stakeholders’ Perception of Istanbul's Historical Peninsula as a Sustainable Destination. Tourism Planning \& Development, 12(1), 87-98.

Park, D. B., Nunkoo, R., \& Yoon, Y. S. (2015). Rural residents' attitudes to tourism and the moderating effects of social capital. Tourism Geographies, 17(1), 112-133.

Pasape, L., Anderson, W., \& Lindi, G. (2013). Towards sustainable ecotourism through stakeholder collaborations in Tanzania. Journal of Tourism Research \& Hospitality, 2(1).

Perdue, R. R., Long, P. T., \& Allen, L. (1987). Rural resident tourism perceptions and attitudes. Annals of Tourism Research, 14(3), 420-429.

Perdue, R. R., Long, P. T., \& Allen, L. (1990). Resident support for tourism development. Annals of tourism Research, 17(4), 586-599.

Pizam, A. (1978) Tourism impacts: the social costs to the destination community as perceived by its residents. Journal of Travel Research. 16(4), 8-12. 
Plano Clark, V. L. (2005). Cross-disciplinary analysis of the use of mixed methods in physics education research, counseling psychology, and primary care (Ph.D. dissertation). The University of Nebraska-Lincoln, USA.

Plog, S. (2001). Why destination areas rise and fall in popularity. The Cornell Hotel and Restaurant Administration Quarterly 42(3), 13-24.

Pomeranz, E. F., Needham, M. D., \& Kruger, L. E. (2013). Stakeholder perceptions of indicators of tourism use and codes of conduct in a coastal protected area in Alaska. Tourism in Marine Environments, 9(1-2), 95-115.

Portes, A. (1998). Social capital: Its origins and applications in modern sociology. Annual Review of Sociology, 24(1): 1-24.

Presenza, A., Sheehan, L., \& Ritchie, J. B. (2005). Towards a model of the roles and activities of destination management organizations. Journal of Hospitality, Tourism and Leisure Science, 3(1), 1-16.

Putnam, R. D. (2001). Bowling alone. New York, NY: Simon and Schuster.

Putnam, R. D. (1993). The prosperous community: social capital and public life. The American Prospect, (13).

Putnam, R. D., Leonardi, R., \& Nanetti, R. Y. (1994). Making democracy work: Civic traditions in modern Italy. Princeton, NJ: Princeton University Press.

Reid, D. G., Mair, H., \& George, W. (2004). Community tourism planning: A self-assessment instrument. Annals of Tourism Research, 31(3), 623-639.

Ritchie, J. R. B., \& Crouch, G. I. (2003). The competitive destination: A sustainable tourism perspective. Wallingford, UK : CABI Publishing.

Robinson, J. (2004). Squaring the circle? Some thoughts on the idea of sustainable development. Ecological economics, 48(4), 369-384.

Rosenow J, Pulsipher G. 1979. Tourism: the Good, the Bad, the Ugly. Century Three Press: Nebraska. 
Rowley, T (1997) Stakeholder Theory: Where Does it Fit Among Existing Theories of the Firm. Proceedings of the International Association for Business and Society, San Destin, Florida.

Runyan, D. (2017). West Virginia Travel Impacts 2000-2016p. Retrieved from https://wvtourism.com/wp-content/uploads/2018/04/WVImp-1.pdf

Sharpley, R. (2000). Tourism and sustainable development: Exploring the theoretical divide. Journal of Sustainable tourism, 8(1), 1-19.

Sheehan, L. R., \& Ritchie, J. R. B. (2005). Destination stakeholders: Exploring identity and salience. Annals of Tourism Research, 32(3), 711-734.

Sheldon, P. J., \& Var, T. (1984). Resident attitudes to tourism in North Wales. Tourism Management, 5(1), 40-47.

Steenkamp, J. B. E., \& Baumgartner, H. (1998). Assessing measurement invariance in crossnational consumer research. Journal of consumer research, 25(1), 78-90.

Timur, S., \& Getz, D. (2008). A network perspective on managing stakeholders for sustainable urban tourism. International Journal of Contemporary Hospitality Management, 20(4), 445461.

Tomljenovic, R., \& Faulkner, B. (2000). Tourism and older residents in a sunbelt resort. Annals of Tourism Research, 27(1), 93-114.

Um, S., \& Crompton, J. (1987). Measuring resident's attachment levels in a host community. Journal of Travel Research, 26(1), 27e29.

U. S. Census Bureau (n.d.). 2010 Census Urban and Rural Classification and Urban Area Criteria. Retrieved from http://www.census.gov/geo/reference/ua/urban-rural-2010.html

U.S. Census Bureau: State and County QuickFacts. (2014). Data derived from Population Estimates, American Community Survey, Census of Population and Housing, State and County Housing Unit Estimates, County Business Patterns, Nonemployer Statistics, Economic Census, Survey of Business Owners, Building Permits. Retrieved from http://quickfacts.census.gov/qfd/states/54000.html

Vargas-Sánchez, A., Porras-Bueno, N., \& Plaza-Mejía, M. (2011). Explaining residents’ attitudes to tourism: Is a universal model possible? Annals of Tourism Research, 38(2). 
Vesey, C. M., \& Dimanche, F. (2000). Urban residents’ perceptions of tourism and its impacts. Unpublished manuscript, University of New Orleans, LA.

Wall, G., \& Mathieson, A. (2006). Tourism: Change, impacts and opportunities. Harlow: Pearson. Prentice Hall.

Wang, Y., \& Pfister, R.E. (2008). Residents' attitudes toward tourism and perceived personal benefits in a rural community. Journal of Travel Research, 47(1), 84-93.

Walker, P.A., Greiner, R., McDonald, D. and Lyne, V. (1999). The tourism futures simulator: systems thinking approach. Environmental Modelling and Software, 14, 59-67.

Wang, Y., \& Pfister, R.E. (2008). Residents' attitudes toward tourism and perceived personal benefits in a rural community. Journal of Travel Research, 47(1), 84-93.

Weaver, D. (2001). Weaver, D. (2001). Sustainable tourism: Theory and practice. London \& New York: Routledge.

Wheaton, B., Muthen, B., Alwin, D. F., \& Summers, G. F. (1977). Assessing reliability and stability in panel models. Sociological methodology, 8, 84-136.

Williams, D., McDonald, C. D., Riden, C. M., \& Uysal, M. (1995). Community attachment, regional identity, and resident attitude toward tourism development. In Unpublished paper presented at conference on global tourism. New Rules, new strategies, 26th Annual Conference Proceedings of the Travel and Tourism Research Association. Acapulco, Mexico.

Wilson, S., Fesenmaier, D.R., Fesenmaier, J., \& Van Es, J.C. (2001). Factors for Success in Rural Tourism Development. Journal of Travel Research, 40. 132-138.

Woolcock, M. (2002). Social capital in theory and practice: where do we stand. Social capital and economic development: Well-being in developing countries, 18-39.

Woolcock, M., \& Narayan, D. (2000). Social capital: Implications for development theory, research, and policy. The World Bank Research Observer, 15(2), 225-249.

Woolcock, M. (2001). The place of social capital in understanding social and economic outcomes. Canadian journal of policy research, 2(1), 11-17.

Yuksel, F., Bramwell, B., \& Yuksel, A. (1999). Stakeholder interviews and tourism planning at Pamukkale, Turkey. Tourism Management, 20(3), 351-360. 
Zhao, W., Ritchie, J. B., \& Echtner, C. M. (2011). Social capital and tourism entrepreneurship. Annals of Tourism Research, 38(4), 1570-1593. 
Appendix A groups or associations in Tucker County that respondents volunteered with, worked for, or otherwise supported in Tucker County within the past 12 months.

\begin{tabular}{|c|c|c|c|c|c|}
\hline Group & References & Group & References & Group & References \\
\hline events & 33 & civic organizations & & public lands & \\
\hline youth sports & 15 & religious groups & 59 & CVNWR & 14 \\
\hline $\begin{array}{l}\text { Tucker Community } \\
\text { Foundation }\end{array}$ & 15 & VFD & 38 & state parks & 4 \\
\hline $\begin{array}{l}\text { WVU Extension } \\
\text { program }\end{array}$ & 12 & seniors & 32 & national forest & 2 \\
\hline other & 11 & schools & 28 & NYSF & 1 \\
\hline CVB-Chamber & 11 & food programs & 18 & $\begin{array}{l}\text { CV State Park } \\
\text { Foundation }\end{array}$ & 1 \\
\hline health-wellness & 7 & library & 15 & Friends groups & \\
\hline people less fortunate & 4 & womens group & 10 & Friends of 500th & 16 \\
\hline non-profit organizations & & veterans assoc. & 8 & $\begin{array}{l}\text { Friends of } \\
\text { Blackwater }\end{array}$ & 8 \\
\hline Camp Horseshoe & 3 & Lions Club & 7 & Friends of Cheat & 3 \\
\hline humane society & 2 & homeowners assoc. & 7 & $\begin{array}{l}\text { Friends of Cortland } \\
\text { Acres }\end{array}$ & 1 \\
\hline Canaan Valley Institute & 2 & Rotary & 6 & \multicolumn{2}{|c|}{ county and local government } \\
\hline national ski patrol & 1 & animal shelter & 6 & EMS & 9 \\
\hline Rubenstein Center & 1 & $\begin{array}{l}\text { Knights of } \\
\text { Columbus }\end{array}$ & 4 & local government & 8 \\
\hline art & & farmers market & 4 & parks and rec & 5 \\
\hline art spring & 16 & scouts & 3 & $\begin{array}{l}\text { planning } \\
\text { commission }\end{array}$ & 4 \\
\hline student art program & 3 & historical society & 3 & $\begin{array}{l}\text { development } \\
\text { authority }\end{array}$ & 3 \\
\hline community theater & 2 & Masonic Lodge & 2 & law enforcement & 2 \\
\hline Buxton Gallery & 1 & FRN & 2 & TC zoning board & 1 \\
\hline mountain arts district & 1 & $\begin{array}{l}\text { Davis Bad } \\
\text { Buildings }\end{array}$ & 2 & $\begin{array}{l}\text { solid waste } \\
\text { authority }\end{array}$ & 1 \\
\hline Lamplight Gallery & 1 & community center & 1 & local elections & 1 \\
\hline heritage & & community action & 1 & humane society & 1 \\
\hline $\begin{array}{l}\text { Alpine Heritage } \\
\text { Preservation }\end{array}$ & 5 & $\begin{array}{l}\text { Isaac Walton } \\
\text { league }\end{array}$ & 1 & Corrections & 1 \\
\hline trails & & LEPC & 1 & local businesses & \\
\hline Heart of Highlands & 6 & city tree committee & 1 & Timberline & 5 \\
\hline TC Trails & 5 & community garden & 1 & Whitegrass & 4 \\
\hline Allegheny Highlands & 2 & Eagles & 1 & Canaan Valley & 1 \\
\hline Trail Foundation & & & & Resort & \\
\hline Rails to Rrails & 2 & book club & 1 & newspaper & 1 \\
\hline
\end{tabular}


Appendix A (continued)

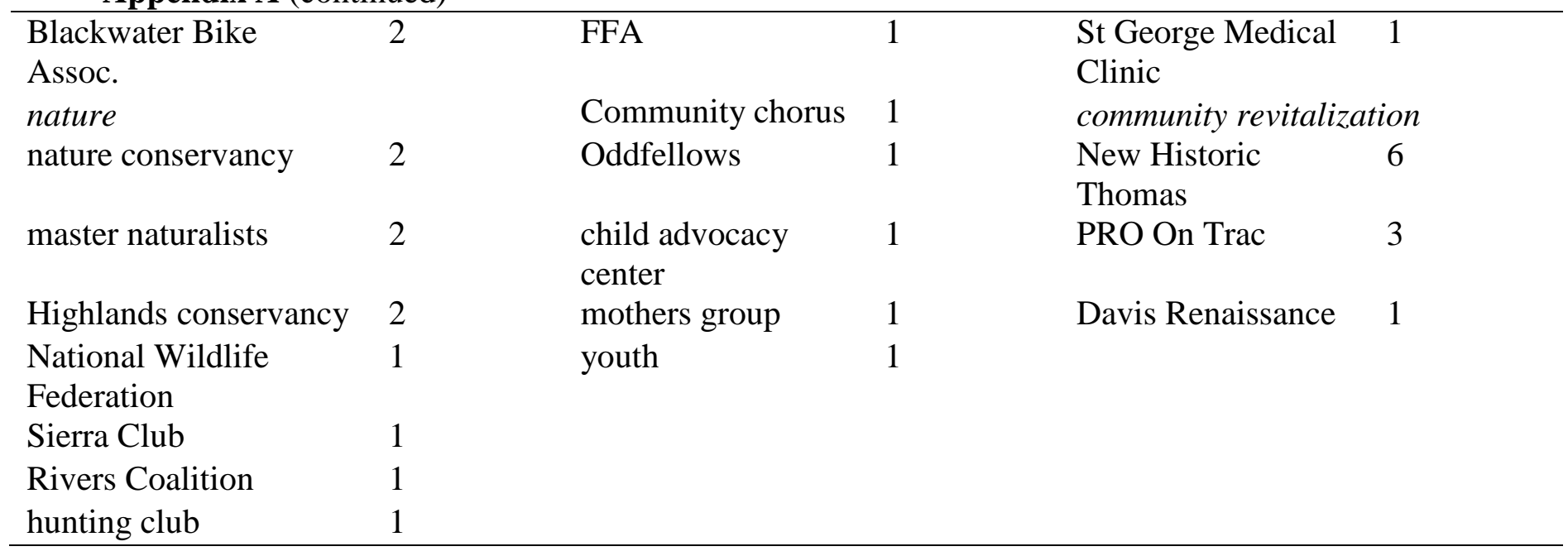


Appendix B: What values do you feel are important in your community?

\begin{tabular}{|c|c|c|c|}
\hline Theme & References & Theme & References \\
\hline people & & community & \\
\hline care-empathy-love for others & 56 & safety & 54 \\
\hline family & 46 & small town-rural living & 54 \\
\hline honesty & 40 & faith & 50 \\
\hline cooperation and collaboration & 32 & jobs-work-economy & 29 \\
\hline trust & 32 & natural beauty & 27 \\
\hline friendliness & 31 & work ethic & 21 \\
\hline respect & 20 & $\begin{array}{l}\text { community growth - } \\
\text { improvement }\end{array}$ & 13 \\
\hline support community & 20 & education & 13 \\
\hline togetherness & 18 & peace and quiet & 12 \\
\hline $\begin{array}{l}\text { care for environment and way } \\
\text { of life }\end{array}$ & 15 & maintaining way of life & 12 \\
\hline morals & 14 & maintaining authenticity & 11 \\
\hline friends & 13 & outdoor recreation & 8 \\
\hline integrity & 10 & supporting the youth & 7 \\
\hline kindness & 7 & patriotism & 7 \\
\hline communication & 4 & strong leadership & 5 \\
\hline proud & 4 & heritage & 4 \\
\hline generous & 2 & $\begin{array}{l}\text { clean environment and } \\
\text { properties }\end{array}$ & 4 \\
\hline law abiding & 2 & professionalism & 4 \\
\hline love & 2 & appreciation of arts & 4 \\
\hline sincerity & 2 & traditions & 3 \\
\hline self-reliant & 2 & affordable living & 5 \\
\hline conservative & 2 & guns & 2 \\
\hline tight knit & 2 & diversity & 2 \\
\hline resilient & 1 & public services & 2 \\
\hline fair & 1 & healthcare & 2 \\
\hline smart & 1 & privacy & 2 \\
\hline independence & 1 & survival & 1 \\
\hline excellence & 1 & money & 1 \\
\hline tolerance & 1 & equal taxation & 1 \\
\hline gratitude & 1 & have fun & 1 \\
\hline equality & 1 & sports & 1 \\
\hline ethical & 1 & events & 1 \\
\hline polite & 1 & welfare and drugs & 1 \\
\hline loyalty & 1 & handicap accessibility & 1 \\
\hline open mind & 1 & volunteerism & 1 \\
\hline
\end{tabular}


Appendix B (continued)

\begin{tabular}{llll}
\hline inclusiveness & 1 & pride in property & 1 \\
ingenuity & 1 & drug free & 1 \\
creativity & 1 & healthy lifestyles & 1 \\
competency & 1 & & \\
commitment & 1 & & \\
\hline
\end{tabular}


Appendix C: What does tourism mean to you?

\begin{tabular}{|c|c|c|c|}
\hline Theme & References & Theme & References \\
\hline Positive & & Negative & \\
\hline economic development & 80 & problems & 43 \\
\hline sharing with outsiders & 76 & $\begin{array}{l}\text { low paying - seasonal } \\
\text { jobs }\end{array}$ & 27 \\
\hline jobs & 65 & nothing/not needed & 25 \\
\hline community development & 29 & seasonal jobs & 3 \\
\hline opportunities & 14 & higher taxes & 1 \\
\hline sustainable development & 10 & & \\
\hline tax revenue & 5 & & \\
\hline outdoor recreation & 4 & & \\
\hline for younger generation & 1 & & \\
\hline support for public services & 1 & & \\
\hline
\end{tabular}


Appendix D: How can tourism benefit you personally?

\begin{tabular}{|c|c|c|c|}
\hline Theme & References & Theme & References \\
\hline Positive & & Negative & \\
\hline jobs & 60 & no benefit & 79 \\
\hline more local businesses & 32 & increase property value & 10 \\
\hline $\begin{array}{l}\text { activities for residents, } \\
\text { friends and family }\end{array}$ & 31 & & \\
\hline improve quality of life & 28 & & \\
\hline economic development & 11 & & \\
\hline income & 23 & & \\
\hline $\begin{array}{l}\text { enjoy sharing with others } \\
\text { and meeting new people }\end{array}$ & 18 & & \\
\hline more cultural diversity & 16 & & \\
\hline community development & 11 & & \\
\hline preserve natural beauty & 10 & & \\
\hline tax revenue for community & 6 & & \\
\hline improve public services & 5 & & \\
\hline community pride & 5 & & \\
\hline opportunities for youth & 3 & & \\
\hline lower taxes for residents & 2 & & \\
\hline
\end{tabular}




\title{
CHAPTER 4
}

\section{Social Design and Transdisciplinary Partnerships for Sustainable Rural Tourism Development}

\begin{abstract}
This paper describes the transdisciplinary, mixed methods, participatory planning, and social design activities developed and implemented by the West Virginia University Rural Tourism Design Team and associated outcomes. Quantitative and qualitative research in initial stages of the study (key informant interviews, resident attitudes toward tourism survey, visitor preferences survey, economic impact analysis) informed social design activities at latter stages (asset mapping, landscape design/visualization of opportunities and sites targeted for development, and cultural identity design) helping the destination take sequential steps toward achieving its goals and objectives. Opportunities and challenges identified through multiple methods were triangulated and pointed to the same conclusions including the need for long term planning and managed growth; protecting community values; underutilized natural, cultural, and historic assets; the opportunity to develop nature-based, cultural, and historical attractions; and the need for a common vision and collective identity. The transdisciplinary approach provided a scaffolding of outputs to the community with citizen control and active involvement throughout the planning and design process. The incorporation of social design provided tangible outcomes including site designs and a cultural identity.
\end{abstract} Keywords: rural tourism, mixed methods, transdisciplinary, sustainable tourism 


\subsection{Introduction}

Many rural communities have the potential to develop tourism into a major industry if they can understand the potential for tourism development; inform and educate the community to create support; secure investments from public and private sources; manage natural, human, and financial resources; and, build an image for their community (Brown, 2002). However, issues such as lack of adequate planning, poor alignment of tourism development with overall community development goals, and limited interest and/or participation by locals have yielded mixed results (Keogh, 1990). There is an increasing understanding that sustainable tourism planning can be most effectively accomplished through a mixed-methods approach drawing from multiple perspectives (Hollinshead \& Jamal, 2007; Lane, 2009; McGehee, Lee, O'Bannon, \& Perdue, 2010). Transdisciplinary partnerships improve upon interdisciplinary experiences by immersing and engaging the breadth of actors simultaneously, and allowing partners to share assets rather than separately provide expertise (Gibbs, 2017). Trust and communication are gained through interactions with faculty members, practitioners, and community partners.

This paper describes a transdisciplinary mixed-method approach and outcomes from planning and design activities developed and implemented by the West Virginia University Rural Tourism Design Team to support the development of a cultural tourism performance agenda for Tucker County, West Virginia Cultural District Authority (CDA). Project phases included key informant interviews, resident attitudes toward tourism survey, visitor preferences survey, community asset inventory and mapping, landscape design/visualization of opportunities and sites targeted for development, economic impact analysis (current and development options), and cultural identity design workshops. 


\subsection{Literature Review}

\subsubsection{Traditional Methods of Sustainable Tourism Planning}

Rural tourism development draws from a breadth of theories, strategies, and activities to successfully engage stakeholders and identify and promote the development of local tourism assets. According to Kuvan and Akan (2012), identifying the perceptions and attitudes of various stakeholders toward the development of tourism in a community should be taken as a first step in tourism planning to ensure trust, cooperation, harmony and mutual benefit for all those involved. Destination leadership or "key informants" are a critical stakeholder group in successfully developing rural destinations because the successful promotion of development and management planning requires more than usually informed, skilled and dedicated leadership (OECD, 1994).

Numerous authors argue that residents supportive of tourism are a key ingredient to providing high quality visitor experiences (Fick \& Ritchie, 1991). Studies on residents attitudes toward tourism have identified that perceived impacts of tourism activity decrease as distance between the individual's home and the tourism sector of the community increases (Belisle \& Hoy, 1980; Sheldon \& Var, 1984); and, that residents with greater economic dependency and more benefit from sociocultural improvements resulting from tourism are more positive toward tourism, which endorses the social exchange theory (Milman \& Pizam, 1988; Murphy, 2001; and Knollenberg, 2011). In addition to the importance of understanding residents' attitudes, understanding the social capital of a community is vital to understanding whether a region is ready to undertake tourism development in a significant way (Macbeth, Carson \& Northcote, 2004; McGehee et al., 2010).

According to Ritchie and Crouch (2003), sustainable tourism planning and development requires developing an understanding of visitors and their perceptions of the destination. 
Tourism market research is essential for destinations to understand the motives, behaviors, interest in the environment, information sources used and demographic characteristics of its visitors in order to segment and target specific groups of travelers who match the visitor experience offered in the destination (Dolnicar \& Leisch, 2008; Hassan, 2000).

Rural communities leveraging tourism assets as an economic development strategy face many challenges and opportunities, including supporting business development that provides an appropriate product mix for visitors, and maintaining and enhancing quality of life factors that both attract visitors and support a vibrant community for residents. Numerous studies have sought to identify the economic potential of tourism activities and methods of quantifying the sector's impact on both large and small economies (Archer \& Fletcher, 1996; Frechtling \& Horvath, 1998; Song, Dwyer, Li, \& Cao, 2012).

\subsubsection{Toward A New Paradigm - Social Design and Transdisciplinary Approaches}

Public Participation Geographic Information Systems (PPGIS) integrates the use of GIS and mapping at local levels to engage and empower community-based resource assessment, planning, and decision making. GIS also serves as a valuable assessment tool given the spatial nature of tourism (McGehee et al., 2013). When integrated with location-based service applications, research has shown that GIS can assist tourists in the discovery or identification of previously unknown destinations and their businesses, recreational opportunities, cultural/historic amenities and government/information centers (Dye \& Shaw, 2007; Poslad et al., 2001). GIS has been used as a tool in sustainable tourism planning to identify the most sustainable development options (Bahaire \& Elliott-White, 1999; Boers \& Cottrell, 2007; Boyd \& Butler, 1996). 
Participatory planning and design includes working with disenfranchised and underserved populations (Hester, 2016, Thering, 2007, Sanoff, 2010) through service-learning (Angotti, Doble, \& Horrigan, 2012; Bose, Horrigan, Doble, \& Shipp, 2014). Service-learning projects seek to reach high levels of Arnstein’s “Ladder of Citizen Participation” (1969) including citizen control, delegated power, and partnership. What characterizes Transdisciplinary Design in education is both the collaboration of specialists in varying fields and the integration of community members who are given equal power and voice in the process. Listening to community partners is critical for generating a product that fits correctly and which will be used by residents. Design grounded in argumentation requires conversation so that participants may understand, agree, and collaborate on effective action. Second-order cybernetics frames design as conversation for learning together, and second-order design creates possibilities for others to have conversations, to learn, and to act (Cybernetics \& Design, 2015). Social Impact Design and Transdisciplinary Design are recent developments in both Design Education and professional design practice, gaining momentum since 2012. For example, An MFA in Transdisciplinary Design is now offered at The New School: Parsons, School of Design Strategies and follows the objectives of using design methods shared with communities to improve their situation, daylight hidden injustices, share narratives, and empower the community for change (Parsons, 2017). However, the emphasis is most often on urban or global problems rather than the issues faced by rural communities in the United States. An exception has been Emily Pilloton’s work in Bertie, North Carolina, that transformed a high school with design methods in 2010 (Pilloton, 2010), and the Auburn Architecture program, Rural Studio in Alabama (About, n.d.). 
According to Molina-Azorín and Font (2016) a mixed methods approach to the study of sustainable tourism can promote societal change, manage social desirability, create more robust data through stakeholder triangulation, and fosters sustainability through interdisciplinary cooperation. Hollinshead and Jamal (2007, p. 90) have suggested that a mix of methods can provide a "fuller field of vision" than the singular lines of inquiry traditionally used. Due to the complexities of a sustainable tourism project, interdisciplinary research has been promoted (Cole, 2014; Gunn, 1987; McGehee et al., 2013; Ritchie, 2006; Tribe, 1997). Employing a full suite of techniques is more effective in engaging greater numbers and more diverse audiences as different audiences respond to different types of enquiry providing for engagement with an array of stakeholders, a core tenant of sustainable tourism (Cole, 2014; McGehee et al., 2013). Triangulation uses multiple distinct methods of both qualitative and quantitative evidence to establish a particular finding which increases confidence in a result by showing that distinct methods and sources point to the same conclusions (Stynes, 1991). The main effect that triangulation can offer is to overcome the weaknesses of any single method (Molina-Azorín \& Font, 2016). A study by Koc and Boz (2014) found that a large proportion of the research papers (70.3\%) published in the top three tourism journals have not employed triangulation, relying instead on only one method of data collection.

\subsubsection{Theoretical Framework}

Similar to McGehee's et al. (2013) approach of identifying a potential tourism centerpiece for the Blue Ridge Heritage Area, our research team utilized a gap analysis as the methodological framework with the goal to enhance the sustainability of the destination in order to help the CDA achieve its objective of making informed, community-based decisions for cultural tourism development. The research design compared visitors' perceptions of the area to 
both the existing tourism infrastructure and resident and key informants' attitudes and opinions of the destination. According to McGehee et al. (2013) this methodology identifies potential gaps in tourism product offerings while preserving those assets considered "off limits" to tourists by residents, thereby placing emphasis on the needs and preferences of members of the local community.

In order to implement the research activities, the West Virginia University Rural Tourism Design Team received a grant from the Claude Worthington Benedum Foundation to develop a common vision for cultural tourism, thematically link tourism assets, develop a leadership network, and create a performance agenda for the CDA. Design Team members include WVU Extension Community Resources and Economic Development specialists, and faculty and students from the Recreation, Parks, and Tourism Resources Program, Department of Landscape Architecture, and Graphic Design Program. Planning activities were designed to acquire information from three groups of primary stakeholders in the destination (leadership, residents, and visitors) in order to accurately represent the positive, successes, and strengths to develop action strategies and provide assistance for community-based tourism that represent the interests of a broad and diverse group of community stakeholders. The planning and design activities included an equivalent status/simultaneous mixed methods approach developed and implemented by the Team. This approach (Figure 8) included eight primary research phases conducted over a one year period. 


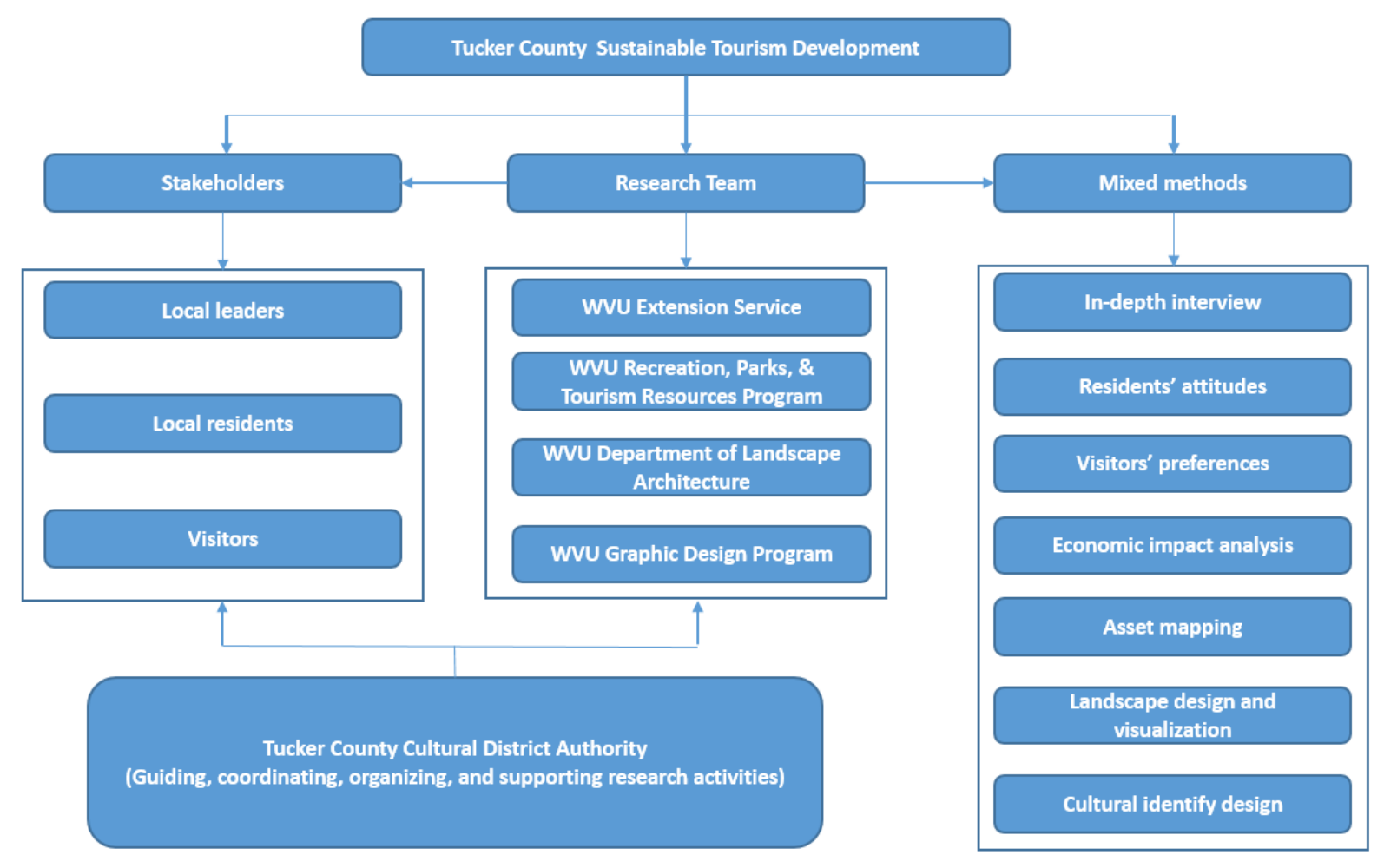

Figure 8 Project Phases

\subsection{Methodology}

\subsubsection{Phase 1: Key informant interviews}

In order to collect detailed information on specific tourism opportunities and challenges, in-depth, semi-structured individual interviews were conducted over six months by the lead author of this paper, a rural tourism extension specialist. Interviewees included key informants representing a range of tourism-related organizations involved in destination marketing and management including the Convention and Visitors Bureau, Economic Development Authority, CDA, local and county government, community foundation, private businesses, and non-profit organizations. Stakeholders were selected in an attempt to cover diverse perspectives throughout the County utilizing a traditional snowball technique based on recommendations by board members of the CDA. This technique yielded 30 interview candidates (see Table 18), which the 
authors believe to be a representative sample. Interviews were recorded, and the data were transcribed as soon as possible afterward. Data collection and thematic analysis occurred concurrently, with early analysis informing later interview protocols. Data analysis included coding of the data to explore the themes generated in the field and to group different aspects of the data to compare emerging categories with those already unearthed in the literature, ensuring the selection of the most representative and inclusive categories. 
Table 18 Key Informant Interview Candidates

Title, Organization

1. President, Tucker County Cultural District Authority

2. President, Artspring

3. Owner, Canaan Realty

4. Owner, Whitegrass Ski Touring Center

5. Tucker County Commission

6. Development Director, Tucker Community Foundation

7. Owner, The Purple Fiddle

8. Superintendent, Blackwater Falls State Park

9. Executive Director, Tucker Community Foundation and Tucker County Cultural District Authority board member

10. Superintendent, Canaan Valley National Wildlife Refuge

11. Owner, Ben's Old Loom Barn

12. Director, Tucker County Cultural District Authority

13. Marketing Director, Tucker County Convention and Visitors Bureau

14. Tucker County Planning Commission and Friends of the Blackwater

15. Superintendent, Canaan Valley State Park

16. CEO, Canaan Valley Resort

17. Verglass Media

18. Owner, Bright Morning Inn

19. Owner, Hellbender's Burrito's

20. Owner, Stumptown Ales

21. Owner, Verglass Media

22. Owner, Big Belly Deli

23. Owner, Creature Gallery and the Whiteroom Gallery

24. Buxton and Landstreet Gallery and Studios

25. Owner, the Cooper House and the Billy Motel

26. Owner, Three Castle Antiques

27. Director, New Historic Thomas

28. Executive Director, Tucker County Convention and Visitors Bureau

29. Heart of the Highlands and Friends of the 500th

30. Timberline Four Seasons Resort

31. Mayor, Town of Thomas

\subsubsection{Phase 2: Resident attitudes toward tourism survey}

A survey instrument was developed that included Likert scale items designed to measure residents’ perceptions toward tourism development, (Gursoy, Jurowski, \& Uysal, 2002; Gursoy \& Rutherford, 2004; Lankford \& Howard, 1994; Nunkoo \& Ramkissoon, 2010), support for tourism development (Nunkoo \& Ramkissoon, 2011; Wang \& Pfister, 2008) and social capital 
(Jones, 2005; Flora, 2004; Onyx \& Bullen, 2000; and Park, Nunkoo, \& Yoon, 2015). The survey instrument also included an importance- performance analysis of tourism attributes, ranking of tourism development opportunities, open-ended questions, and demographics. The methodology followed the Dillman, Smyth, and Christian’s (2014) “tailored design method” including two weeks after the questionnaire was mailed to the respondents, a reminder postcard was sent, followed by a re-mailing of the entire package to those residents who did not respond within four weeks. The survey was distributed to all residents of Tucker County with a valid mailing address using the US Post Office Every Door Direct Mail program which yielded a total of 3,621 addresses. 637 resident surveys were completed and returned for a 17.6\% return rate. Primary data collected from the survey were entered into the Statistical Package for Social Science (SPSS) software package for organization and analysis.

\subsubsection{Phase 3: Visitor preferences survey}

A survey to assess visitor preferences was designed by the research team, and administered by faculty and students in the research team in the fall and winter of 2015 and spring and summer of 2016 at various events and attractions of the County. The purpose of this phase of the study was to better understand visitors' perceptions of tourism and preferences. The survey instrument included Likert scale items designed to measure visitor's perceptions of tourism development, purpose of visit, main attractions visited, trip size and duration, demographic information, and visitor comments. A total of 266 surveys were completed. The response rate is unknown.

\subsubsection{Phase 4: Economic impact analysis (current and development options)}

West Virginia University Extension Service specialists designed an online survey instrument based on a review of previous recreation and community-tourism business and 
economic impact surveys, and input from tourism development stakeholders including the Tucker County Chamber of Commerce, Convention and Visitors Bureau, and CDA. The webbased survey was distributed via email in May 2016 by Chamber of Commerce representatives. Targeted business sectors included: lodging, retail establishments, real estate offices, outdoor outfitters, restaurants and food-based businesses, and other establishments including visitor services, arts and civic organizations, and other business services. These businesses represented 62 (29\%) of the county's 216 wage paying businesses. Surveys were initiated by 53 businesses (85\% of the surveyed population); twelve (12) businesses did not complete any parts of the survey resulting in total of 41 (66\%) usable survey responses.

Survey respondents were asked to describe the age of their business and reasons for locating in Tucker County; primary markets; seasonality; anticipated performance of their businesses and the county's broader tourism industry in the coming year; business costs; and, employment and sales data. The economic contribution of the tourism industry was quantified using input-output analysis; specifically, a hybrid model of the Tucker County economy. The hybrid model was based on the original county specific input-output model from IMPLAN for 2015 and adjustments to employment and earnings data from survey respondents, the most current data from federal and state employment agencies (Bureau of Labor Statistics, Quarterly Census of Employment and Wages; Workforce West Virginia), and private data sources, including ReferenceUSA.

\subsubsection{Phase 5: Participatory Asset Identification and Mapping}

The research team developed an online form (see figure 9) that was utilized by the CDA Americorps volunteer to collect and enter data on tourism assets that exist in the County. Tourism and recreation related assets include local, state and federally managed recreational 
facilities (parks, trails, recreational sites, other specially designated areas), cultural venues, and historic sites; as well as business locations of interest to visitors including restaurants, accommodations, specialty retail establishments, grocery stores, convenience stores, agritourism sites, etc. Mapping these resources involved developing an up-to-date, comprehensive inventory of the assets themselves, including recording an accurate spatial location for each feature. Community involvement in the asset mapping process included data collection on additional assets, classification of status of each asset (i.e. "visitor ready"), as well as identification of potential data gaps. Results of asset mapping are presented to interested parties and/or the general public using ArcGIS Online, an interactive online mapping tool.

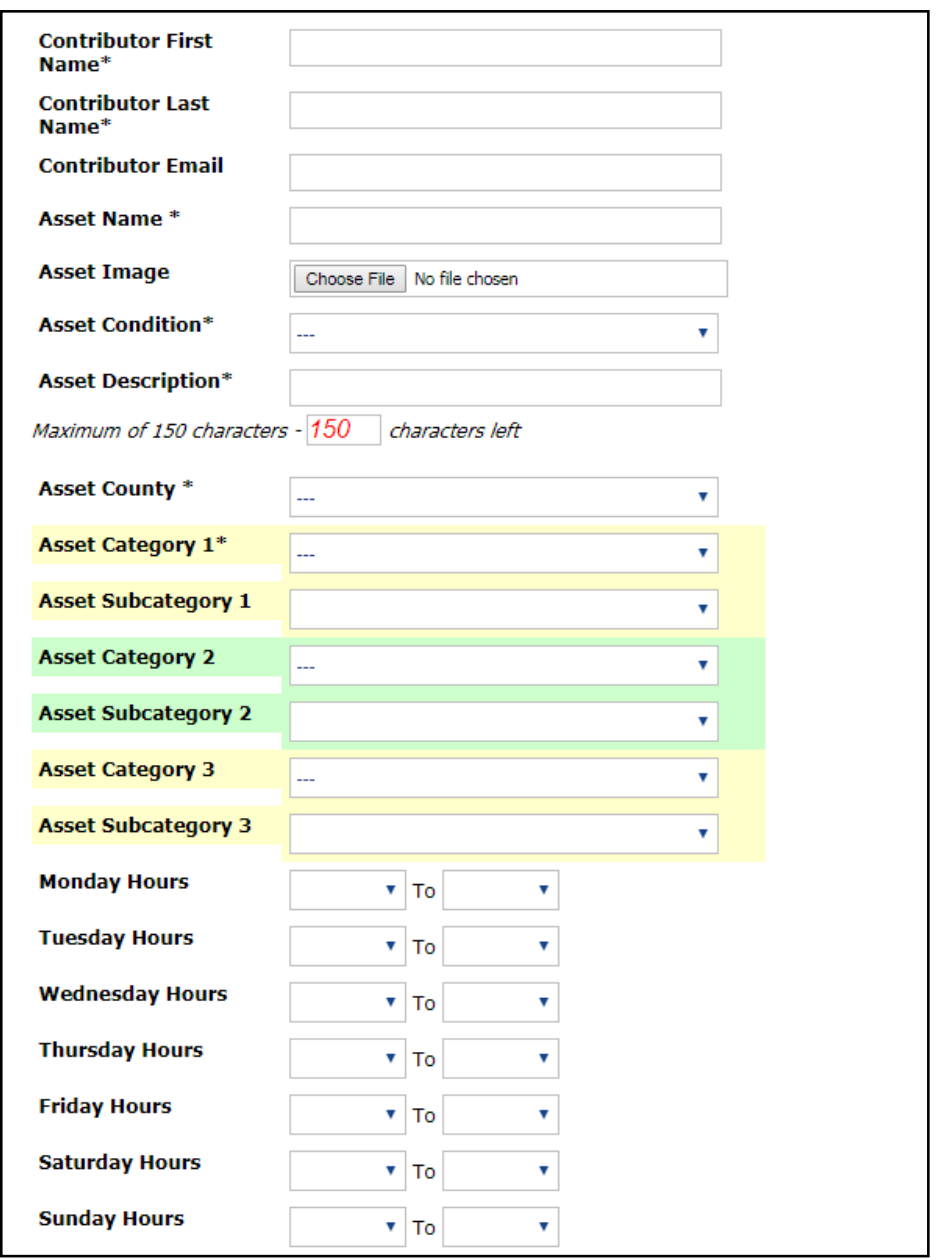

Figure 9 Tourism Asset Inventory Data Collection Form 
4.2.6 Phase 6: Mapping of opportunities and priorities for tourism development and landscape design/visualization of sites targeted for development

The Community Engagement Lab (CEL) within the School of Design and Community Development at West Virginia University provided disciplinary diversity to the project in the form of landscape architecture faculty and students contributing to this phase of the project. The CEL connects faculty and students to projects in communities in the areas of planning and design with the goal of capacity building. The contributions of the landscape architecture program in the transdisciplinary model in tourism planning included a multilayered approach to participation. Focus group meetings identified opportunities for site development, corridor management and district wide proposals. Workshops with particular stakeholder groups created designs and visualizations for the particular opportunities. Workshops conducted through the CEL (summer 2016) in coordination with Extension Service specialists provided participatory spatial analysis of local and countywide resources. The workshops were conducted in the Tucker County communities of Canaan Valley (unincorporated), Davis, Parsons, and Thomas. The workshops included questions and activities to solicit public input on tourist areas and sites, resident use of these sites, and gaps and priorities for site development (see figures $10 \& 11$ ) 
Tucker County WV Cultural Tourism Planning 'Drop in and Contribute' Activities and Questionnaire

Cultural Tourism and Recreation
Identify tourist 'areas and sites of interest'
within the community/county.
Identifying Gaps

What are some 'gaps' or 'needs' that you perceive in your community in relation to recreation and heritage themed site development?
What are charactering-defining features of Tucker County? Organize as Social, Natural, Cultural or Historic features.

Identify and list other recreational, natural, cultural, historic, and industrial landscapes with a focus on culture, heritage, and recreation.

What would be the value to the community in addressing these 'gaps' or 'needs'?

Where are places that are 'sacred' to your community? What are threats to these 'sacred' places? What are opportunities in preserving them?

Where would you bring a visitor to you community? Where would you bring a visitor within the county?

Identifying Priorities

What are priorities for recreation and cultural tourism development in your community?

Where do your recreate in your

community? Are there walking routes that you use regularly?

What are priorities for the county in recreation and cultural tourism development? Identify particular project 'sites' and 'corridors' for mapping

What do you perceive as barriers to exercise?

Identifying Character/Themes What are character defining features of

Are there opportunities for enhancing the environment of your community for recreation and physical activity?

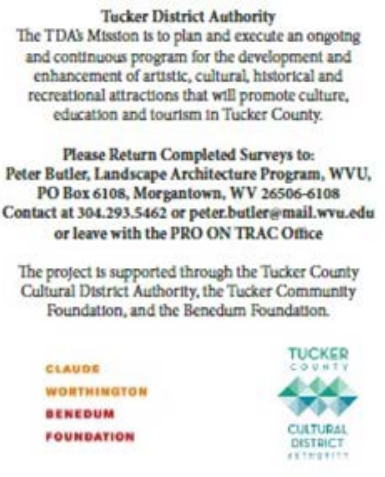

Figure 10 Tourism gaps and priorities input form 


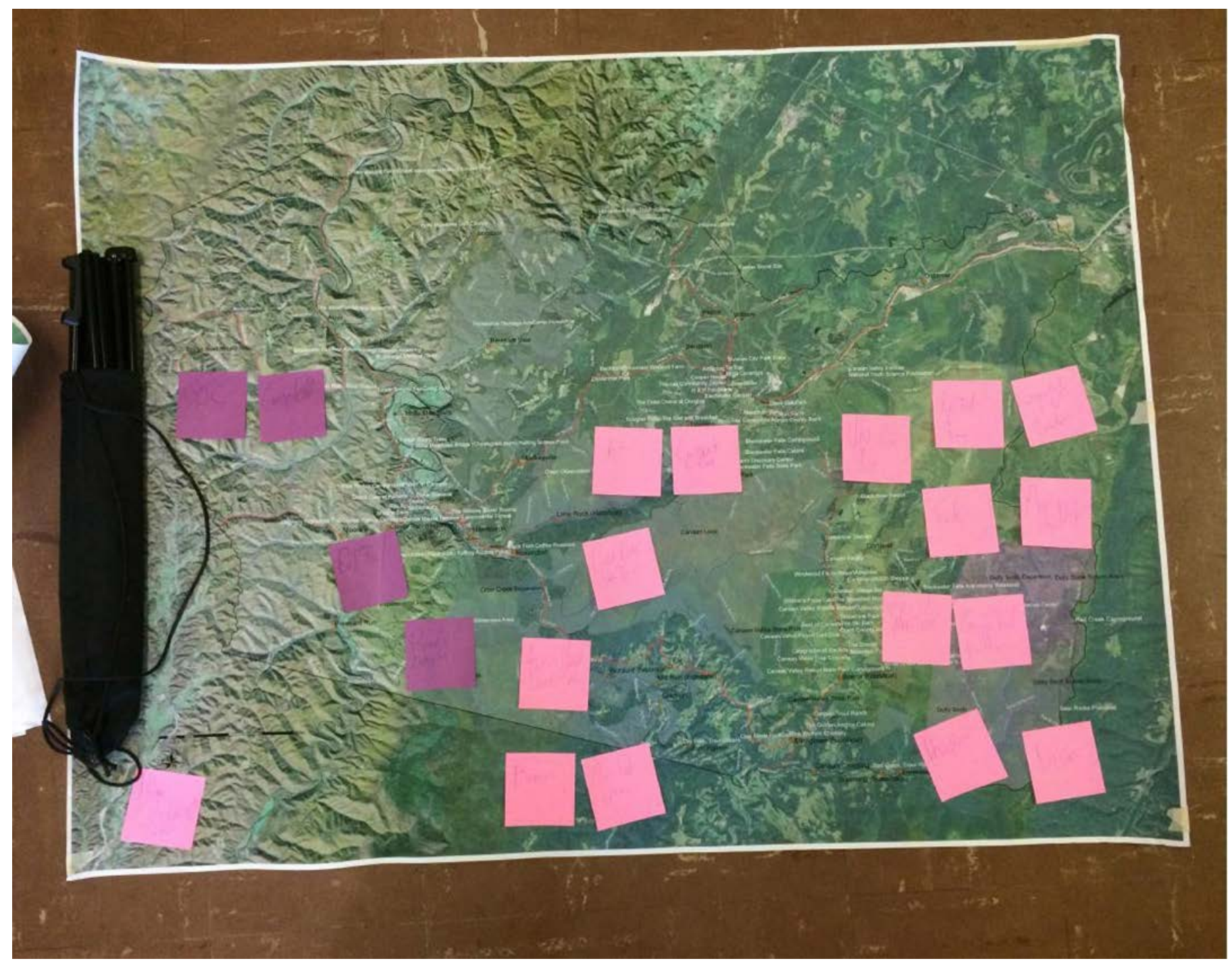

Figure 11 Mapping Results from Workshop

\subsubsection{Phase 7: Social design to create a cultural identity}

To ensure that residents both understood what an identity could be and to collect their beliefs about what their community held dear, five workshops were given across the county that generated and prioritized important descriptive words and asked six questions about visual representation that included approximately eight or more visual examples to rate to help guide the direction to move forward (see figure 12). 


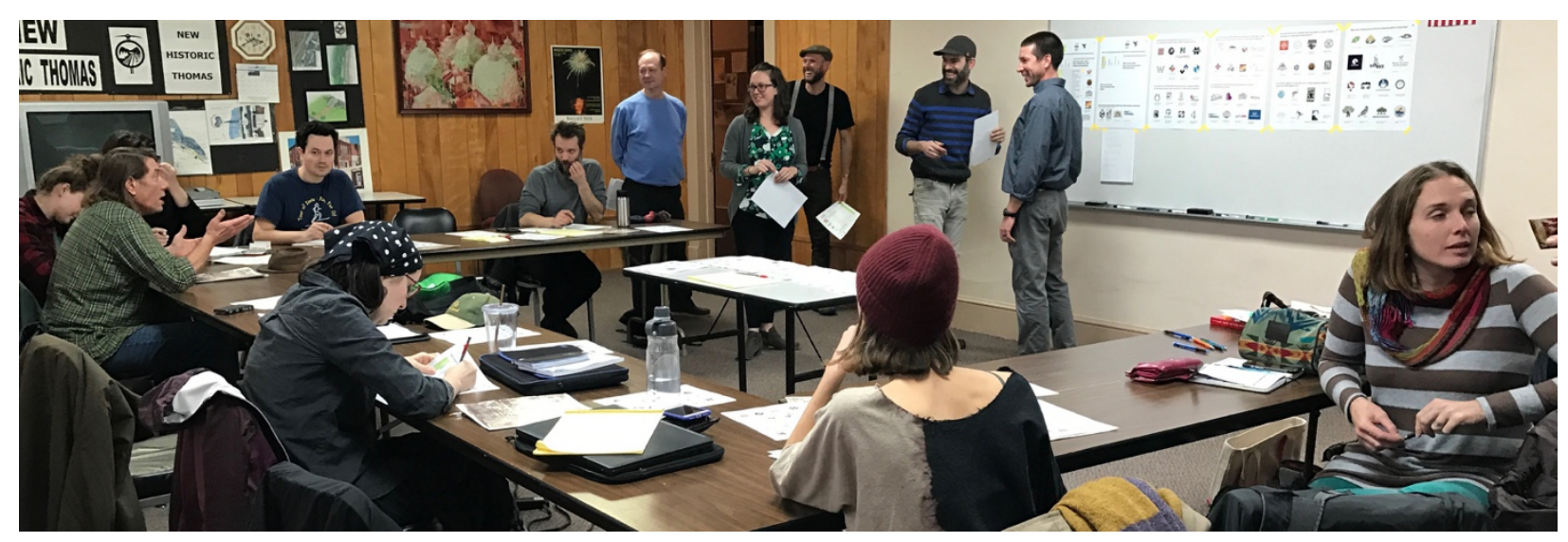

Figure 12 Cultural identity design input workshop

WVU graphic designers sifted through this information as well as data collected from interviews on site and previous collected interviews conducted by the Extension Tourism Specialist. In addition to the interviews, surveys, and meetings, a series of workshops to engage the public in actual preferences in visual communication were conducted in three areas of the county. Media invitations were extended through local newspapers and emails to organizations in communities surrounding the workshop venues.

These workshops consisted of soliciting and ranking descriptive words associated with each section of the county as identifiers, and collecting personal preferences for visual styles based on questions regarding the tone and message. The conversation during the workshops also generated additional stories and qualitative data. The first page of the input form presented a county-wide column and a column for the participant's own town or community. Rows contained words gleaned from interviews, surveys, observations and community discussions which participants ranked 1-5 for resonance. This page also asked for a favorite among four visual choices. (See figure 13). 


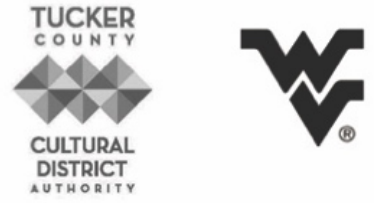

Tucker County Cultural District Authority and WVU POLL for Community Identity Preferences

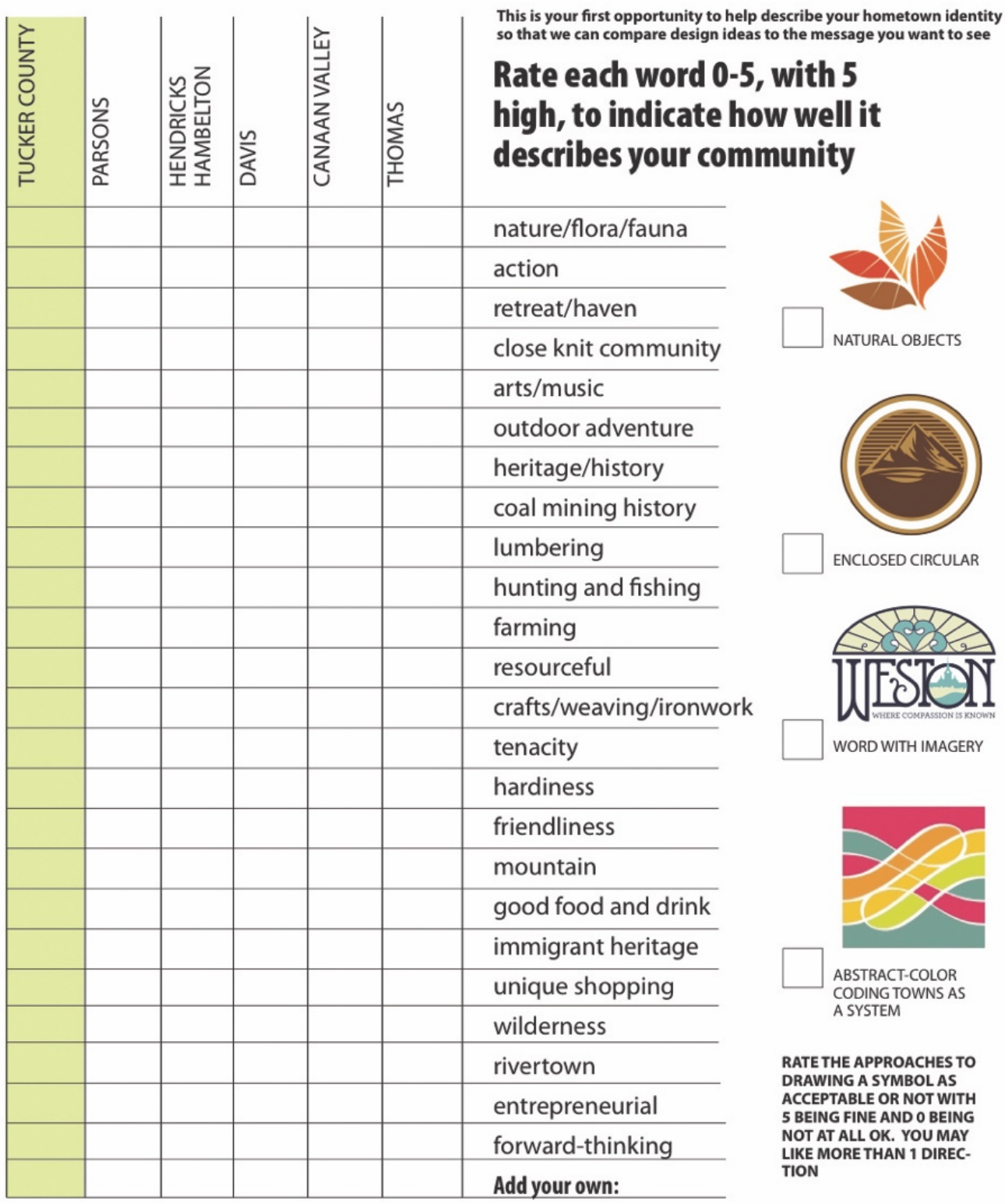

Figure 13 Cultural identity design input form 
A second page asked for input on objects that the participant thought of in connection to the County and also to the town where they lived. Additionally, it presented existing branding in the state, county and towns and asked which were favored for style.

Four more pages presented 63 identity styles that might be used for community branding and broke them into groupings according to major ideas, posed as choices, generally eight options in each. The wording allowed participants to see what aspect of each symbol should be paid attention to, but also allowed the reader to go for a "gut feeling" without overanalyzing the symbols. The purpose was to identify trends in symbols that resonated more than others in popularity, but it was also important as an exercise to make the community feel involved, to generate focused conversation after looking at many examples instead of only thinking of what they may have been exposed to locally, or for chain stores or companies unrelated to towns or the local environment to "force" branding. Additionally, it allowed the participants to recognize the work involved in developing a visual message, and that it would not be a capricious endeavor. Like other elements of the project, these sessions facilitated a relationship of trust between the University and the community, showing that listening to community desires was taken seriously.

\subsection{Results}

\subsubsection{Key informant interviews}

Key themes identified in the key informant interviews included maintaining authenticity

and sense of place, economic diversification, seasonality and low wage jobs, consistent hours of operation, finding and retaining employees, employee awareness of tourism assets, affordable housing, developing infrastructure and public services, signage, resorts being more engaged with community activities and attractions, creating a common identity, and coordination of activities. 
Concern about maintaining a sense of place as Corridor $\mathrm{H}$ is completed was top of mind for the majority of those interviewed. According to one local stakeholder,

People are aware of keeping things authentic. Having small antique shops and breweries and restaurants that are non-chain, people appreciate and want to experience that. The closest McDonald's is 20 minutes away. There's no chain hotels and that's what makes us unique. It's true, it's authentic, it's one-of-a-kind, and you're not going to find anything else like it. The commercialization that has followed improved access in other destinations is a real concern. One stakeholder noted the reality of how difficult this challenge could be, "I think taking advantage of Corridor $\mathrm{H}$, because it's here; taking advantage of that and not losing our quality of life in the process is going to be our biggest challenge.” Another commented on the need for a strategy that supports sustainable growth, "we know we need some more opportunity, but let's do it in a way that supports the inherent value of this place, I think we can do that through growth management, and zoning and, ordinances."

The importance of attracting the right kind of visitor was apparent. According to one stakeholder, "the type of tourists I personally want to encourage are the stewards of the outdoors, people who are concerned about what they leave behind and what sort of footprint they're making." In addition to attracting this type of visitor, key informants see the opportunity to develop a quality of life that will encourage visitors to become permanent residents. According to one local stakeholder, “tourism brings in people who have new ideas, and with technology it’s easier for them to set up and operate here; the coal mining is gone here and that's a hard, hard pill to swallow.”

Some important challenges were identified in trying to provide services to visitors and manage sustainable tourism growth. According to one local stakeholder, "I think one of the 
biggest challenges in running a tourist business is the seasonality. We can be just overwhelmed with people on certain weekends and then we can be very slow.” Finding employees to work in the service industry was also noted as a challenge because as one local stakeholder noted, "this is a tiny little area and very few people live here.” One local stakeholder talked about a need for the next generation to step up and participate as volunteers to help coordinate events and activities because, "it is all of the same people working hard right now, and we need to keep that momentum going, they can’t do it all by themselves.”

In addition to the challenges noted with seasonality, employees, and sustaining volunteers, key informants discussed the need for a common vision. One local stakeholder described the current situation as, "we’ve realized that there are many visions and many parallel visions of where Tucker County is going, so we are working on a more unified vision for where we're going.” Another local stakeholder commented that, "there's a lot of things going on but there's not necessarily a unity to the whole thing." One stakeholder identified a possible reason for the lack of coordination and cohesion, "if there was an individual or an organization that wanted to take on that lead role as part of their business to coordinate efforts to put us all together cohesively that would be fantastic."

\subsubsection{Resident attitudes toward tourism}

Table 19 lists the demographic breakdown of the resident survey sample. The demographic breakdown of the survey sample is consistent with the demographic breakdown of the resident population described in section 1.2 and table 1 . The male/female ratio of the local population was a little closer than the survey sample at $49.8 \%$ female and $50.2 \%$ male. Tucker County has an older population with $46.7 \%$ above age 50 and $75.8 \%$ of survey respondents above age 50. Less than half of the local population (37.2\%) have attended college with $72.1 \%$ 
of survey respondents attending some college and $46.4 \%$ have annual family income of less than $\$ 40,000$ which is consistent with the survey sample. Sixty-six percent of local residents have lived in their current residence for 17 or more years with $64.9 \%$ of survey respondents having lived in Tucker County for 21 or more years.

While a strong majority (85.7\%) agreed or strongly agreed that Tucker County is rich in outdoor recreation resources, just over half (51.3\%) agreed or strongly agreed that the County effectively utilizes its outdoor recreation resources for tourism. While the CDA was organized to promote and develop outdoor recreation, cultural, and historical experiences, a much lower percentage (60.6\%) agreed or strongly agreed that Tucker County is rich in historical resources, with just 28.3\% agreeing or strongly agreeing that Tucker County effectively utilizes these historical resources for tourism. An even lower percentage (40.8\%) agreed or strongly agreed that Tucker County is rich in cultural resources, with just $27.3 \%$ agreeing or strongly agreeing that Tucker County effectively utilizes these cultural resources for tourism. 
Table 19 Socio-demographic characteristics of the resident survey sample $(\mathrm{n}=637)$

\begin{tabular}{|c|c|c|}
\hline \multirow[b]{2}{*}{ Variable } & \multicolumn{2}{|c|}{ Proportion of the sample } \\
\hline & Frequency $(n)$ & Percentage (\%)* \\
\hline \multicolumn{3}{|l|}{ Gender } \\
\hline Female & 358 & 58.4 \\
\hline Male & 255 & 41.6 \\
\hline \multicolumn{3}{|l|}{ Age } \\
\hline 1 to 24 & 6 & 1.0 \\
\hline 25 to 34 & 43 & 7.0 \\
\hline 35 to 44 & 58 & 9.4 \\
\hline 45 to 50 & 43 & 7.0 \\
\hline 51 to 60 & 132 & 21.4 \\
\hline 61 to 69 & 179 & 29.0 \\
\hline $70+$ & 157 & 25.4 \\
\hline \multicolumn{3}{|l|}{ Education } \\
\hline Less than high school & 19 & 3.1 \\
\hline High school & 152 & 24.8 \\
\hline Some college & 129 & 21.1 \\
\hline Undergraduate & 143 & 23.4 \\
\hline Graduate & 169 & 27.6 \\
\hline \multicolumn{3}{|l|}{ Income } \\
\hline Less than $\$ 20,000$ & 85 & 15.4 \\
\hline$\$ 20,001-\$ 40,000$ & 155 & 28.0 \\
\hline$\$ 40,001-\$ 60,000$ & 119 & 21.5 \\
\hline$\$ 60,001-\$ 80,000$ & 62 & 11.2 \\
\hline$\$ 80,001-\$ 100,000$ & 51 & 6.2 \\
\hline More than $\$ 100,000$ & 81 & 14.6 \\
\hline \multicolumn{3}{|l|}{ Length of Residency } \\
\hline 1 year or less & 19 & 3.1 \\
\hline 2 to 5 years & 48 & 7.9 \\
\hline 6 to 10 years & 50 & 8.2 \\
\hline 11 to 15 years & 50 & 8.2 \\
\hline 16 to 20 years & 47 & 7.7 \\
\hline 21 to 30 years & 70 & 11.5 \\
\hline 31 to 40 years & 84 & 13.8 \\
\hline 41 or more years & 241 & 39.6 \\
\hline
\end{tabular}

While $63.4 \%$ agreed or strongly agreed that they support tourism development as having a vital role in their community and $66.8 \%$ agreed or strongly agreed that tourism development will provide more economic opportunities for local people; when asked if tourism is well developed in their community only $33 \%$ agreed or strongly agreed. However, when asked if 
their community has great potential to develop tourism 64.1\% agreed or strongly agreed and $60.8 \%$ agreed or strongly agreed that their community should do more to promote its tourism assets to visitors.

While residents support tourism development as an economic opportunity there was some concern about the type of tourism to be developed and the need to control any potential negative impacts. When asked if it is important that community values are protected when tourism is developed $65.1 \%$ strongly agreed and 58.7\% strongly agreed that long-term planning and managed growth is important to control any negative impacts of tourism. Only $36.3 \%$ agreed or strongly agreed that Tucker County should pursue large-scale entertainment style tourism development that will attract large numbers of visitors. When asked about tourism development opportunities the highest ranked as very needed or high priority included nature tourism, unique local shopping, local restaurants, festivals/events, and accommodations. The lowest ranked as very needed or high priority included casino/gambling (8.1\%), theme parks (18.5\%), and chain/big box shopping (18.7\%).

When asked about social capital (networks, acceptance, and cooperation) in Tucker County, just 34.1\% agreed or strongly agreed that there are strong social networks between communities in Tucker County. In addition, only 31.7\% strongly agreed that they feel accepted as a valued resident of their community and just 19.5\% strongly agreed that different opinions are valued in my community. When asked if individuals and organizations in their community cooperate to achieve collective goals just $18.6 \%$ strongly agreed.

When asked if there is a common vision among communities for tourism in Tucker County just $26.3 \%$ agreed or strongly agreed, only 33.5\% agreed or strongly agreed that there is 
a common vision in their community, and less than half of survey respondents (44.2\%) agreed or strongly agreed that there is a collective identity in Tucker County.

Survey respondents were asked to respond to some open-ended questions. When asked to describe, "What does tourism mean to you?" it was clear that residents have mixed opinions about tourism as an economic development strategy. Positive comments were related to economic development (80), sharing their community with outsiders (76), and jobs (65) while negative comments were related to problems (43), low paying - seasonal jobs (27), and nothing/not needed (25). When asked to describe “How can tourism benefit you personally?” 79 responses included no benefit (79), jobs (60), more local businesses (32), more activities for residents and friends and family (31), and improving the quality of life (28).

An opportunity for open-ended comments provided additional perspectives on residents' perceptions of rural tourism challenges and opportunities. Responses included-need good jobs not tourism (21), don't want tourism (19), tourism = low wage and seasonal jobs (11), the impact of tourism is concentrated on the top of the mountain vs the bottom of the mountain (16), manage the growth (27), no commercialization (11), and more amenities/attractions for residents and visitors (22).

\subsubsection{Visitor preferences}

Table 20 lists the demographic breakdown of the visitor survey sample. When visitors were asked about their opinions of Tucker County's natural, cultural, and historic assets, 94.5\% of respondents either agreed or strongly agreed that the destination has a wealth of nature-based attractions, yet only a slight majority (51.2\%) either agreed or strongly agreed that the destination has a wealth of cultural or historic based attractions. Similarly, when visitors were asked about the types of attractions, services, or activities they visited during their trip the 
highest percentage of those surveyed visited restaurants, nature attractions, festivals/events, and breweries/wineries with just 19.5\% visiting historic attractions and 17.5\% visiting cultural attractions.

Table 20 Socio-demographics and trip characteristics of the visitor survey sample.

\begin{tabular}{lrr}
\hline \multicolumn{1}{c}{ Variable } & \multicolumn{2}{c}{ Proportion of the sample } \\
\cline { 2 - 3 } Gender & Frequency $(n)$ & Percentage $(\%)^{*}$ \\
$\quad$ Female & 154 & 60.2 \\
$\quad$ Male & 102 & 39.8 \\
Age & & \\
17 and under & 1 & 0.4 \\
18 to 24 & 14 & 5.5 \\
25 to 34 & 44 & 17.2 \\
35 to 44 & 42 & 16.4 \\
45 to 50 & 35 & 13.7 \\
51 to 60 & 65 & 25.4 \\
61 to 69 & 46 & 18.0 \\
$70+$ & 9 & 3.5 \\
Education & & \\
Less than high school & 2 & 0.8 \\
High school & 32 & 12.6 \\
Some college & 28 & 11.0 \\
Undergraduate & 78 & 30.7 \\
Graduate & 114 & 44.9 \\
Income & & \\
Less than $\$ 20,000$ & 14 & 5.9 \\
\$20,001 - $\$ 40,000$ & 25 & 10.6 \\
\$40,001 - $\$ 60,000$ & 34 & 14.4 \\
\$60,001 - \$80,000 & 32 & 13.6 \\
\$80,001 - \$100,000 & 51 & 61.9 \\
More than $\$ 100,000$ & 99 & \\
& & \\
\hline
\end{tabular}


Table 20 (continued).

\begin{tabular}{lrr}
\hline Location of Primary Residence & & \\
West Virginia & 113 & 44.3 \\
Virginia & 42 & 16.5 \\
Maryland & 40 & 15.7 \\
Pennsylvania & 17 & 6.7 \\
Washington, DC & 11 & 4.3 \\
Ohio & 10 & 3.9 \\
New Jersey & 3 & 1.2 \\
New York & 3 & 1.2 \\
Florida & 2 & 0.8 \\
Ontario & 2 & 0.8 \\
California & 1 & 0.4 \\
Illinois & 1 & 0.4 \\
Kansas & 1 & 0.4 \\
Kentucky & 1 & 0.4 \\
Korea & 1 & 0.4 \\
Michigan & 1 & 0.4 \\
Minnesota & 1 & 0.4 \\
Missouri & 1 & 0.4 \\
Nebraska & 1 & 0.4 \\
Oklahoma & 1 & 0.4 \\
Tennessee & 1 & 0.4 \\
Wyoming & 1 & 0.4 \\
\hline
\end{tabular}

When asked if the destination has "great potential for tourism development" $62 \%$ of survey respondents strongly agreed. In addition, $91.9 \%$ agreed or strongly agreed that the destination is unique and $58.9 \%$ agreed or strongly agreed that the quality of tourism in this destination will be negatively impacted without long-term planning and managed growth. Only $38.2 \%$ agreed or strongly agreed that communication infrastructure (cellular, WiFi) was adequate in this mountain destination and only $54.9 \%$ agreed or strongly agreed that the destination effectively promotes its tourism resources. When asked to identify specific opportunities for tourism development respondents identified heritage tourism (39\%) and cultural tourism (34.4\%) as opportunities, with only $5.5 \%$ of respondents identifying chain/big box shopping as an opportunity, $5.5 \%$ theme parks, and $4.7 \%$ casino/gambling. 
Although survey respondents identified some challenges as well as opportunities, $64.2 \%$ strongly agreed that they were satisfied with their experience visiting the destination, $72 \%$ strongly agreed that they will recommend the destination to their family or friends, and $78.5 \%$ strongly agreed that they will revisit the destination in the future.

Respondents were provided an opportunity to provide additional comments. According to one visitor, "we come here to get away from the big chain stores and commercial impact that has been increasingly changing the landscape of our home turf." Another commented on the need for managed growth stating that, "if this area would become overrun with tourists then it would lose its uniqueness and charm, I come here to get away from large food chains and urban climate.” Another questioned whether it's possible for tourism to be developed without losing the destinations charm and atmosphere and stated that they would not return if that would happen. One visitor recommended potential action steps that could be taken to control growth stating that, "zoning restrictions are crucial to limit unnecessary growth and sprawl." Economic impact analysis (current and development options)

The economic contribution of the tourism sector is presented in Table 21. Tucker County’s tourism businesses generated an estimated \$65 million in annual sales in 2016. These sales directly supported 824 jobs in the county and more than $\$ 15$ million in employee compensation and proprietors' income. The industry contributed an additional \$19 million in taxes and property income for a combined \$35 million value-added impact. Subsequent rounds of business-to-business spending (indirect effect) and employees' household spending (induced effect) stimulated by sales at tourism businesses generated additional economic impact in the local economy: the purchase of inputs and additional business-to-business spending supported 80 jobs and \$2.3 million in employee compensation and proprietor’s income. Household spending 
by local workers supported an additional 67 jobs and $\$ 1.8$ million in employee compensation and proprietor's income. In total, the industry supported 970 local jobs and generated $\$ 44$ million in income and taxes, including more than $\$ 19$ million in local wages and proprietors’ incomes.

Table 21 Economic contribution of the Tucker County tourism sector.

\begin{tabular}{lcccc}
\hline Impact Type & Employment & $\begin{array}{c}\text { Labor } \\
\text { Income } \\
\text { (millions \$) }\end{array}$ & $\begin{array}{c}\text { Value } \\
\text { Added } \\
\text { (millions \$) }\end{array}$ & $\begin{array}{c}\text { Output } \\
\text { (millions \$) }\end{array}$ \\
\hline Direct Effect & 824 & $\$ 15.26$ & $\$ 34.92$ & $\$ 65.11$ \\
Indirect Effect & 80 & $\$ 2.33$ & $\$ 5.02$ & $\$ 9.44$ \\
Induced Effect & 67 & $\$ 1.78$ & $\$ 4.06$ & $\$ 6.68$ \\
Total Effect & 970 & $\$ 19.37$ & $\$ 44.00$ & $\$ 81.22$ \\
\hline
\end{tabular}

Most businesses were well established in the community; 70\% indicated that they had been in business for ten years or more. Many owners identified quality of life factors as key reasons for establishing their business in the county citing a simple way of life, natural beauty, recreation opportunities, and the low-costs of doing business. Businesses' outlook for the future of the County's tourism industry was overwhelmingly positive: $74 \%$ of responding businesses anticipated continued growth, and more than half anticipated increased sales in the coming year. Only 5\% expected tourism in the county to decline in importance. However, many respondents reported challenges, especially in regard to employment. Seasonality was a commonly cited concern, especially for outdoor outfitters and retail establishments. Wages in the industry averaged just over $\$ 18,000$ per worker and few businesses (35\%) were able to offer employees benefits.

Qualitative data also pointed to both opportunities and threats facing the industry. For example, several respondents noted the positive impact on visitation from the completion of Appalachian Development Highway System, Corridor H. The four-lane highway will put the county within less than 2.5 hours of metropolitan centers in Washington D.C. and Northern 
Virginia; however, many businesses have already noticed that increased access is bringing a different type of tourist, one focused less on outdoor adventure and more on sightseeing, entertainment, and amenities. This anticipated growth and the changing nature of tourism in the county has encouraged many business owners to advocate for increased planning to protect the assets - access to public lands, open space, absence of chains and "big box" stores - which have defined tourism in the traditional mountain communities of Davis and Thomas, and consciously diversify and develop the amenities desired by new and returning visitors. This includes deliberate efforts to identify new opportunities and markets in those communities which have not traditionally benefited from tourism development.

\subsubsection{Community asset inventory and ARC GIS online mapping}

The community asset inventory revealed known and lesser known assets in a variety of categories. This enabled project partners to identify a breadth of distinctive assets and conceptualize how to encourage visitors and residents to explore a wider variety of assets. The asset inventory identified the following categories of assets: trail segments (190), outdoor recreation (44), accommodations (27), restaurant or café - local (24), historical sites (23), retail services (19), festivals and events (17), retail - local (11), education (8), arts (7), retail outdoors (7), health care (6), local products - farmers markets (5), public services (5), restaurants - brewpubs (3), restaurants - chain (3). Using the asset information collected and entered locally in addition to existing statewide datasets and spatial data layers, the WVU GIS technician developed an ARC GIS online map (see Figure 14) of tourism assets including appropriate legends and labels for each map layer. The map was embedded into the Tucker Culture website for residents and visitors to identify and locate cultural resources (https://www.tuckerculture.com/interactive-asset-map/). 


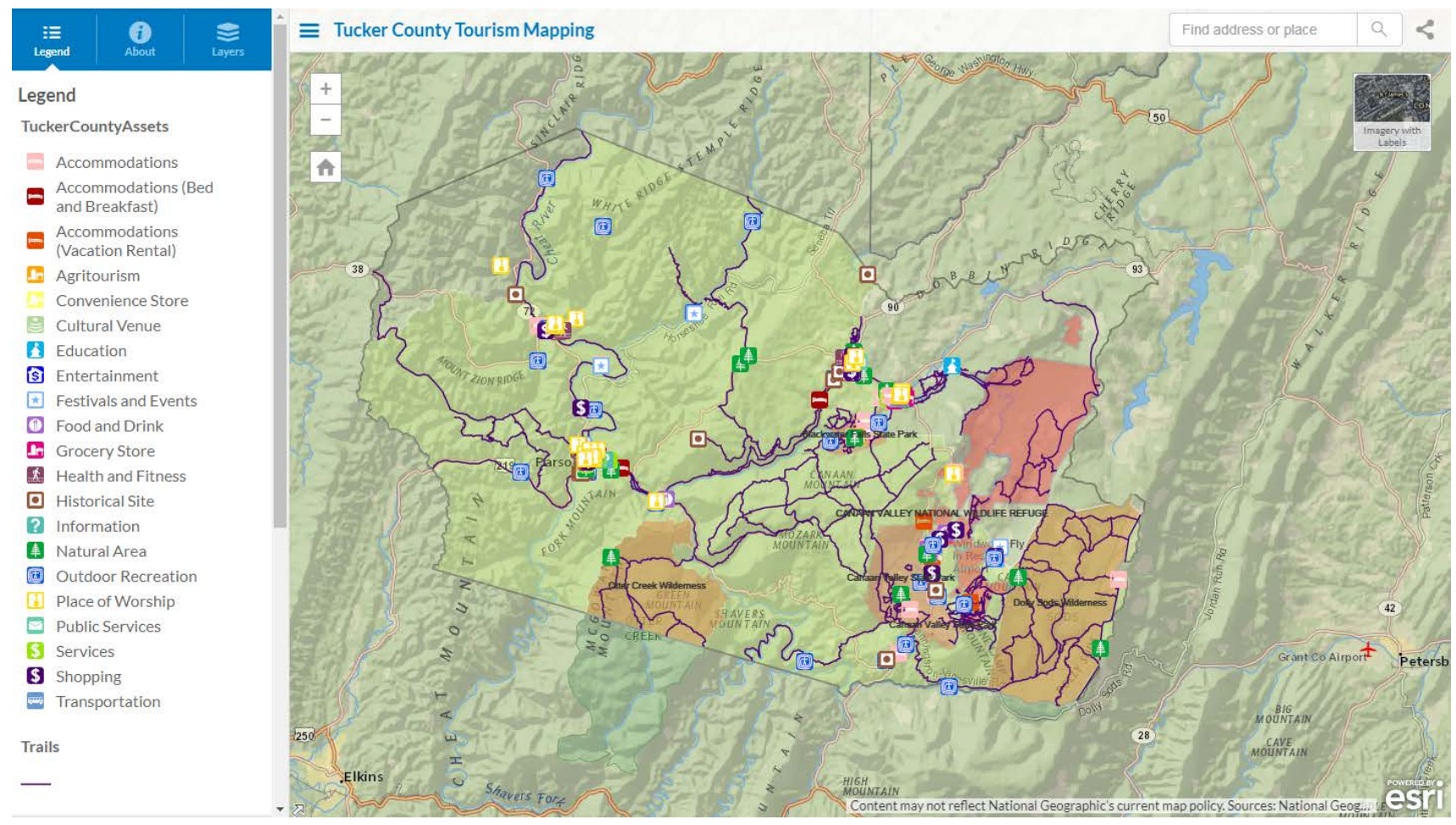

Figure 12 Tucker County, WV ARC GIS online tourism asset map

\subsubsection{Mapping of opportunities and priorities for tourism development and landscape} design/visualization of sites targeted for development

Results of these exercises were entered into the growing GIS database as points (resources), lines (corridors) and polygons (sites and districts). Workshops with the CDA reviewed all the mapped information and set priority rankings for each identified project. Sites with a high priority may have been previously identified as assets though remained undeveloped for community and touristic needs. Participants’ identification of these assets reinforced the need to develop them as resources. A variety of open spaces tied to recreational and heritage resources were identified as thresholds for access and community gathering. Many of the identified assets were undeveloped corridors, especially those used locally for hiking and biking but were not readily signed or accessible for the tourist. For example, a system of road biking loops (see figure 15) were identified by a local resident that would be hidden to anyone without local 
knowledge of the resource. The CDA stakeholders identified these loops as a high priority opportunity as there wasn't a need to develop the resource, only to identify and amplify the routes' potential for recreational tourism.

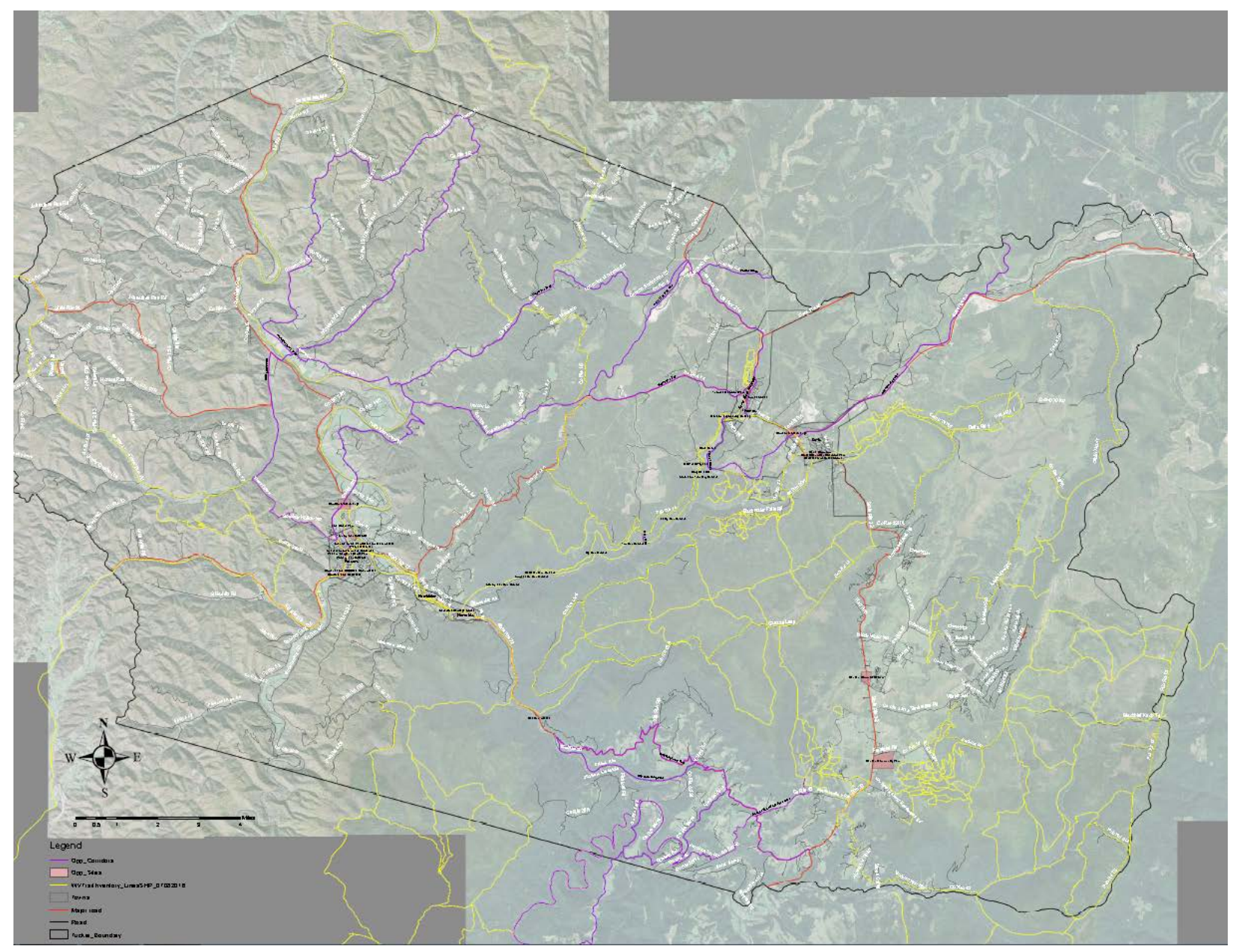

Figure 13 Map of Road-biking Loops

The site development priorities as ranked by the CDA were then designed through the work of a landscape architecture graduate student and design studio courses (spring 2016) as participatory charrettes and service-learning experiences. Classes of sophomore students completed detailed design and visualization for the Engineering and Buxton Landstreet Buildings in Coketon as a trailhead for the North Fork of the Blackwater River rail trail and a 
park design for Shavers Fork in Parsons. Students worked through the design in studio and with community members, creating over twenty alternative scenarios. The graduate student then worked with local stakeholders to create a single vision for the designs. The graduate student also worked on the design of a trailhead park in Parsons at the Western Maryland Depot, a site on the National Register of Historic Places with stakeholders on site (see figure 16).

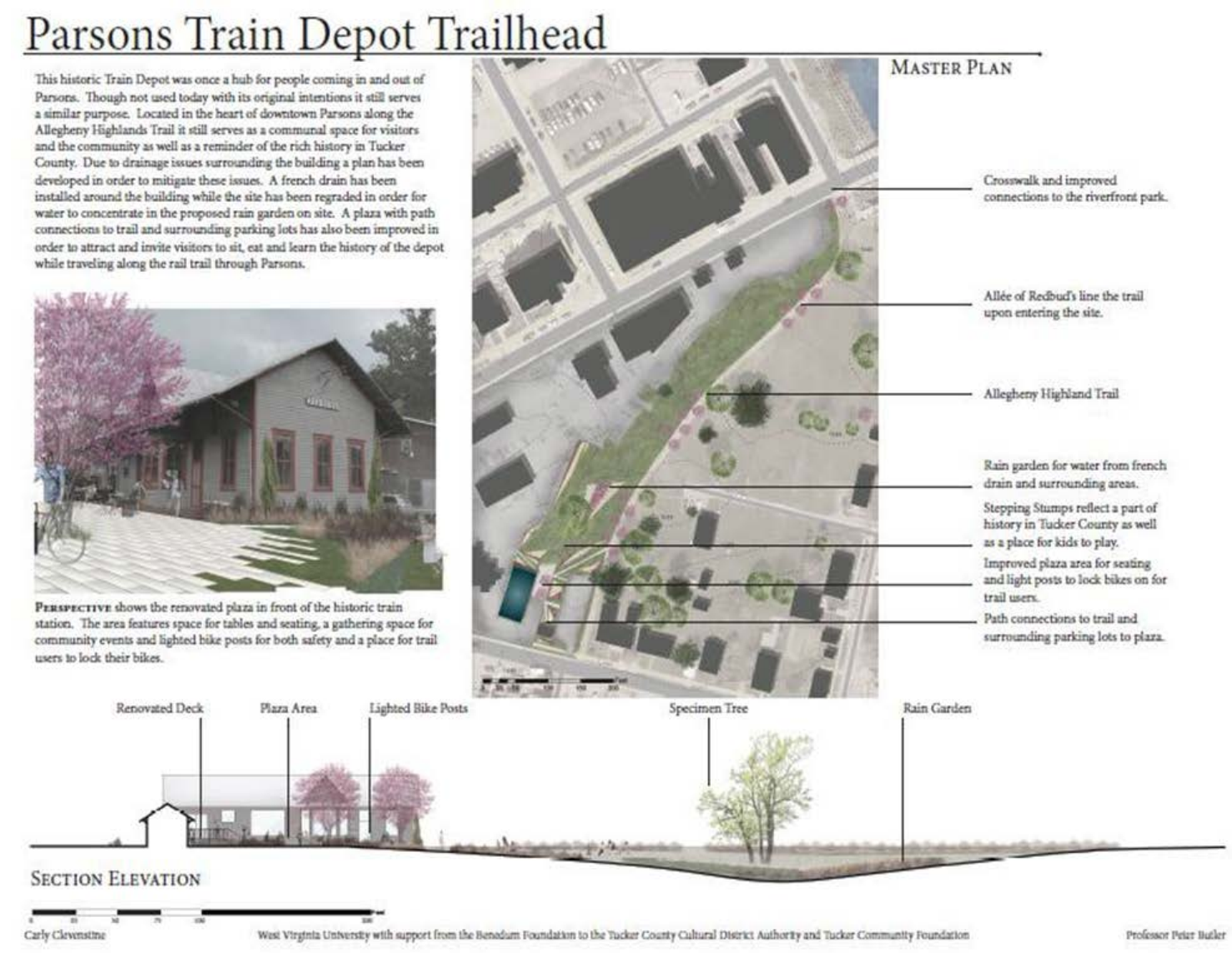

Figure 14 Parsons Train Depot Plan

Another service-learning activity grew from the summer workshops for a class in fall 2016. Workshop data and mapping provided a baseline of information for service-learning through a junior-level landscape architecture design studio. As an experiment in engaged scholarship, the Landscape Architecture Extension Specialist brought the funded research project into the studio environment to further develop plans and designs at the community scale in 
Canaan Valley, Davis and Thomas and begin to visualize the proposed changes. The community plan priorities included: in Davis- enhanced multimodal circulation, affordable housing, a community centre and the design of a waterfront park on the Blackwater River (see figure 17); in Canaan Valley- enhanced multimodal circulation, affordable housing and a health care centre; and in Thomas- enhanced multimodal circulation, revitalization of Spruce Street and infill affordable housing. The communities of Davis and Thomas formed planning commissions for the first time in 2017. The aspiration of the student projects is to share, with the communities and commissions, identified opportunities and technologies that may be applied to community-wide initiatives and site-specific development. The Landscape Architecture Extension Specialist presented the work to the commissions and will act as a resource for future engagement.

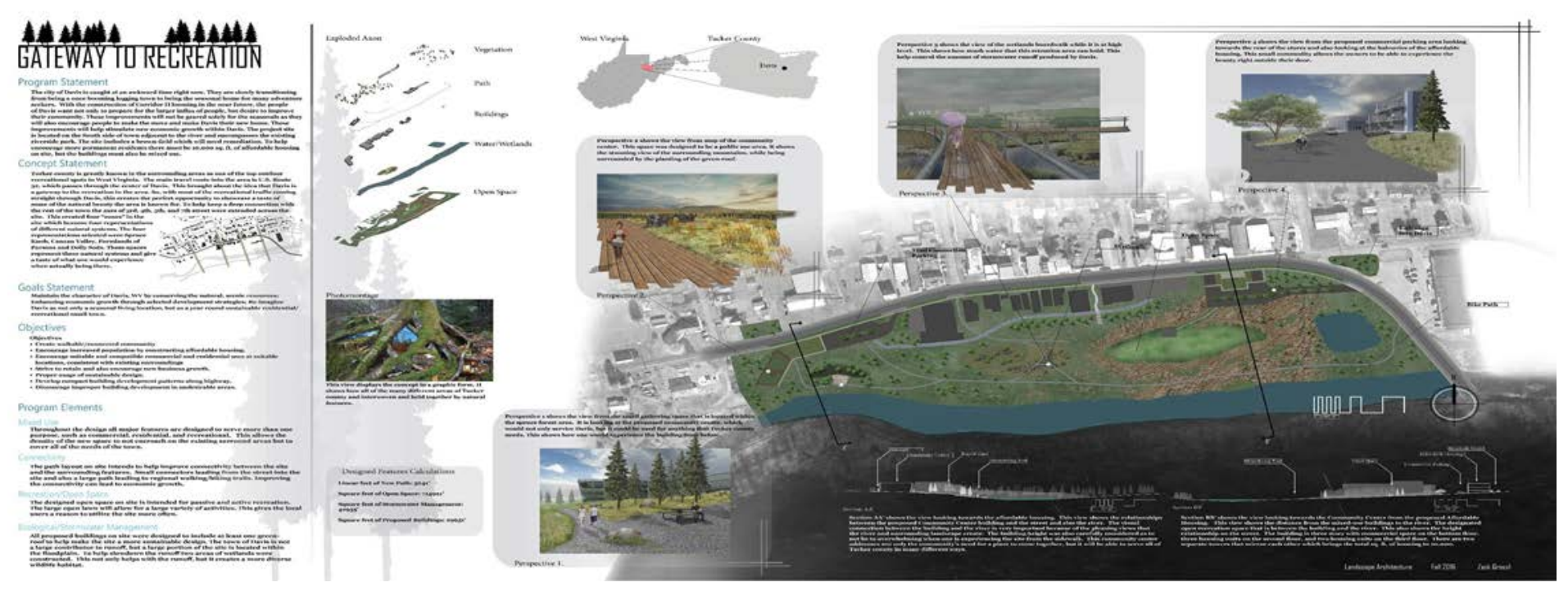

Figure 15 Community Plan for Davis, WV

\subsubsection{Social design to create a cultural identity}

Discoveries through interviews and workshops revealed common beliefs but also divisions which ranged from historic memory of painful events such as school consolidation and the hostile moving of the county seat (over 100 years ago), to a generational divide between 
entrepreneurs, to a geographic divide between the valley towns and mountain towns which have differences in visitor/tourism relationships to their economies.

The charge for the graphic design team was to acknowledge the differences and reframe them as important history; opportunities to learn from one another's experiences; contributing such lessons to addressing the coming changes with Corridor $\mathrm{H}$ and subsequent planning needs. The common ground could also be reframed as advantages that connect experiences of shared resilience and the tapestry of Tucker Culture that comes from tenacity in surviving harsh winters, loving nature and rural wilderness.

Three sets of proposed identities with applications of signage, apparel and print materials were presented to communities who had participated at a mid-process workshop (see figure 18). Information collected from this event led the graphic design team in a new direction and also created trust and buy-in from the residents and board who attended.

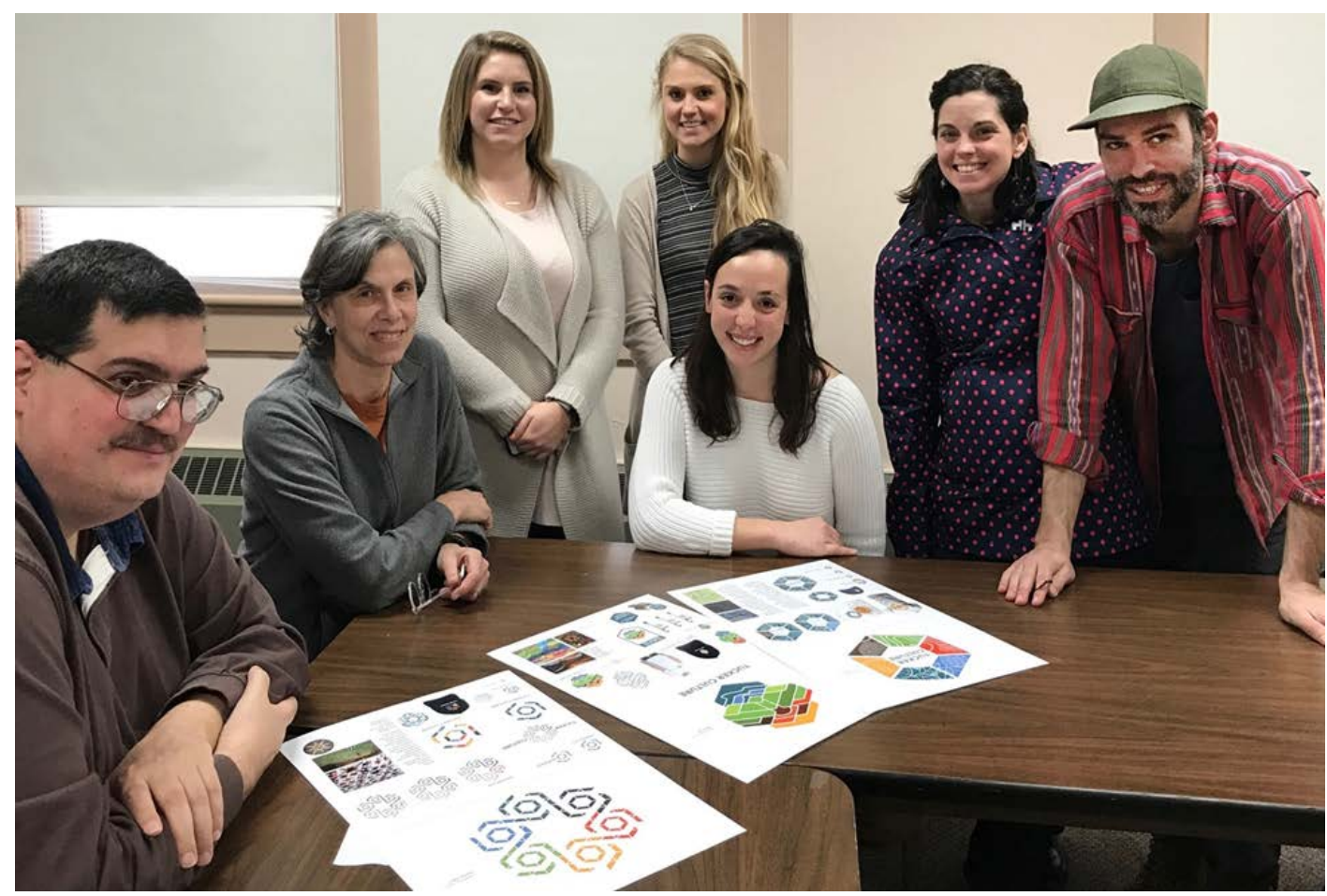

Figure 16 Participatory Cultural Identity Design Workshop 
Regrouping, the team explored three new proposals that were interpretations of the new set of criteria gained at the meeting. A second invitation was extended to see this set of proposals that embraced the moniker of Tucker Culture, a hexagon divided into segments that held linear patterns of icons representing wilderness, mountains, hiking, skiing, biking, rivers, farming, arts, music, industry that included railroads, lumber and mining (see figure 19). These patterns overlapped the segments, as did the color set, showing that independence and unique features also shared culture and many assets that, like a quilt, combined to make Tucker Culture. The color palette reflected the autumn deciduous forest, evening skies that define this elevated wilderness region. These three proposals each used all of these criteria, so that after the one was unanimously agreed upon, the others held potential for collateral applications for the brand, such as for event posters or shirt designs. 


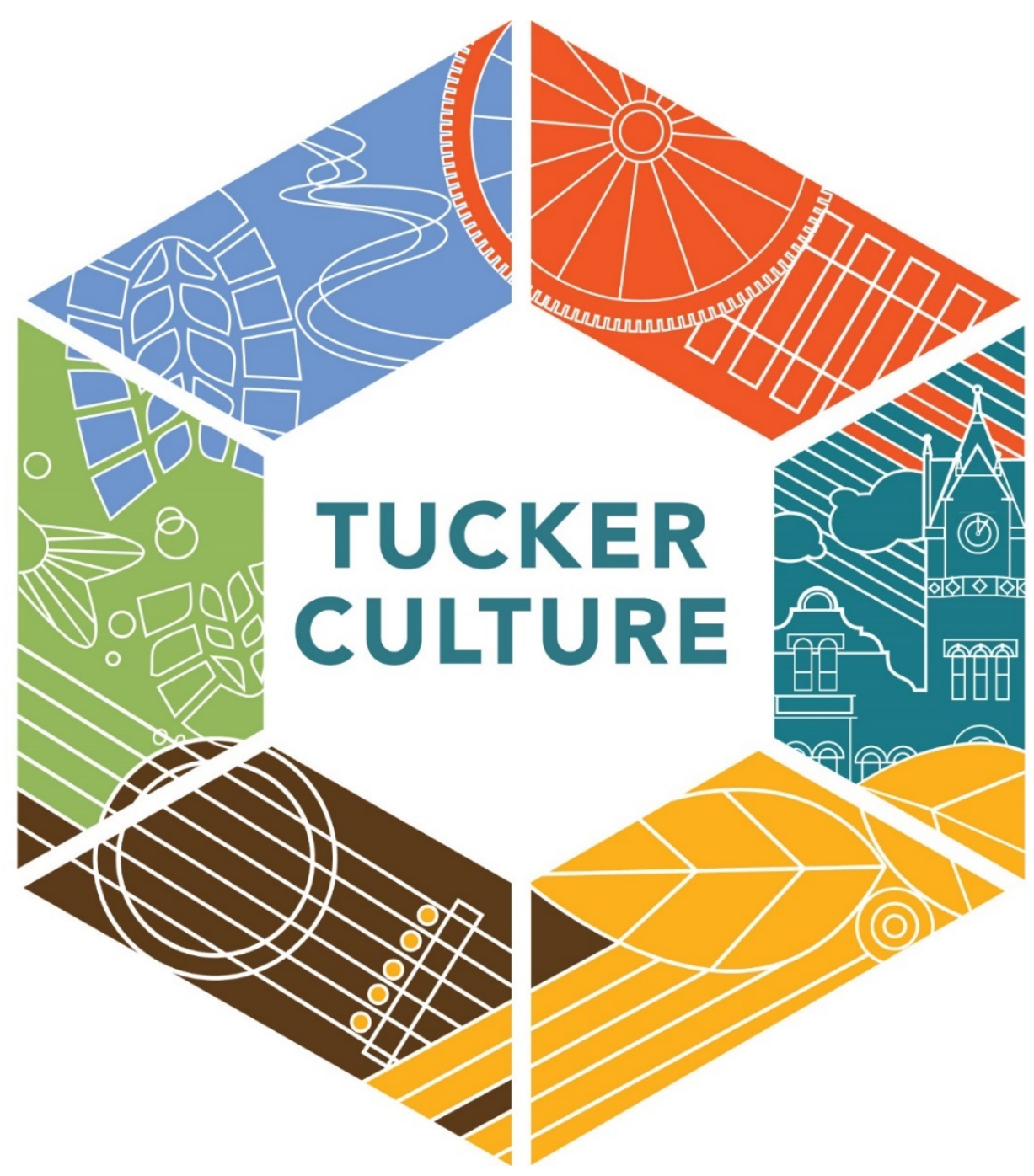

Figure 17 Tucker Culture

The new symbol set offered the ability for some icons to be selected over others to personalize the mark for individual towns or organizations in the Tucker Culture domain. Communities on the mountain might choose skiing and arts over the architectural depiction of the county courthouse, mining and fishing that dominate the valley preferences. The CDA and attendees chose the proposal by WVU graphic design senior, Brooke Deardorff. The CDA board and Americorps volunteer collected basic information for three brochures aimed at presenting the Arts/Cultural offerings, the Heritage/History offerings, and the Recreation/Nature/Adventure 
offerings. WVU student graphic designers created nine prototype brochures which were proposed, juried down to three by the CDA board and then one became the template for the set (see figure 20). The variations can be seen on the front of the original brochures—Arts, History and Recreation, that could now be vetted and completed. A kit has been developed for use at meetings to explain possibilities with a brand guide (see figure 21), signage ideas (see figure 22), buttons, and post cards for events that might bring people together for activities that involve storytelling, work parties and others to encourage community collaboration.

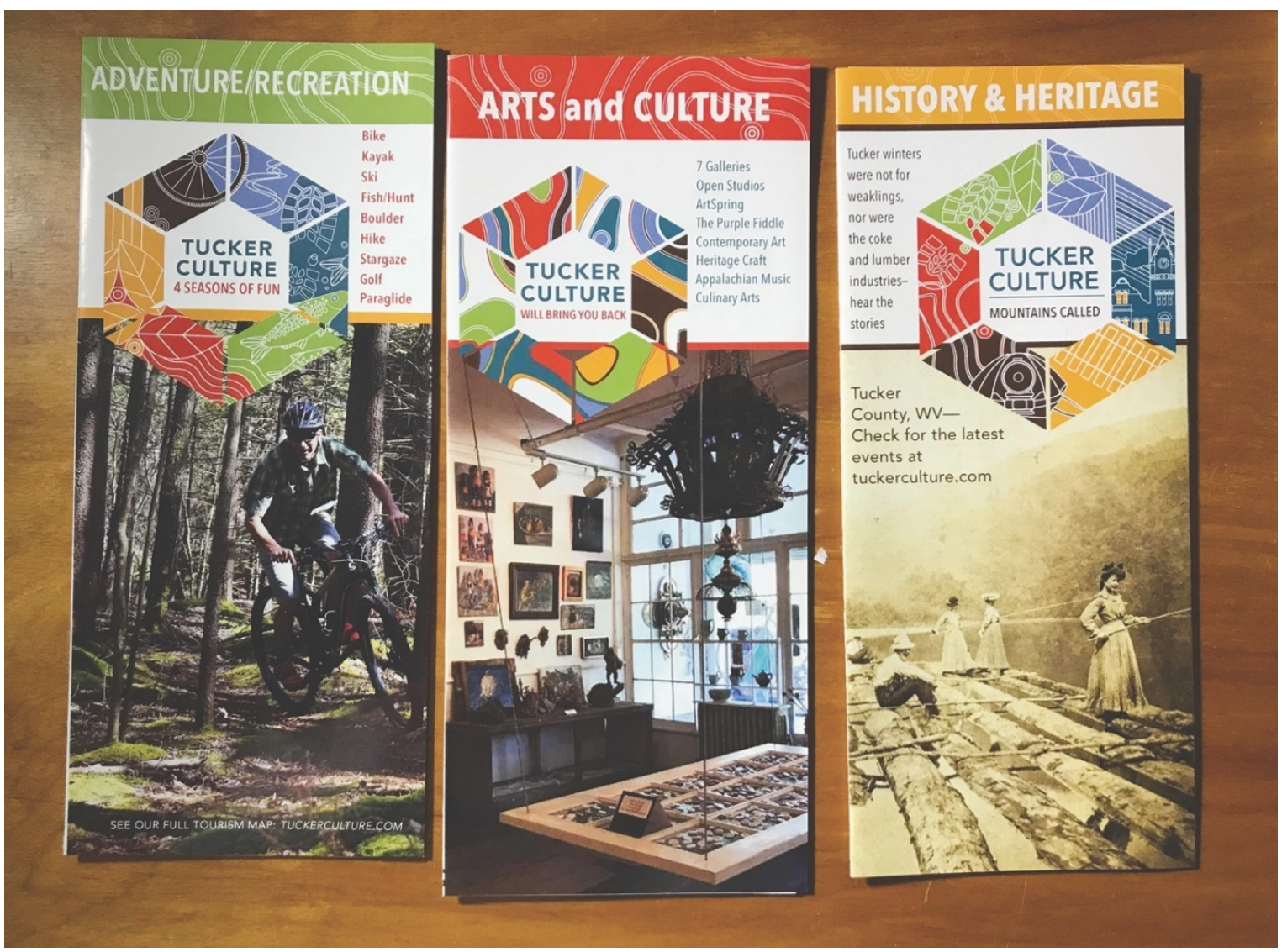

Figure 18 Tucker Culture Brochures 


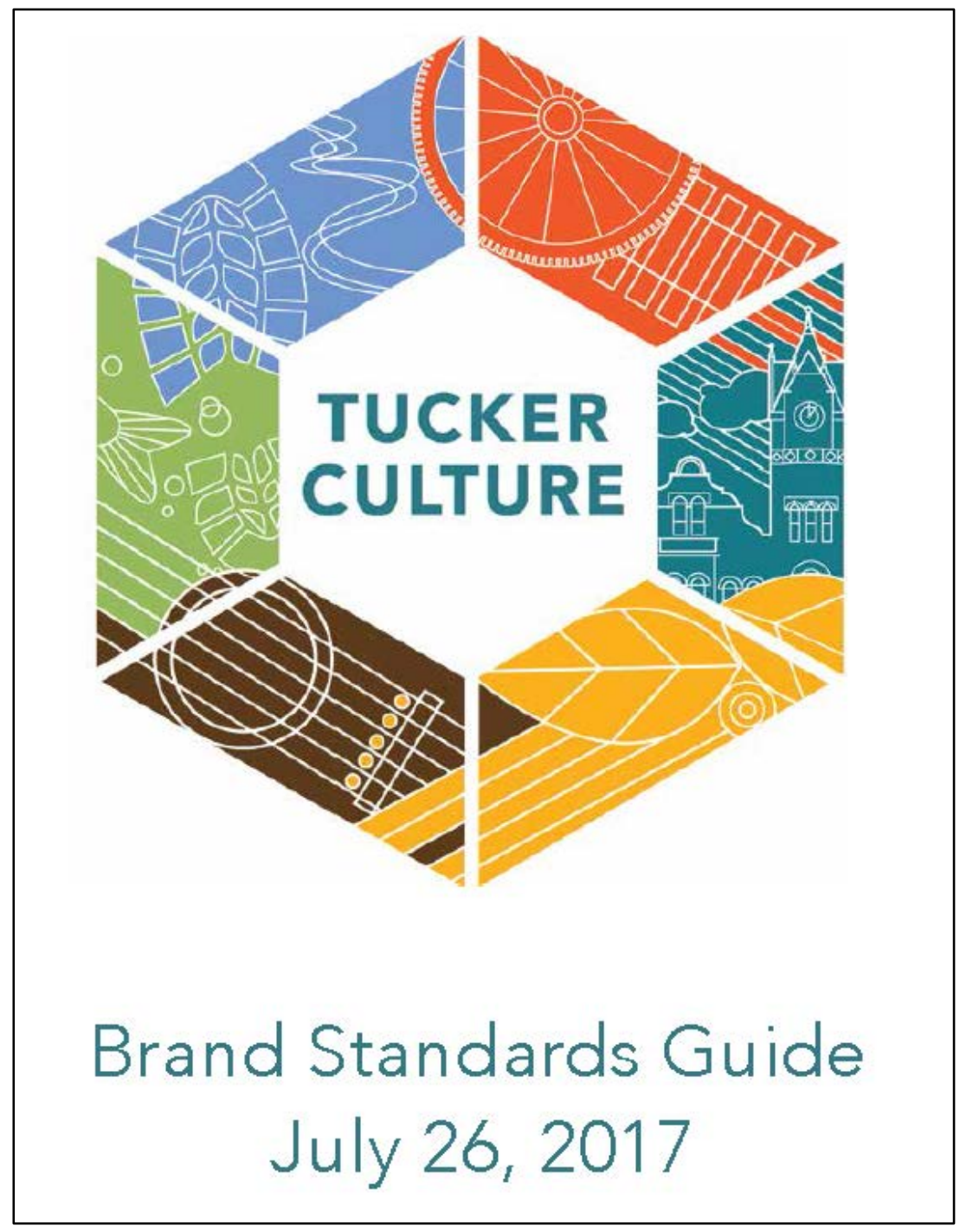

Figure 19 Tucker Culture Brand Standards Guide 


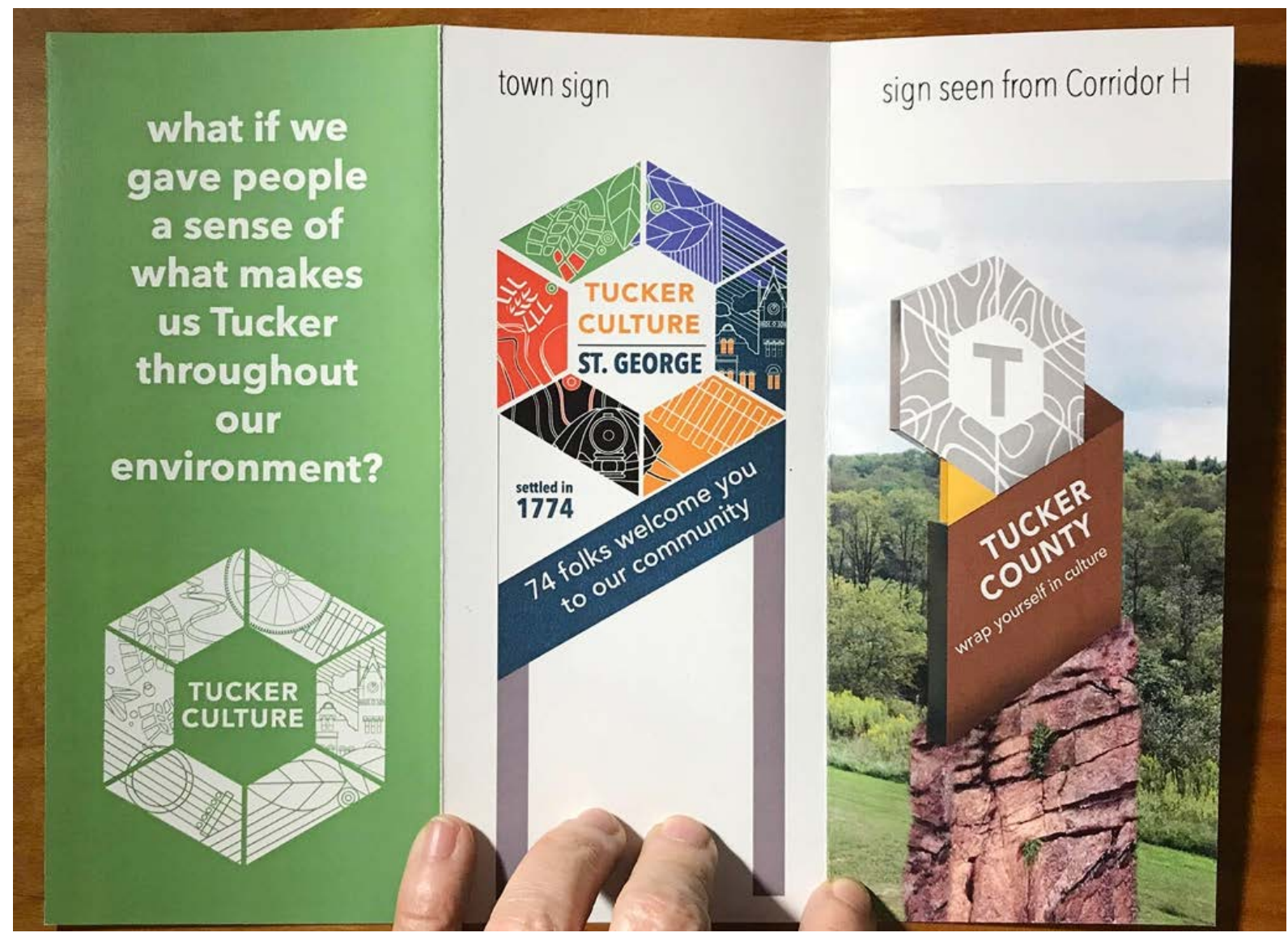

Figure 20 Tucker Culture Signage examples

\subsection{Discussion and Conclusion}

The transdisciplinary mixed methods planning and design activities described in this paper revealed significant opportunities for sustainable rural tourism in this rural destination. Quantitative and qualitative research outcomes from key informants, residents, and visitors were corroborated thus enhancing the validity of inferences through triangulation and formulating a “fuller field of vision” of the destination's opportunities and challenges and allowing for engagement with more people and diverse stakeholders (Hollinshead \& Jamal, 2007, p. 90; Molina-Azorin \& Font, 2016; Niglas, 2004; Stynes, 1991). Corroborated findings include the need for long term planning and managed growth; protecting community values; underutilized natural, cultural, and historic assets; the opportunity to develop nature-based, cultural, and 
historical attractions; and the need for a common vision and collective identity. This study makes a unique contribution to literature on sustainable tourism development by incorporating social design into a transdisciplinary rural tourism planning project. Since a researcher from a single field or discipline cannot fully address the complexities of a sustainable tourism project (Gunn, 1987; McGehee et al., 2013; Ritchie \& Inkari, 2006; Tribe, 1997), design faculty and students from Landscape Architecture and Graphic Design were engaged to use participatory design to further visualize and address key findings from the initial phases. GIS asset mapping revealed and spatially analyzed underutilized natural, cultural, and historic assets and the opportunity to better coordinate attractions and services and appeal to a more diverse market and visitor activity preferences. Participatory design workshops and mapping gaps in attractions, services, and amenities revealed opportunities for site design to optimize the visitor experience and increase the length of stay while enriching the cultural experience. The Landscape Architecture Extension Specialist brought the project into the studio environment to further develop plans and designs at the community and site scale in Canaan Valley, Davis and Thomas and begin to visualize the proposed changes. The graphic design team developed a connecting visual message to engage residents and visitors in Tucker County culture. Unique features of a shared cultural identity were revealed that, like a quilt, combine to make Tucker Culture. The design of a cultural identity provided a tangible outcome that was quickly translated into signage plans, brochures, buttons, event banners, and the centerpiece of the tuckerculture.com website.

The transdisciplinary approach provides a scaffolding of outputs to the community. As team members learned from the findings of fellow team members and actively participated within each's 'laboratory' what followed was a more profound understanding of the context for 
planning, and a more relevant and vigorous product, cultivating citizen control (Arnstein, 1969) of the planning process. Gibbs’ (2017) book Transdisciplinary Higher Education states that If higher education students are fortunate, they will experience more than disciplinary learning and be exposed to multidisciplinary learning (more than one discipline, with no integration), and interdisciplinary learning (between disciplines, with integration). However, all of these approaches remain confined to disciplines, excluding other ways of knowing. Transdisciplinary pushes the boundaries of these three approaches to include both higher education (mono, multi and inter-discipline) and larger society (government, industry, citizens and civil society). TD pedagogy helps students to learn to co-create, codisseminate and co-use transdisciplinary knowledge, which emerges from the iterative interactions between disciplines and the rest of the world.

Developing partnerships with communities for building capacity toward positive change is at the core of the land grant mission. The Kellogg Commission on the Future of State and Land-Grant Universities 1999 report titled Returning to our Roots: The Engaged Institution defines engagement as institutions that have redesigned their teaching, research, and extension and service functions to become even more sympathetically and productively involved with their communities, since despite the resources and expertise available on campuses, these institutions are not well organized to bring them to bear on local problems in a coherent way. A truly engaged university utilizing a transdisciplinary and mixed methods approach can help communities achieve the goals outlined by Molina-Azorin and Font (2016) of societal change, managing social desirability and advancing the concept of sustainable tourism through interdisciplinary cooperation which are also at the core of the land grant mission. 
Participatory planning and social design can maximize the advantages and minimize the disadvantages of developing sustainable rural tourism. Based on the results of the research and design activities the CDA adopted four tenets - Protect, Connect, Enhance, and Promote the Culture of Tucker County - and outlined its goals, objectives, and strategies in a performance agenda to guide the CDA's efforts as it works to achieve its vision of successfully implementing a community-led cultural tourism plan. Arbogast, Deng, and Maumbe (2017) developed a destination management framework in order to define a structure for the roles and responsibilities for destination marketing and management activities. The communities of Davis and Thomas formed planning commissions for the first time in 2017. This study confirms the need for greater understanding of transdisciplinary and mixed methods research, its special value and growing importance in sustainable tourism research, and its challenges and strengths for authors, editors, and communities (Molina-Azorin \& Font, 2016).

\subsection{Limitations}

As with many other tourism studies, this study is not without limitations. First, although a mailed questionnaire survey was used to target each household in the County, there is no control of who would fill the questionnaire. This may create possible survey response biases. Second, this study provided insight into the relationship between key informants, resident attitudes toward tourism, and visitor preferences in a rural destination. However, the results may be specific to the County and may not be generalized to other rural destinations. Further research is needed to better understand to what extent resident attitudes vary according to demographic variables. Arbogast, Deng, and Maumbe (2017) recommended additional analysis to further define the structure of the destination management network including the actors, links, density, and centrality as a logical next step in guiding the stakeholders of Tucker County, WV toward 
their vision for sustainable rural tourism. More research is required to better understand

destination management practices and challenges to sustainably managing and implementing the challenges and opportunities identified in this study.

\subsection{References}

About. (n.d.) Rural Studio, available at: from http://www.ruralstudio.org/

Arbogast, D., Deng, J. and Maumbe, K. (2017). DMOs and rural tourism: A stakeholder analysis the case of Tucker County, West Virginia. Sustainability, 9 (10), 1813.

Angotti, T., Doble, C. and Horrigan, P. Eds. (2012). Service-learning in design and planning: Educating at the boundaries, New Village Press, Oakland, CA.

Archer, B., and Fletcher, J. (1996). The economic impact of tourism in the Seychelles. Annals of Tourism Research, 23(1), 32-47.

Arnstein, S. R. (1969). A ladder of citizen participation. Journal of the American Institute of Planners. 35(4), 216-224.

Bahaire, T. and Elliott-White, M. (1999). The application of geographical information systems (GIS) in sustainable tourism planning: A review, Journal of Sustainable Tourism, 7(2), 159174.

Brown, D. (2002). Rural Tourism: An Annotated Bibliography. USDA Rural Information Center. Retrieved from http://www.nal.usda.gov/ric/ricpubs/rural_tourism.html

Belisle, F. J. and Hoy, D. R. (1980). The perceived impact of tourism by residents a case study in Santa Marta, Colombia, Annals of tourism research, 7(1), 83-101.

Boers, B. and Cottrell, S. (2007). Sustainable tourism infrastructure planning: A GIS-supported approach, Tourism Geographies, 9(1), 1-21.

Bose, M., Horrigan, P., Doble, C. and Shipp, S. C. (Eds.). (2014). Community matters: Servicelearning in engaged design and planning. Routledge.

Boyd, S. W. and Butler, R. W. (1996). Managing ecotourism: an opportunity spectrum approach, Tourism management, 17(8), 557-566.

Creswell, J. and Plano Clark, V. (2007). Designing and conducting mixed methods research, Sage, Thousand Oaks, CA.

Cole, S. (2014). Tourism and water: From stakeholders to rights holders, and what tourism businesses need to do, Journal of Sustainable Tourism, 22(1), 89-106. 
Cybernetics and Design: Conversations for Action. (November 1, 2015). Dubberly Design Office, Retrieved from http://www.dubberly.com/articles/cybernetics-and-design.html

Dean Runyan Associates. (2015). West Virginia Travel Impacts 2000-2014p. Retrieved from http://www.deanrunyan.com/doc_library/WVImp.pdf

Dillman, D., Smyth, J. and Christian, L. (2014). Internet, mail and mixed-mode surveys: The tailored design method (3rd ed.), Wiley, New Jersey.

Dolnicar, S. and Leisch, F. (2008). Selective marketing for environmentally sustainable tourism, Tourism Management, 29(4), 672-680.

Dye, A. S. and Shaw, S. L. (2007). A GIS-based spatial decision support system for tourists of Great Smoky Mountains National Park, Journal of Retailing and Consumer Services, 14(4), 269-278.

Elwood, S. (2006). Critical Issues in Participatory GIS: Deconstructions, Reconstructions, and New Research Directions, Transactions in GIS, 10, 693-708.

Fick, G.R. and J.R.B. Ritchie. (1991). Measuring service quality in the travel and tourism industry, Journal of Travel Research, Vol. 30, pp. 2-9.

Flora, C. B. (2004). “Community Dynamics and Social Capital”, Agroecosystems Analysis, pp. 93-107.

Frechtling, D. and Horvath, E. (1998). "Estimating the multiplier effects of tourism expenditures on a local economy through a regional input-output model”, Journal of Travel Research, 37(4), 324-332.

Gibbs, P. (Ed.). (2017). Transdisciplinary higher education: A theoretical basis revealed in practice, Springer.

Gunn, C. A. (1987). A perspective on the purpose and nature of tourism research methods, Wiley, New York.

Gunn, C. A. and Var, T. (2002) Tourism planning: Basics, concepts, cases (4th ed.). Routledge Taylor and Francis Group, New York.

Hassan, S. S. (2000). Determinants of market competitiveness in an environmentally sustainable tourism industry, Journal of Travel Research, 38(3), 239-245.

Hester, R. T. (2006). Design for ecological democracy, MIT Press, Cambridge, MA.

Hester, R. (2014). Skills that democratic designers will need: The place of participation, In Landscape Research Record, (2) Ming-Han Li, Ed. Keller: Texas. 
Hollinshead, K. and Jamal, T. B. (2007). Tourism and “The Third Ear”: further prospects for qualitative research, Tourism Analysis, 12(1-2), 85-129.

Horrigan, P. H., Bose, M., Doble, C. and Shipp, S. (2014). Community Matters: Service-learning in engaged design and planning. Routledge Earthscan, New York.

Inskeep, E. (1991). Tourism planning: An integrated and sustainable development approach. Van Nostrand Reinhold, New York.

Jones, S. (2005). Community-based ecotourism: The significance of social capital, Annals of Tourism Research, 32(2), 303-324.

Keogh, B. (1990). Public Participation in Community Tourism Planning, Annals of Tourism Research, 17, 449-465.

Kellogg Commission on the Future of State, Land-Grant Universities National Association of State Universities and Land-Grant Colleges (1999). Returning to our roots: The engaged institution (3). National Association of State Universities and Land-Grant Colleges, Office of Public Affairs.

Khoo-Lattimore, C., Mura, P. and Yung, R. (2017). The time has come: a systematic literature review of mixed methods research in tourism, Current Issues in Tourism, 4, 1-20.

Knollenberg, W. (2011), Stakeholders' attitudes towards sustainable tourism development in coastal communities. (Unpublished master's thesis). Retrieved from http://search.proquest.com.www.libproxy.wvu.edu/docview/889068285?pqorigsite $=$ summon .

Koc, E. and Boz, H. (2014). Triangulation in tourism research: A bibliometric study of top three tourism journals, Tourism Management Perspectives (12), 9-14.

Kuvan, Y. and Akan, P. (2012). Conflict and agreement in stakeholder attitudes: residents' and hotel managers' views of tourism impacts and forest-related tourism development, Journal of Sustainable Tourism 20(4), 571-584.

Lane, B. (2009). Thirty years of sustainable tourism: Drivers, progress, problems and the future, In S. Gossling, M.C. Hall, and D.B. Weaver (Eds.). Sustainable tourism futures: Perspectives on systems, restructuring, and innovations, Routledge, New York and London, 19-32.

Macbeth, J., Carson, D. and Northcote, J. (2004). Social capital, tourism and regional development: SPCC as a basis for innovation and sustainability, Current Issues in Tourism 7(6), 502-522.

McGehee, N. G., Boley, B. B., Hallo, J. C., McGee, J. A., Norman, W., Oh, C. O., and Goetcheus, C. (2013). Doing sustainability: An application of an inter-disciplinary and 
mixed-method approach to a regional sustainable tourism project, Journal of Sustainable Tourism 21(3), 355-375.

McGehee, N. G., Lee, S., O'Bannon, T. L. and Perdue, R. R. (2010). Tourism-related social capital and its relationship with other forms of capital: An exploratory study, Journal of Travel Research, 49(4), pp. 486-500.

Milman, A. and Pizam, A. (1988). Social impacts of tourism on central Florida, Annals of tourism Research, 15(2), 191-204.

Molina-Azorín, J. F. and Font, X. (2016). Mixed methods in sustainable tourism research: an analysis of prevalence, designs and application in JOST (2005-2014), Journal of Sustainable Tourism, 24(4), 549-573.

Murphy, L. (2001). Exploring social interactions of backpackers, Annals of tourism Research, 28(1), 50-67.

Nunkoo, R. and Ramkissoon, H. (2010). Small island urban tourism: a residents' perspective, Current Issues in Tourism, 13(1), 37-60.

Nunkoo, R. and Ramkissoon, H. (2011). Developing a community support model for tourism, Annals of Tourism Research, 38(3), 964-988.

Organization for Economic Co-operation and Development. (1994). Tourism strategies and rural development.

Onyx, J. and Bullen, P. (2000). Measuring social capital in five communities, The Journal of Applied Behavioral Science, 36(1), 23-42.

Oppermann, M. (2000). Tourism destination loyalty, Journal of Travel Research, 39(1), 78-84.

Park, D. B., Nunkoo, R. and Yoon, Y. S. (2015). Rural residents' attitudes to tourism and the moderating effects of social capital, Tourism Geographies, 17(1), 112-133.

Parsons. (2017). The New School. Retrieved from https://www.newschool.edu/parsons/designstrategies-school-sds/

Pilloton, E. (July 2010). Teaching design for change. Retrieved from https://www.ted.com/talks/emily_pilloton_teaching_design_for_change

Poslad, S., Laamanen, H., Malaka, R., Nick, A., Buckle, P. and Zipl, A. (2001). Crumpet: Creation of user-friendly mobile services personalized for tourism, Second International Conference on 3G Mobile Communication Technologies, 28 - 32. 
Ritchie, B. W., and Inkari, M. (2006). Host community attitudes toward tourism and cultural tourism development: the case of the Lewes District, Southern England. International Journal of Tourism Research, 8(1), 27-44.

Sanoff, H. (2010). Democratic design: Participation case studies in urban and small town environments. VDM Publishing, Saarbrücken, Germany.

Senate Bill 561. (2013). Tucker County Cultural District Authority. Retrieved from http://www.wvlegislature.gov/bill_status/bills_text.cfm?billdoc=sb561\%20intr.htmandyr=20 $\underline{13 a n d s e s s t y p e=R S a n d i=561}$

Sheldon, P. J. and Var, T. (1984). Resident attitudes to tourism in North Wales. Tourism Management. 5(1), 40-47.

Song, H., Dwyer, L., Li, G. and Cao, Z. (2012). Tourism economics research: A review and assessment. Annals of Tourism Research. 39(3), 1653-1682.

Stynes, D.J. (1991). Recreation and tourism monitoring systems: Conceptual and methodological issues. Proceedings 1991 Southeast Recreation Research Conference.

Thering, S. (2007). A practical theory based approach to action research in survivor communities. Journal of Extension. Retrieved from http://www.joe.org/joe/2007april/a3.php

Tribe, J. (1997). The indiscipline of tourism. Annals of Tourism Research. 24(3), 638-657.

U.S. Census Bureau. (2018). Quick Facts. Retrieved from https://www.census.gov/quickfacts/fact/table/tuckercountywestvirginia,US/PST045217

Urry, J. (2011). Climate change and society. Polity, London.

Wang, Y. and Pfister, R. E. (2008). Residents' attitudes toward tourism and perceived personal benefits in a rural community. Journal of Travel Research, 47(1), 84-93.

West Virginia University. (2017). West Virginia University Center for Service and Learning. Retrieved from https://service.wvu.edu/about 


\section{CHAPTER 5}

\section{Linking the effect of resident attitudes, social capital, and stakeholder engagement on rural tourism development in West Virginia.}

\subsection{Introduction}

As illustrated by this study, a mixed methods approach to sustainable rural tourism development and planning can provide more robust outcomes allowing for triangulation of data and drawing from multiple angles and research methods to focus on key variables for success in the multi-faceted destination management challenges facing rural destinations. This study has identified that more research is needed and a mixed methods approach can be effective at shedding light on the link between these variables and the keys to success for rural destinations to sustainably develop and manage tourism. The results of the study present evidence of triangulation of data for key variables for successful development and management of rural tourism, yet it is clear that the necessary resources for a primary organization to deploy a robust management strategy with the active participation of key stakeholders is a daunting task for rural destinations faced with capacity and funding shortfalls. This study has both theoretical and practical implications for the role of destination management organizations as backbone organizations and the role a land-grant university can play in a transdisciplinary approach to sustainable rural tourism development if a truly engaged university is to play a critical role in addressing these challenges. The following section discusses the findings of this study in the context of sustainable rural tourism development namely: stakeholder roles in destination management, the link between social capital, resident attitudes toward tourism, and support for tourism development, and transdisciplinary/mixed method approaches. 


\subsection{On key informants and destination management}

Findings from this study revealed that although Presenza, Sheehan, and Ritchie (2005) suggest a DMO should play a dual marketing and management role, in Tucker County a clear separation of marketing and management roles and responsibilities for the Convention and Visitors Bureau and Cultural District Authority was identified. Destination management challenges included maintaining authenticity and sense of place; staffing and quality personnel; pursuing target markets that minimize negative tourism impact and appreciate the uniqueness of the region; coordination, cooperation, and partnerships between businesspersons, local leadership, and rural tourism entrepreneurs; respect for local residents; positive economic impact for the community; and economic diversification. While the destination is fortunate to have organizations and businesses committed to sustainable development of the destination, a destination management framework was lacking, thus the authors developed a perceived destination management framework based on the outcomes of the stakeholder analysis in order to define a structure for the roles and responsibilities for destination marketing and management activities. Follow-up research is suggested to determine whether identified critical stakeholders have existing relationships with the other members of the proposed network and for identifying those organizational stakeholders who should lead in establishing and coordinating the activity of tourism stakeholder networks.

\subsection{On the effect of social capital and resident attitudes toward tourism on support for tourism development and differences among groups}

Finding from this study revealed that establishing a common vision and participation in community organizations can be key factors in predicting support for tourism development helping to identify which groups of people are more concerned or opposed to tourism within the community. This study took a deeper assessment of the broader citizen network in order 
to identify concerns and variables that affect variations in the level and content of development to create tourism development plans and priorities that reflect local concerns and reinforce norms. While this study confirms the finding of other studies that long term planning and protection of community values are essential for sustainable rural tourism development, this study revealed the need to consider elements of social capital including a common vision and participation in local organizations and informal social groups in order to secure resident support for tourism development. Incorporating residents involved in local organizations and informal social groups in the tourism planning process can help in establishing a common vision for tourism and create a tourism development plan that protects community values and includes mechanisms to manage growth, reduce negative environmental and social impacts, and maintain the special qualities of rural destinations that create a high quality of life for local residents and attract visitors. This study further analyzed differences in group, stake, or power to better understand which groups to potentially target for inclusion in the tourism planning process which included non-profit organizations, short term residents, male residents, and non-tourism related business owners and employees.

\subsection{On mixed methods and transdisciplinary design}

The transdisciplinary mixed methods study corroborated findings of the destination's opportunities and challenges through triangulation and allowed for engagement with more people and diverse stakeholders. Corroborated findings in the initial phases of the study conducted with mixed methods and a transdisciplinary team included the need for long term planning and managed growth; protecting community values; underutilized natural, cultural, and historic assets; the opportunity to develop nature-based, cultural, and historical attractions; and 
the need for a common vision and collective identity. This study makes a unique contribution to literature on mixed methods and transdisciplinary sustainable tourism development by incorporating social design into a transdisciplinary rural tourism planning project. Through a participatory process, plans and designs were developed at the community and site scale in order to visualize the proposed changes; and, a connecting visual message was created to engage residents and visitors in Tucker County culture. Unique features of a shared cultural identity were revealed that, like a quilt, combine to make Tucker Culture. The transdisciplinary approach provided a scaffolding of outputs to the community. This study confirms the need for greater understanding of transdisciplinary and mixed methods research, its special value and growing importance in sustainable tourism research, and its challenges and strengths for authors, editors, and communities (Molina-Azorin \& Font, 2016).

\subsection{Conclusion}

In order to maximize the positive impacts while minimizing the negative impacts of tourism development on a destination, it is necessary to understand attitudes held by local residents and other stakeholders toward tourism. Also, it is important to engage and empower local residents in tourism planning and development. Participative tourism planning has been promoted by scholars as a way to avoid the negative impacts of tourism and offset some unintended impacts of tourism development such as anger, apathy or mistrust of tourists by locals (Gursoy, Jurowski \& Uysal, 2002). In tourism, the most successful destinations have found ways to engage in collective decision-making about the goals of the community and how they can be met through the development of a cohesive tourism product (McGehee et. al, 2010). The findings of this study contribute to the growing body of literature on participatory planning for sustainable rural tourism development and provide practical implications for the destination, 
yet overcoming the challenges identified in this study and capitalizing on the opportunities will continue to be a considerable challenge for the destination in the foreseeable future.

The concept of "collective impact” introduced in the winter 2011 issue of Stanford Social Innovation Review can be applied as a framework for acting on the findings of this study. The Tucker County, WV Cultural District Authority is well positioned to serve a critical role in the destination as a backbone organization for sustainable rural tourism development and management. According to collective impact, backbone organizations serve six essential functions: providing overall strategic direction, facilitating dialogue between partners, managing data collection and analysis, handling communications, coordinating community outreach, and mobilizing funding. Creating and managing collective impact requires a separate organization and staff with a very specific set of skills to serve as the backbone for the entire initiative. Coordinating large groups in a collective impact initiative takes time and resources, and too often, the expectation that collaboration can occur without a supporting infrastructure is one of the most frequent reasons why it fails. The highly important perceived neutrality of the organization, and the ability to mobilize stakeholders are also key components of a backbone organization. Backbone organizations also face two distinct challenges: leadership and funding. No collective impact effort can survive unless the backbone organization is led by an executive possessing strong adaptive leadership skills; and, the ability to mobilize people without imposing a predetermined agenda or taking credit for success. Backbone organizations must maintain a delicate balance. Backbone organizations rely on the support of a stakeholder network. Although activities of the network can occur separately, they must communicate and be coordinated with each other in cascading levels of linked collaboration. Effective coordination by the backbone can create aligned and coordinated action among hundreds of stakeholders that 
simultaneously tackle many different dimensions of a complex issue, like rural tourism development.

These backbone organizations require external support. Universities can play a critical role in serving as a backbone organization and supporting the work of local backbone organizations through transdisciplinary partnerships and participatory research. According to University of Minnesota Tourism Center Director, Cynthia Messer, University Centers and land-grant institutions can strengthen transdisciplinary through joint or shared research, student engagement and bringing community-based outreach experiences to enhance traditional classroom education (C. Messer, personal communication, June 17, 2017). Gibbs’ (2017) book Transdisciplinary Higher Education states that transdisciplinary pushes the boundaries to include both higher education (mono, multi and inter-discipline) and larger society (government, industry, citizens and civil society). TD pedagogy helps students to learn to co-create, co-disseminate and co-use transdisciplinary knowledge, which emerges from the iterative interactions between disciplines and the rest of the world. Through increased levels of trust, blurring of disciplinary boundaries and escalated valuing of each other's knowledge and perspectives, transdisciplinary learners become a community of learners working for a common cause. Participatory research combines research, education, and action. It is an educational process since the researcher and the participants jointly analyze and learn about the causes and possible solutions for the problem addressed. It is an action oriented research activity since the findings and solutions are implemented into practice (Kemmis, McTaggart, \& Nixon, 2013).

Achieving successful collaboration, partnerships, and collective impact in rural destinations is a tremendous challenge. Land-grant universities and engaged university faculty can play a critical role and can support the backbone organization while building the capacity and 
leadership of the local organizations to assume the responsibility of the backbone organization and establish the leadership, coordination, and funding necessary for success. Transdisciplinary partnerships and participatory action research are essential to engaging community stakeholders as equal partners in analyzing, identifying, and addressing solutions to the myriad of complex issues they face in developing a quality of life and creating sustainable rural tourism economies.

In 2016, the Tucker County, WV CDA adopted four tenets - Protect, Connect, Enhance, and Promote the Culture of Tucker County - and outlined its goals, objectives, and strategies in a performance agenda to guide the CDA's efforts as it works to achieve its vision of successfully implementing a community-led cultural tourism plan. It is the authors hope that the results of this study can help to guide the destination toward its goal to adopt a cultural tourism vision and make informed, community-based decisions with input and participation from community stakeholders and residents in an attempt to lead tourism growth, while preserving the County's culture, heritage, and authenticity.

\subsection{Policy Implications}

This study has important policy implications for West Virginia that could be addressed through the deployment of resources to support strengthening local capacity and provide land grant university support. While this study has identified key variables for success in the multifaceted destination management challenges facing rural destinations, examples of what other states are doing to foster participatory planning and structure resources to support backbone organizations at the local and state level can also provide insight into what could be done in West Virginia and other states to implement the findings of this study and take action to support sustainable rural tourism development. 
Pennsylvania is an example of state that allocates resources and provides structures support within state government to build local capacity and deploy programs to support sustainable rural tourism development. According to the Pennsylvania Conservation Landscape Initiatives Report (2010), in Pennsylvania the landscape is changing, communities face economic challenges, and natural resources are under new threats. Rampant resource extraction to fuel an industrializing nation put natural resources on the brink of disaster and communities floundering when industry left town. Thankfully, conservation leaders envisioned a future Pennsylvania defined by its natural beauty and worked to re-establish its heritage by setting aside lands for public enjoyment. Today, 60 percent of the landscape is forested. Wild and natural areas capture the beauty of the past and serve as the foundation for outstanding recreation, scenic beauty, nature-based tourism and vibrant communities. The state's natural resource agency and primary conservation and recreation funding source for communities is the Department of Conservation and Natural Resources (DCNR) which saw the need to refocus its expertise to help address these new challenges. Instead of working exclusively within its park and forest boundaries or within a specific community, the agency broadened its approach to defined regions, or conservation landscapes.

In addition to the DCNR, the Pennsylvania Department of Community and Economic Development provides funding for business expansion, community projects, and site revitalization (Pennsylvania Department of Community and Economic Development, n.d.). With funding from the state's realty transfer tax, the Keystone Recreation, Park, and Conservation Fund supports construction and installation of trails, community and state park facilities, and historic preservation projects helping the state become a national leader in trails (Keystone Fund, n.d.). On November 15, 2018, Governor Tom Wolf announced an investment of $\$ 50$ million for 
280 projects across Pennsylvania that will create new recreational opportunities, conserve natural resources, and help revitalize local communities helping to bring opportunities for outdoor recreation closer to home and attract families, visitors, and businesses that provide jobs to communities (Pennsylvania Pressroom, 2018). Finding the Green is a guide to state funding opportunities for conservation, recreation, and preservation projects from the PA Department of Agriculture, Department of Community and Economic Development, Department of Conservation and Natural Resources, Department of Environmental Protection, Department of Transportation, Fish \& Boat Commission, historical \& Museum Commission, and Infrastructure Investment Authority (Finding the Green, 2017).

The Pennsylvania DCNR believed that strategic investment around conservation, community revitalization and recreational projects within a landscape could profoundly affect local communities and help protect important natural assets. These Conservation Landscape Initiatives are driven by a partnership approach to getting work done at the regional level. By getting community leaders, other state agencies, local governments, philanthropies and nonprofits all engaged around a common goal - motivated by a sense of place - it was much easier to tackle effective land use planning, investment, citizen involvement and revitalization. The Conservation Landscapes Initiative is a nontraditional strategy for government to target reinvestment and engage with communities for the benefit of resource conservation and community revitalization.

The key ingredients that have helped define the conservation landscapes for the Pennsylvania Department of Conservation and Natural Resources include:

- Sense of Place: These regions are based on a shared landscape and are not defined by political boundaries. 
- Readiness: Communities are ready to participate in a region-wide effort often because of threats or opportunities such as changes in the economic base, declining population or urban sprawl.

- Strategic Investments: State agencies with regional and statewide partners provide highlevel leadership, financial support and technical assistance.

- DCNR interests and lands: The presence of state parks, state forests or significant recreational investments in the region provides the foundation for the landscape as well as staff who can help guide the initiative.

As each Conservation Landscape Initiative (CLI) has gained momentum and recognition, citizens have become more engaged in the work. In the Lehigh Valley CLI, environmental advisory committees, which are small groups of appointed citizens, advise the municipal planning commission, park and recreation board, and elected officials on the protection and management of natural resources. DCNR has also provided mini-grants to nonprofits that allow them to take action on issues their communities deem most important.

The Pennsylvania Wilds is one of the seven Conservation Landscapes in Pennsylvania. The land mass of the northcentral Pennsylvania landscape covers 25 percent of the state and holds about 4 percent of its population. The vision of the Pennsylvania Wilds Conservation Landscape is to help revitalize rural communities through sustainable tourism development -- all while inspiring a stewardship ethic in residents and visitors. Since 2003, the DCNR has invested over \$135 million in the Pennsylvania Wilds. In addition, the Pennsylvania Department of Community and Economic Development provides funding for a Small Business Ombudsman in the Pennsylvania Wilds to assist area businesses. Since being launched in 2003, the effort has had a significant and positive impact on both the businesses and communities in the region and 
partnerships have been a hallmark of this success. The Pennsylvania Wilds has been guided by a group of 40 organizations representing federal, state, and county government; tourism and cultural interests; education, economic development and the private sector. For more than a decade, the partners in the area have worked to: ensure stewardship of the public lands and character of the region's communities, support and grow private businesses such as accommodations, services, and locally-made products, promote the renewal of the region's communities and appropriate community planning, and invest in public infrastructure to enhance the visitor experience (Pennsylvania Wilds Conservation Landscape, n.d.).

The partners are coordinated by the PA Wilds Center. In 2016 the non-profit PA Wilds Center was established with the mission of integrating conservation and economic development in a way that strengthens and inspires communities in the Pennsylvania WILDS. The Pennsylvania Wilds Center for Entrepreneurship (PA Wilds Center) is the coordinating entity for the PA Wilds Conservation Landscape and operates all of the PA Wilds programs for businesses and communities. The Center includes a staff of seven including an Executive Director, Managing Director, and Communications Director. The Center's guiding strategy includes bringing visitors to the region to boost local economies, attracting investment and improving quality of life, unifying partners around the PA Wilds work, delivering programs and services to their businesses and communities, and stewarding the region's public lands and natural assets, rural lifestyle, and unique community character while sustaining the organization and vision for future generations The Center's work is sustained through program fees, philanthropic giving, government grants, and entrepreneurial activities related to the Pennsylvania Wilds brand. The Wilds Cooperative of Pennsylvania (WCO) is the core business development program of the PA Wilds Center. One of rural Pennsylvania's largest networks of creative entrepreneurs, more than 
275 businesses, artisans and producers currently participate. The PA Wilds Conservation Shop is the network of brick and mortar and online gift shops selling locally-made, value-added or PA Wilds branded products from the WCO (PA Wilds Center, 2018).

Minnesota provides an excellent example of the state's land grant university taking a leadership role as a backbone organization and leveraging its resources to support sustainable rural tourism development and build the capacity of local backbone organizations throughout the state. The University of Minnesota Tourism Center was established in 1987 to support Minnesota's tourism industry. The Center is housed in the University of Minnesota's Extension Service which has the mission of discovering science-based solutions, delivering practical education, and engaging Minnesotans to build a better future. Over the years, the Tourism Center has built a national reputation for educational materials, programs and research. The $\$ 15$ billion tourism industry in Minnesota relies on research and education from the University of Minnesota Tourism Center. The Center focuses on research, education, and engagement maintaining a close relationship with the industry and communities in Minnesota. Tourism Center affiliates are University faculty and professional staff in multiple disciplines across the University of Minnesota system whose academic areas of interest align with Minnesota's tourism industry and the mission of the Tourism Center. In cooperation with the Center, these affiliates engage undergraduate and graduate students in projects related to the tourism industry (University of Minnesota Extension, 2019).

The University of Minnesota Tourism Center’s operational funding comes from Extension, with additional funding from fees and grants. The Tourism Center also receives program and research funding support from the Carlson Travel, Tourism and Hospitality Endowed Chair. The Carlson Chair was created with an initial gift from Curt Carlson, matched 
by gifts from more than 130 industry supporters. The University of Minnesota Tourism Center maintains a 22-person industry advisory committee, along with strong working relationships with Explore Minnesota Tourism (the state agency) and key industry associations. The state tourism director has a permanent seat on the Center's advisory, and the Tourism Center's director holds a similar appointment on the Governor's Tourism Council. No direct funding is received from the state, however, the Tourism Center and Explore Minnesota conduct collaborative research, support each other's programming efforts to build local capacity and tourism initiatives (C. Messer, personal communication, March 15, 2018).

Oregon provides another example of land-grant University and state government support that is providing critical resources and building local capacity for sustainable rural tourism development. The Oregon Sea Grant program for Sustainable Coastal Tourism \& Outdoor Recreation provides applied research for communities and businesses, direct business training, and advising/consultations with community organizations, businesses and individuals. They work with convention and visitor bureaus, hotels, tour operators, fishing guides, conservation organizations, agencies, and non-profit organizations. OSU Extension faculty work with business people, growers, foresters, youth, and community leaders. Extension educators consult with scientists at Oregon State University, where they focus their research on the real issues important to local people. Results from that research circle back to the community through Extension programs. Knowledge grows from this cycle of reaching out and engaging the people who use it (Oregon State University, n.d.).

In addition to the land-grant University and Extension's role in sustainable tourism in Oregon, the state fosters regional partnerships to support sustainable tourism. Oregon's South Coast Regional Tourism network's mission is to collaborate to enhance economic development 
through sustainable tourism through a region-wide cross-sector of independent individuals and organizations. They focus on leveraging relationships, opportunities and dollars and work to create consensus around priorities that will set up other tourism organization for success collaborating with regional tourism organizations in a strategic direction that will lay the groundwork to develop the Southern Oregon Coast into a destination (Oregon South Coast Regional Tourism Network, n.d.).

Travel Oregon is the state’s tourism office. In addition to destination marketing resources, Travel Oregon offers a wide variety of education and training programs for members of the travel and tourism industry. Travel Oregon supports seven Regional Destination Management Organizations (RDMOs) recognized by Travel Oregon can develop and submit regional plan proposals for use of state dollars. By leveraging state dollars along with private and public resources, the RDMO’s work with Travel Oregon to bolster Oregon’s tourism economy. Travel Oregon provides planning, training and coaching to help communities in Oregon create a shared vision to advance and manage tourism in their region. Destination development programming includes Oregon Tourism Studios, product development initiatives, and destination management services.

To help communities across the state increase their economic vibrancy by improving their appeal as visitor destinations, Travel Oregon offers the Oregon Tourism Studios which provides a team to help communities cultivate regional visions; identify strategies to harness the power of tourism; and develop unique experiences in culinary and agritourism, outdoor recreation, bicycle tourism, cultural heritage tourism and more. Through this process, Travel Oregon helps leaders build resilient regional networks and leadership skills to manage sustainable tourism development. Graduating communities of the Rural Tourism Studio are 
eligible to apply for up to $\$ 10,000$ in matching grant funds. In addition to the Rural Tourism Studio, Travel Oregon also offers the Destination Management Studio and the Tourism Experience Studio to help build local capacity to plan and develop sustainable rural tourism (Travel Oregon, 2019).

The states of Pennsylvania, Minnesota, and Oregon have strategically aligned resources and allocated funding to support sustainable rural tourism development by allocating resource and building the capacity of local DMOs, state government agencies, and land-grant Universities to serve as backbone organizations and play a prominent role in sustainably developing and managing rural tourism and capitalizing on opportunities while overcoming challenges and managing impacts. While additional research is needed to further identify the keys to success in these and other rural destinations, these states serve as good models for West Virginia and other states seeking to allocate resources and foster collaboration through a land-grant University, state government, and local DMOS’s to sustainably manage and develop rural tourism.

\subsection{Limitations}

While this study has revealed important implications for rural destinations, this study is not without its limitations. As noted in previous chapters, the results may be specific to the County and may not be generalized to other rural destinations. While this study revealed a clear delineation of destination marketing and management activities and a perceived destination management framework, additional research to apply the destination management model to other rural destinations should be conducted in order to determine if this delineation is consistent in other destinations or if marketing and management activities are combined activities of a rural DMO as suggested by the literature. Additional research is necessary to determine whether stakeholder roles and activities and destination opportunities and challenges are consistent or 
change over time as this and other rural destinations continue through different stages of the Tourism Lifecycle (Butler, 1980).

Further research is needed to better understand to what extent social capital, resident attitudes toward tourism, and support for tourism vary according to demographic variables. While this study provided a more multi-dimensional approach by including social capital in analysis of factors predicting support for tourism development, future studies should incorporate the perspective of visitors and residents interaction with visitors to further develop a more multi-dimensional approach. More research is required to better understand destination management practices and challenges to sustainably managing and implementing the challenges and opportunities identified in this study.

This study is a case study of a rural destination in West Virginia and thus the author cautions against generalizing to other rural destinations. Further studies in other rural destinations are recommended to continue to identify keys to success for sustainable rural tourism development. Additional research should be conducted in rural destinations in other states and countries to apply these methods and models and further test the findings of this study to determine if these findings are consistent across rural destinations or unique to this destination. More research is needed to determine if a mixed methods approach can be effective at shedding light on the link between these variables and the keys to success for rural destinations to sustainably develop and manage tourism.

\subsection{References}

Butler, R. W. (1980). The concept of a tourist area cycle of evolution: Implications for management of resources. Canadian Geographer, 24, 5-12.

Collective Impact (2011). Stanford social innovation review. Retrieved from https://ssir.org/articles/entry/collective_impact 
Conservation Landscapes Initiative (June, 2010). Pennsylvania Conservation Landscapes Initiative Report. Retrieved from http://www.docs.dcnr.pa.gov/cs/groups/public/documents/document/d_001835.pdf

DCNR. (n.d) Pennsylvania Wilds Conservation Landscape Retrieved from https://www.dcnr.pa.gov/Communities/ConservationLandscapes/PennsylvaniaWilds/Pages/d efault.aspx.

Finding the Green. (2017). A guide to state funding opportunities for conservation, recreation, and preservation projects. Retrieved from http://www.docs.dcnr.pa.gov/cs/groups/public/documents/document/dcnr_20028890.pdf

Gibbs, P. (Ed.). (2017). Transdisciplinary higher education: A theoretical basis revealed in practice. Gewerbestrasse, Switzerland: Springer.

Gursoy, D., Jurowski, C., \& Uysal, M. (2002). Resident attitudes: A structural modeling approach. Annals of tourism research, 29(1), 79-105.

Kemmis, S., McTaggart, R., \& Nixon, R. (2013). The action research planner: Doing critical participatory action research. Springer Science \& Business Media.

Keystone Recreation, Park \& Conservation Fund. (n.d.). Legacy of Success. Retrieved from https://keystonefund.org/legacy-of-success/

McGehee, N. G., Lee, S., O'Bannon, T. L., \& Perdue, R. R. (2010). Tourism-related social capital and its relationship with other forms of capital: An exploratory study. Journal of Travel Research, 49(4), 486-500.

Oregon South Coast Regional Tourism Network. (n.d.). Retrieved from https://www.oscrtn.com/about.html

Oregon State University. (n.d.). Extension’s Sustainable Tourism Program. Retrieved from http://tourism.oregonstate.edu/

PA Wilds Center for Entrepreneurship (2018). PA Wilds Center for Entrepreneurship strategic plan 2018-2020. Retrieved from http://www.pawildscenter.org/wpcontent/uploads/2018/05/PAWildsCenter-StrategicPlan.pdf

Pennsylvania Department of Community and Economic Development. (n.d). Programs and Funding. Retrieved from https://dced.pa.gov/programs-funding/

Pennsylvania Pressroom. (November 15, 2018). Wolf Administration Announces $\$ 50$ Million Investment to Improve Recreation, Community Revitalization across Pennsylvania. Retrieved from https://www.media.pa.gov/Pages/DCNR_details.aspx?newsid=530 
Travel Oregon. (2019). Industry Resources. Retrieved from http://industry.traveloregon.com/industry-resources/

University of Minnesota Extension. (2019). Tourism. Retrieved from https://extension.umn.edu/community-development/tourism 
Appendix E Tucker County Stakeholder Interview Questions

1. Name, Title, Organization you work for.

2. How long have you lived in Tucker County?

3. How long have you been in this role, have you had former roles in TC?

4. Describe Tucker County. How do you feel about being a part of this community and your role in it?

5. How would you characterize tourism in Tucker County today?

6. How has tourism in Tucker County changed over the past 20 years? Describe the changes

7. What is your vision for tourism in Tucker County?

8. What role does your organization play in tourism development, management, or marketing? Current activities, programs, projects

9. Would you like your organization to play more of a role or a different role in tourism development, management, or marketing?

10. Describe some ways that your organization partners with other organizations/agencies/individuals?

11. How does the community work together to develop and promote tourism?

12. Is there a shared vision for tourism in Tucker County? If so, describe it.

13. How does tourism reflect a unique sense of place or authenticity in Tucker County?

14. Is it important that community values are protected when tourism is developed? If so, what values?

15. How would you define the culture of Tucker County?

16. What type of tourists would you consider to be the target markets?

17. Are there state, local, or national trends that are affecting tourism in Tucker County?

18. Is tourism in Tucker County marketed effectively? Why or why not?

19. What benefits has Tucker County seen from tourism?

20. What challenges has Tucker County seen from tourism?

21. Describe any negative impacts from tourism in TC? Do you foresee any in future?

22. What is the biggest challenge for TC?

23. What is the biggest opportunity for Tucker County?

24. What additional tourism attractions or services does Tucker County need?

25. What is the attitude of local residents toward tourism?

26. How has tourism affected the quality of life for residents in Tucker County?

27. Do residents get along?

28. What is the role of local gov't in tourism - how has it changed?

29. What role does the public play in tourism decision making?

30. What role does private business play in tourism decision making?

31. What role does tourism play in the overall economy of Tucker County?

32. Why did you choose Tucker County for your tourism business or operation?

33. Describe your experience starting and operating a tourism business in Tucker County.

34. Has tourism produced the outcomes that the community (or you) hoped for?

35. How do you measure the success of tourism in Tucker County?

36. How would you define sustainable tourism in TC?

37. What do you love about TC?

38. One final statement about tourism in TC ----

39. Other comments about tourism in TC that we have not addressed? 
Appendix F: Survey Instrument

Dear Tucker County Resident:

This is your last chance to help shape the future of tourism in Tucker County. If you already completed the questionnaire from a previous mailing we thank you for your participation and ask that you do not complete it a second time. Feel free to pass it on to another resident of Tucker County and encourage them to participate.

We are writing once again to ask your help in understanding residents' attitudes and opinions toward tourism in Tucker County. We ask that you please take a moment to complete the enclosed survey and return the completed questionnaire in the postage paid return envelope by November 23, 2016. This is a formal study being conducted by West Virginia University for the Tucker County Cultural District Authority. The study is a component of my dissertation research on rural tourism development so I very much appreciate your participation. The study was funded by the Benedum Foundation with the following objectives:

1. Better understand residents' attitudes about tourism in this region.

2. Determine tourism development priorities for Tucker County over the next 1-5 years.

3. Determine how local leadership can learn about and respond to public opinions and develop tourism in a manner that will improve the quality of life in Tucker County

It's our understanding that you are a resident of this region. This survey is open to anyone residing either full or part-time in Tucker County 18 years of age or older.

Your participation in this survey is voluntary and you can quit at any time. However, you can help us very much by taking a few minutes to respond. You do not have to answer all of the questions, but any information you provide will contribute to the project's success. This study was approved by West Virginia University's Institutional Review Board.

All information collected will be kept strictly confidential. Information you provide is anonymous and only summaries will be reported in which an individual's answers will not be identified. Your name will never be connected to your answers in any way.

If you complete the survey you will be entered into a drawing to win a summer 2016 family float trip with Blackwater Outdoor Center, 2 tickets to a West Virginia Black Bears baseball game, or two tickets to a WVU Men's Basketball game. You must complete the survey and enter contact information at the end of the survey to participate in the prize drawing so that we can contact you if you are the winner.

If you have any further questions, please feel free to contact Doug Arbogast at doug.arbogast@mail.wvu.edu or 304-293-8686. Your contribution to this study is greatly appreciated and will be a great benefit to this region.

Sincerely,

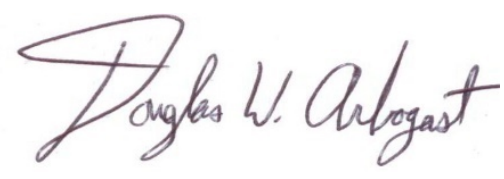

Doug Arbogast

West Virginia University

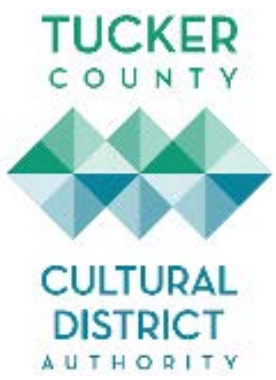


Ph.D. Candidate

Recreation, Parks, and Tourism Resources Program

Questionnaire \# 
Please identify the community you currently reside in or live closest to either full-time or part-time in Tucker County. Please select only one community.
Thomas
Davis
Canaan Valley
St. George
Hambleton
Hendricks
Parsons
Red Creek

Other

\section{Thoughts and Feelings about Tourism in Tucker County}

Please identify your thoughts and feelings toward tourism in Tucker County by indicating how much you agree or disagree with each statement by circling the number that best represents your answer.

\begin{tabular}{|c|c|c|c|c|}
\hline $\begin{array}{c}\text { Strongly } \\
\text { Disagree } \\
\mathbf{1}\end{array}$ & $\longleftarrow$ & & & $\begin{array}{c}\text { Strongly } \\
\text { Agree }\end{array}$ \\
\hline
\end{tabular}

1. Tucker County is rich in outdoor recreation resources

2. Tucker County is rich in historical resources

3. Tucker County is rich in cultural resources

4. There are strong social networks between communities in Tucker County

5. Residents get along between communities in Tucker County

6. There is a collective identity in Tucker County

7. New residents are welcomed in Tucker County

8. There is a common vision among communities for tourism in Tucker County

9. Tucker County should pursue large-scale entertainment style tourism development that will attract large numbers of visitors

10. Tucker County effectively utilizes its outdoor recreation resources for tourism

11. Tucker County effectively utilizes its historical resources for tourism

12. Tucker County effectively utilizes its cultural resources for tourism

$\begin{array}{lllll}1 & 2 & 3 & 4 & 5 \\ 1 & 2 & 3 & 4 & 5 \\ 1 & 2 & 3 & 4 & 5 \\ 1 & 2 & 3 & 4 & 5 \\ 1 & 2 & 3 & 4 & 5 \\ 1 & 2 & 3 & 4 & 5 \\ 1 & 2 & 3 & 4 & 5 \\ 1 & 2 & 3 & 4 & 5 \\ 1 & 2 & 3 & 4 & 5 \\ & & & & \\ 1 & 2 & 3 & 4 & 5 \\ 1 & 2 & 3 & 4 & 5 \\ 1 & 2 & 3 & 4 & 5\end{array}$




\section{Thoughts and Feelings about Tourism in Your Community}

Please indicate how much you agree or disagree with each statement about tourism based on the community you selected in question \#1 by circling the number that best represents your answer.

\begin{tabular}{|c|c|c|c|c|}
\hline $\begin{array}{c}\text { Strongly } \\
\text { Disagree } \\
\mathbf{1}\end{array}$ & $\longleftarrow$ & & & $\begin{array}{c}\text { Strongly } \\
\text { Agree } \\
\mathbf{5}\end{array}$ \\
\hline
\end{tabular}

1. Tourism is well developed in my community

2. My community has great potential to develop tourism

3. My community should discourage more intensive development of facilities, services, and attractions for tourists

4. There is a high quality of life in my community

5. An increase in tourism will increase the cost of living in my community

6. I support tourism development as having a vital role in my community

7. Tourism development will provide more economic opportunities for local people

8. An increase in tourism will lead to unacceptable amounts of traffic, crime, and pollution

9. Tourism development will only produce low-paying service jobs

10. I support taxes for tourism development

11. Tourism development will help to protect local resources

12. Tourism will improve the wellbeing of my community

13. The quality of public services will improve due to tourism

14. My community should invest in tourism development

15. It is important that community values are protected when tourism is developed

16. An increase in tourism will lead to crowding of outdoor recreation, historic, and cultural sites/attractions

17. Long-term planning and managed growth is important to control any negative impacts of tourism

18. My community should do more to promote its tourism assets to visitors $\begin{array}{lllll}1 & 2 & 3 & 4 & 5\end{array}$

$\begin{array}{lllll}1 & 2 & 3 & 4 & 5\end{array}$

$\begin{array}{lllll}1 & 2 & 3 & 4 & 5\end{array}$

$\begin{array}{lllll}1 & 2 & 3 & 4 & 5\end{array}$

$\begin{array}{lllll}1 & 2 & 3 & 4 & 5\end{array}$

$\begin{array}{lllll}1 & 2 & 3 & 4 & 5\end{array}$

$\begin{array}{lllll}1 & 2 & 3 & 4 & 5\end{array}$

$\begin{array}{lllll}1 & 2 & 3 & 4 & 5\end{array}$

$\begin{array}{lllll}1 & 2 & 3 & 4 & 5\end{array}$

$\begin{array}{lllll}1 & 2 & 3 & 4 & 5\end{array}$

$\begin{array}{lllll}1 & 2 & 3 & 4 & 5\end{array}$

$\begin{array}{lllll}1 & 2 & 3 & 4 & 5\end{array}$

$\begin{array}{lllll}1 & 2 & 3 & 4 & 5\end{array}$

$\begin{array}{lllll}1 & 2 & 3 & 4 & 5\end{array}$

$\begin{array}{lllll}1 & 2 & 3 & 4 & 5\end{array}$

$\begin{array}{lllll}1 & 2 & 3 & 4 & 5\end{array}$

$\begin{array}{lllll}1 & 2 & 3 & 4 & 5\end{array}$

$\begin{array}{lllll}1 & 2 & 3 & 4 & 5\end{array}$ 


\section{Social Networks and Connections}

Please indicate how much you agree or disagree with each statement by circling the number that best represents your answer. The questions are based on the community you selected in question \#1

\begin{tabular}{|c|c|c|c|c|}
\hline $\begin{array}{c}\text { Strongly } \\
\text { Disagree } \\
\mathbf{1}\end{array}$ & $\longleftarrow$ & & & $\begin{array}{c}\text { Strongly } \\
\text { Agree }\end{array}$ \\
\hline
\end{tabular}

1. I am happy to help my community

2. Residents in my community get along well together

3. I feel accepted as a valued resident of my community

4. Residents in my community assist one another in times of need

5. Different opinions are valued in my community

6. Residents in my community volunteer to support community events

7. Residents in my community trust each other

8. If I have a problem there is someone who will help

9. I feel safe in my community

10. I often do things for other residents of my community expecting nothing in return

11. There are strong social networks in my community

12. Residents in my community are involved in local organizations and informal social groups

13. Individuals and organizations in my community cooperate to achieve collective goals

14. I regularly communicate with people in my community

15. People in my community solve conflicts together

16. Residents in my community collectively participate in community events/holidays/activities

17. There is a common vision in my community

$\begin{array}{lllll}1 & 2 & 3 & 4 & 5\end{array}$

$\begin{array}{lllll}1 & 2 & 3 & 4 & 5\end{array}$

$\begin{array}{lllll}1 & 2 & 3 & 4 & 5\end{array}$

$\begin{array}{lllll}1 & 2 & 3 & 4 & 5\end{array}$

$\begin{array}{lllll}1 & 2 & 3 & 4 & 5\end{array}$

$\begin{array}{lllll}1 & 2 & 3 & 4 & 5\end{array}$

$\begin{array}{lllll}1 & 2 & 3 & 4 & 5\end{array}$

$\begin{array}{lllll}1 & 2 & 3 & 4 & 5\end{array}$

$\begin{array}{lllll}1 & 2 & 3 & 4 & 5\end{array}$

$\begin{array}{lllll}1 & 2 & 3 & 4 & 5\end{array}$

$\begin{array}{lllll}1 & 2 & 3 & 4 & 5 \\ 1 & 2 & 3 & 4 & 5 \\ 1 & 2 & 3 & 4 & 5\end{array}$

$\begin{array}{lllll}1 & 2 & 3 & 4 & 5\end{array}$

$\begin{array}{lllll}1 & 2 & 3 & 4 & 5\end{array}$

$\begin{array}{lllll}1 & 2 & 3 & 4 & 5\end{array}$

$\begin{array}{lllll}1 & 2 & 3 & 4 & 5\end{array}$




\section{I mportance and Performance of Tourism Attributes}

Please use the scale below to indicate the importance and performance of tourism attributes in your community. For example if you feel that facitlites and services for tourists are important in order to attract tourists you might rate them a 5 for importance but if you don't feel that you have enough facilties and services for tourists you might rate them a 3 for performance.

\begin{tabular}{|c|c|c|c|c|c|c|c|c|c|}
\hline $\begin{array}{l}\text { Not } \\
\text { Importan } \\
\text { t All } \\
\mathbf{1}\end{array}$ & $\begin{array}{c}\text { Somewha } \\
t \\
\text { Important } \\
\mathbf{2}\end{array}$ & $\begin{array}{c}\text { Importan } \\
\mathrm{t} \\
\mathbf{3}\end{array}$ & $\begin{array}{c}\text { Very } \\
\text { Importan } \\
\text { t } \\
\mathbf{4}\end{array}$ & $\begin{array}{c}\text { Extremel } \\
y \\
\text { I mportan } \\
\text { t } \\
\mathbf{5}\end{array}$ & $\begin{array}{c}\text { Very Poor } \\
\text { Performanc } \\
\text { e } \\
\mathbf{1}\end{array}$ & $\begin{array}{c}\text { Poor } \\
\text { Performanc } \\
\mathrm{e} \\
\mathbf{2}\end{array}$ & $\begin{array}{l}\mathrm{O} \\
\mathrm{K} \\
3\end{array}$ & $\begin{array}{c}\text { Good } \\
\text { Performanc } \\
\text { e } \\
\mathbf{4}\end{array}$ & $\begin{array}{c}\text { Great } \\
\text { Performanc } \\
\text { e } \\
\mathbf{5}\end{array}$ \\
\hline
\end{tabular}

Importance

Performance

\begin{tabular}{|c|c|c|c|c|c|c|c|c|c|c|}
\hline 1. Facilities/services for tourists & 1 & 2 & 3 & 4 & 5 & 1 & 2 & 3 & 4 & 5 \\
\hline $\begin{array}{l}\text { 2. Maintenance and management } \\
\text { of facilities for tourists }\end{array}$ & 1 & 2 & 3 & 4 & 5 & 1 & 2 & 3 & 4 & 5 \\
\hline 3. Attractions for tourists & 1 & 2 & 3 & 4 & 5 & 1 & 2 & 3 & 4 & 5 \\
\hline 4. Community leadership & 1 & 2 & 3 & 4 & 5 & 1 & 2 & 3 & 4 & 5 \\
\hline $\begin{array}{l}\text { 5. Collaboration and partnerships } \\
\text { between communities }\end{array}$ & 1 & 2 & 3 & 4 & 5 & 1 & 2 & 3 & 4 & 5 \\
\hline $\begin{array}{l}\text { 6. Collaboration and partnerships } \\
\text { with organizations outside of } \\
\text { my community }\end{array}$ & 1 & 2 & 3 & 4 & 5 & 1 & 2 & 3 & 4 & 5 \\
\hline $\begin{array}{l}\text { 7. Local and county government } \\
\text { support }\end{array}$ & 1 & 2 & 3 & 4 & 5 & 1 & 2 & 3 & 4 & 5 \\
\hline 8. State government support & 1 & 2 & 3 & 4 & 5 & 1 & 2 & 3 & 4 & 5 \\
\hline $\begin{array}{l}\text { 9. Support for entrepreneurs } \\
\text { and/or small businesses }\end{array}$ & 1 & 2 & 3 & 4 & 5 & 1 & 2 & 3 & 4 & 5 \\
\hline 10. Public support for tourism & 1 & 2 & 3 & 4 & 5 & 1 & 2 & 3 & 4 & 5 \\
\hline $\begin{array}{l}\text { 11. Public participation in decision } \\
\text { making }\end{array}$ & 1 & 2 & 3 & 4 & 5 & 1 & 2 & 3 & 4 & 5 \\
\hline 12. Skilled workforce & 1 & 2 & 3 & 4 & 5 & 1 & 2 & 3 & 4 & 5 \\
\hline 13. Community beautification & 1 & 2 & 3 & 4 & 5 & 1 & 2 & 3 & 4 & 5 \\
\hline 14. Financial investment & 1 & 2 & 3 & 4 & 5 & 1 & 2 & 3 & 4 & 5 \\
\hline $\begin{array}{l}\text { 15. Adequate public services } \\
\text { (EMS, police, fire) }\end{array}$ & 1 & 2 & 3 & 4 & 5 & 1 & 2 & 3 & 4 & 5 \\
\hline
\end{tabular}




\section{Tourism Development Options}

Please rate your thoughts and feelings toward the need for different types of tourism development activities/facilities/service in your community by indicating how much you agree or disagree with each type of tourism development option by circling the number that best represents your answer.

\begin{tabular}{|c|c|c|c|c|c|c|c|}
\hline \multirow{2}{*}{$\begin{array}{c}\text { Not Needed } \\
\text { At All } \\
\mathbf{1} \\
\text { 1. Accommodation }\end{array}$} & \multirow[t]{2}{*}{$\begin{array}{c}\text { Somewhat } \\
\text { Needed } \\
\mathbf{2} \\
\end{array}$} & \multirow[t]{2}{*}{$\begin{array}{c}\text { Needed } \\
3 \\
\end{array}$} & \multicolumn{2}{|c|}{$\begin{array}{c}\text { Very } \\
\text { Needed } \\
\mathbf{4} \\
\end{array}$} & \multicolumn{2}{|c|}{$\begin{array}{c}\text { High } \\
\text { Priority } \\
\mathbf{5}\end{array}$} & \\
\hline & & & 1 & 2 & 3 & 4 & 5 \\
\hline \multicolumn{3}{|c|}{ 2. Local Restaurants } & 1 & 2 & 3 & 4 & 5 \\
\hline \multicolumn{3}{|l|}{ 3. Chain Restaurant } & 1 & 2 & 3 & 4 & 5 \\
\hline \multicolumn{3}{|c|}{ 4. Adventure Tourism } & 1 & 2 & 3 & 4 & 5 \\
\hline \multicolumn{3}{|l|}{ 5. Nature Tourism } & 1 & 2 & 3 & 4 & 5 \\
\hline \multicolumn{3}{|l|}{ 6. Cultural Tourism } & 1 & 2 & 3 & 4 & 5 \\
\hline \multicolumn{3}{|l|}{ 7. Heritage Tourism } & 1 & 2 & 3 & 4 & 5 \\
\hline \multicolumn{3}{|l|}{ 8. Agritourism } & 1 & 2 & 3 & 4 & 5 \\
\hline \multicolumn{3}{|l|}{ 9. Festivals/Events } & 1 & 2 & 3 & 4 & 5 \\
\hline \multicolumn{3}{|c|}{ 10. Unique Local Shopping } & 1 & 2 & 3 & 4 & 5 \\
\hline \multicolumn{3}{|c|}{ 11. Chain/Big Box Shopping } & 1 & 2 & 3 & 4 & 5 \\
\hline \multicolumn{3}{|c|}{ 12. Food/Grocery Stores } & 1 & 2 & 3 & 4 & 5 \\
\hline \multicolumn{3}{|c|}{ 13. Entertainment Performance Venues } & 1 & 2 & 3 & 4 & 5 \\
\hline \multicolumn{3}{|c|}{ 14. Entertainment/ Nightlife } & 1 & 2 & 3 & 4 & 5 \\
\hline \multicolumn{3}{|c|}{ 15. Breweries/Wineries } & 1 & 2 & 3 & 4 & 5 \\
\hline \multicolumn{3}{|l|}{ 16. Bars/Pubs } & 1 & 2 & 3 & 4 & 5 \\
\hline \multicolumn{3}{|l|}{ 17. Resorts } & 1 & 2 & 3 & 4 & 5 \\
\hline \multicolumn{3}{|l|}{ 18. Theme Parks } & 1 & 2 & 3 & 4 & 5 \\
\hline \multicolumn{3}{|c|}{ 19. Golf Course/Country Club } & 1 & 2 & 3 & 4 & 5 \\
\hline \multicolumn{3}{|l|}{ 20. Casino/Gambling } & 1 & 2 & 3 & 4 & 5 \\
\hline \multicolumn{3}{|l|}{ 21. Indoor Activities } & 1 & 2 & 3 & 4 & 5 \\
\hline \multicolumn{3}{|c|}{ 22. Other (please specify) } & 1 & 2 & 3 & 4 & 5 \\
\hline
\end{tabular}

1. Accommodations

How would you define cultural tourism in Tucker County?

\footnotetext{
Do you have any additional comments about opportunities for tourism that should be pursued in your community?
} 
1. What is your Zipcode?

2. Gender

Female Male

3. Age
$18-24$
25-34
$\square 35-44$
$45-50$
$\square 51-60$
$\square 61-69$
$70+$

\section{What is the highest level of education you have completed?}

$\square$ Less than high school degree

Some college

Graduate school degree

5. What was your approximate family income from all sources, before taxes, in 2015 ?

Less than $\$ 20,000$

$\$ 60,001$ to $\$ 80,000$

$\$ 20,001$ to 40,000

$\$ 80,001$ to 100,000
$\$ 40,001$ to 60,000

$\$ 100,000+$

\section{How long have you lived in Tucker County?}
1 year or less
$\square$ 2-5 years
6-10 years
11-15 years
16-20 years
$\square$ 21-30 years
$31-40$ years
41 or more years

7. Where did you live before moving to Tucker County?

8. If you moved to Tucker County from somewhere else why did you move?

9. Do you own or rent your home? $\square$ Own $\square$ Rent

10. What is your role in the community? (please check all that apply)

$\square$ Government official

$\square$ Local or county board, commission, authority

$\square$ Non-profit organization (please specify

$\square$ Tourism-related business owner $\square$ Non-tourism related business owner

$\square$ Employed by tourism (please specify employer

Non-tourism related employment (please specify employer
Resident
Part-time Resident
Second home owner

Other (please specify

Please list any groups or associations in Tucker County that you volunteered with, worked for, or otherwise supported in Tucker County within the past 12 months 
What does tourism mean to you?

How can tourism benefit you personally?

What values do you feel are important in your community?

How would you define the culture of Tucker County?

The most attractive features of your community include:

The most unattractive features (if any) of your community include:

Are there any places in Tucker County where you do not want tourists?

$\square$ Yes $\square$ No

If yes, please list:

Do you have any additional comments about this survey or tourism in Tucker County?

If you would like to enter the prize raffle please proceed to the next page. 
Upon completion of the survey you may enter a drawing to win a summer 2016 family float trip with Blackwater Outdoor Center, 2 tickets to a West Virginia Black Bears baseball game, or two tickets to a WVU Men's Basketball game by entering your contact information below. You must complete the survey and enter contact information below to participate in the prize drawing so that we can contact you if you are the winner. This information will be recorded separately from the survey and not connected to your survey responses in any way.

Name:

Address:

Email or Phone:

Thank you once again for your time and support for this study. 